\title{
Restoring riffle-pool structure in an incised, straightened urban stream channel using an ecohydraulic modeling approach
}

John S. Schwartz*1 ${ }^{1}$, Keil J. Neff ${ }^{2}$, Frank E. Dworak ${ }^{3}$, and Robert R. Woockman ${ }^{4}$

* Corresponding Author

${ }^{1}$ Associate Professor; University of Tennessee, Department of Civil and Environmental Engineering; 413 John D. Tickle Engineering Building, Knoxville, Tennessee 37996; Phone (865) 974-7721; Email: jschwart@utk.edu

${ }^{2}$ Senior Project Engineer; Geosyntec Consultants, 2240 Sutherland Avenue, Knoxville, Tennessee 37919; Phone (865) 330-0037; Email: kjn.water@ gmail.com

${ }^{3}$ Hydraulic Engineer; US Bureau of Reclamation, 6th \& Kipling, Building 67, Denver, Colorado 80225; Phone: 303-445-2547; Email: fdworak@usbr.gov

${ }^{4} \mathrm{PhD}$ Graduate Research Assistant; University of Tennessee, Department of Civil and Environmental Engineering; 411 John D. Tickle Engineering Building, Knoxville, Tennessee 37996; Email: rwoockm@utk.edu 


\section{ABSTRACT}

Streams in urban and urbanizing watershed are impacted by altered watershed runoff hydrology and sediment yields, floodplain modifications, and constrained channel planform. One morphological response to these urbanization impacts is the degradation of pool-riffle sequences. Pools and riffles are fundamental mesohabitat units where many lotic biota have evolved to occupy preferentially. Restoring self-maintaining pool-riffle structures is essential to the ecological rehabilitation of urban streams when lost. However restoring these structures can be problematic after a stream has been straightened from prior land development, and current civil infrastructure preventing channel re-meandering. Project goals included: 1) developing a conceptual restoration design by applying geomorphic and three- and two-dimensional hydraulic principles, focusing on flow acceleration and deceleration zones to maintain pool-riffle structures in a straight channel, 2) using River2D, a two-dimensional hydrodynamic model as an ecohydraulic tool to design a pilot project on Beaver Creek, Knox County, Tennessee, and 3) constructing the designed project with follow-up preliminary monitoring and assessment. Ecological information was integrated into the design process from pre-construction monitoring of fish communities, and application of the aquatic habitat module in River2D, utilizing habitat suitability curves (velocity, depth, and substrate) for three fish species. River2D also provided estimates on spatially-distributed shear velocities aiding the design process, which were used for examining channel and bank stability, and placement of root wads. Construction of four poolriffle structures on Beaver Creek was completed in March 2012. A geomorphic survey was completed in April 2013, in which the constructed riffle structures have remained stable even with the project site experiencing eight bankfull events. Post-construction monitoring has shown 
that the unique design for planform-constrained urban channels has promise for increasing hydraulic habitat diversity and improving ecological integrity in these stressed environments.

Keywords

Urban streams

Stream restoration

Ecohydraulics design

River2D model

Riffle-pool habitat

Channel incision 


\section{Introduction}

Streams in urban and urbanizing watersheds are impacted by hydromodification and channelization which degrade macro-bedform structure providing essential habitat for aquatic biota (Booth and Jackson, 1997; Wang et al. 2001; Fitzpatrick et al. 2004; Walsh et al., 2005a; Bernhardt and Palmer, 2007). Hydromodification from increased impervious surfaces result in higher peak flows, greater runoff volumes, and decreased summer baseflows compared with unaltered streams (Paul and Meyer, 2001; Jennings and Jarnagin, 2002; Annable et al., 2012). Channel relocation and straightening often occurs during watershed urbanization, and as urban development density increases channel planform becomes constrained (Morris and Moses 1999; McBride and Booth, 2005; Kang and Marston, 2006). In addition, pre-urbanization channelization is typical in the Appalachian region from agricultural practices to increase valleybottom utilization and improve drainage. These physical changes from urbanization and channelization have been documented to cause channel incision, a deepening and widening of the morphology, and a loss of riffle-pool sequences (Simon and Hupp, 1990; Gregory et al., 1994; Simon, 1995; Bledsoe and Watson, 2001; Cianfrani and Hession, 2006; Colosimo and Wilcock, 2007). Loss of riffle-pool sequences severely degrades stream habitat quality and ecological function, and restoring stable riffle-pool structures must be a primary objective in stream restoration design (Emery et al., 2003; Shields et al., 2003; Sear and Newson, 2004; Schwartz and Herricks, 2007).

Riffle-pool sequences are fundamental habitat structures in which stream communities have ecologically evolved to partition resources and function, i.e., feeding, reproduction, and predation and hydraulic refugia (Mathews 1990; Aadland. 1993; Newson and Newson, 2000; Schwartz and Herricks, 2005, 2008). As an expression of their life histories, fish and benthic 
macroinvertebrates have specialized to occupy pool and riffle habitat space, occurring across multiple ecoregions in the US (Lamouroux et al., 2002; Poff et al., 2006; Schwartz et al., 2011). Stream restoration efforts should include self-maintaining riffle-pool morphology to provide habitat structure for a diverse community of biota that can fulfill their life histories (Rabeni and Sowa, 1996; Schwartz, 2002; Clifford et al., 2006). Achieving self-maintaining riffle-pool structure is problematic when geomorphological processes are influences by the effects of urbanization (Harper et al., 1998; Walsh et al., 2005b; deAlmeida and Rodriguez, 2011).

In natural alluvial channels, riffle-pool morphology is self-maintaining when adequate bedload sediment supply is transported and deposited by local hydraulics, in which the morphological structure is in dynamic equilibrium with channel forming flows (Hey and Thorne, 1986; Clifford, 1993; Sear, 1996; Knighton, 1998). It is generally recognized as the 1.5- to 2year return frequency that maintains the channel geometry, with riffle cross-sectional areas being wider and shallower than pools, and longitudinally riffle spacing equal to 5 to 7 channel unit widths (Richards, 1976; Keller and Melborn, 1978; Gregory et al., 1994; Millar, 2004; Johnson and Frecko, 2008). Several geomorphological processes have been suggested as key principles for the development and maintenance of riffle-pool structures. Locally, it is during flood flows that create the hydraulics so that pools are scoured and bedload is deposited in the riffle areas, which is commonly known as the velocity or shear stress reversal hypothesis (Lisle, 1979; Keller and Florsheim, 1993, Carling, 1992; Cao et al., 2004; Wilkinson et al., 2004). Flow resistance from bed and banks, and associated macro-bedform structures influence local hydraulics and scale patterns of turbulent structures. Both straight and meandering channels without excessive in-stream structural elements form helical flow patterns from boundary conditions and flow resistance, creating self-maintaining morphological processes for bar unit structure (Dietrich, 
1987; Rhoads and Welford, 1991; Frothingham and Rhoads, 2003). Banks vegetation influences reach-scale hydraulic patterns and turbulence scaling, which affects riffle-pool maintenance processes and overall channel stability (Rhoads et al., 2003; Hession et al. 2003; Simon and Rinaldi, 2006; Clark and Wynn, 2007). Yalin (1992) recognizes the key influence of flow resistance from the bed boundary and further integrates turbulent flow structures scaling to channel depth, as an explanation to riffle-pool sequence development and self-maintenance.

The question remains whether these critical geomorphological processes that have been observed in minimally disturbed watersheds can be applied in urban streams such that a newly designed morphology can sustain fundamental processes and form. In general, multidimensional channel hydraulics has not been applied in stream restoration practice today, mostly relying on an anti-log reference reach approach (Neizgoda and Johnson, 2005). Conflicting assessments of the reference reach approach for stream restoration has been discussed (Slate et al., 2007; Simon et al., 2007; Rosgen, 2008). In urban streams under the influence of hydromodification, this approach can be problematic due to the fact streams are not in dynamic equilibrium. Because of hydromodification, an ecological engineering approach is necessary to improve ecological integrity of urban streams, noting that the return to a pristine is not possible (Schwartz et al., 2001). In urban streams, grade controls have been shown to be effective in reducing incision (Bledsoe et al., 2012), and it is common to use various weir structures for the hydraulic control (Rosgen, 1996; Niezgoda and Johnson, 2006). In low-gradient streams, weir structures can create pools, but not riffles where there height can cause an upstream backwater. The riffle substrate is critical for habitat, and an alluvial veneer at that bedform must be stable during periodic bankfull flow events annually. Hydraulic modeling studies have improved our understanding of the processes, and can be a valuable tool to test ideas on newly designed riffle 
structure and incorporate ecohydraulics concepts (Shamloo et. al., 2002; Bockelmann et al., 2003; Booker et al., 2003; Booker and Dunbar, 2004; Smith and Prestegarrd, 2005). The restoration challenge in low-gradient urban streams under the impact of hydromodification is to develop a stable riffle-pool structure where meandering into a historic floodplain is not possible.

As a case study, the goal of this paper is to describe an ecohydraulic design process developed to restore self-maintaining riffle-pool structures in a straightened, incised urban stream constrained by civil infrastructure where channel planform could not be modified. The specific objectives of this study were to: 1) assess geomorphic concepts for self-maintaining riffle-pool sequences utilizing multi-dimensional hydraulic models, 2) utilize ecological data and integrate that data into a hydraulic modeling design process; and 3) from a newly proposed rifflepool design, construct a field-scale structure and assess stability and biological integrity.

\section{Study Area}

\subsection{Study Site Description}

The study site included a 270-m reach of Beaver Creek located in Knox County, Tennessee (Fig. 1). The watershed lies in the Ridge and Valley physiological providences, forming a trellis drainage pattern. The drainage area is $39 \mathrm{~km}^{2}$ consisting of $14.2 \%$ urban land use (residential, commercial, and industrial) based on the 2006 National Land Cover Database. In general, the upper Beaver Creek watershed has been urbanized concurrently with the overall metropolitan growth of Knoxville. Historically, the stream was channelized when the adjacent land was used for dairy production with local residents indicating channelization occurred in the 1930s, but no direct evidence was obtained on an exact date.

The channel has incised over the past decade likely due to flow modification from urbanization, as evidenced by the tree truck curvature (Fig. 2). The 6.5-m wide channelized 
reach has an average slope of $0.0001 \mathrm{~m} / \mathrm{m}$, and bank and bed consists of cohesive soils. Trees line the channel on both banks and impede flows greater than $1.7 \mathrm{~m}^{3} / \mathrm{s}$. Bankfull flow was approximated at $4.0 \mathrm{~m}^{3} / \mathrm{s}$, defined as the stage overtopping top of bank. A continuously recording stage recorder (GlobalWater ${ }^{\mathrm{TM}}$ WL400) has been installed on site since August 2009. Mass bank-failures have not yet occurred due to the cohesive property of the soil in this region, and the elaborate root systems of the vegetation lining the banks. The original study reach had diminished pool-riffle bed morphology, with the habitat structure consisting mostly of long glides and local scour pool adjacent a large bank root mass.

The straight channel is bordered on the west with a Food City grocery store and parking lot, and on the east bank with a paved greenway. The Knox County Parks and Recreation Department manages the greenway. At the end of the study reach protecting a pedestrian bridge to the greenway is a rip-rap rock grade control across the channel. Both sides of the channel were constrained with urban development, including buried optical communication lines preventing a stream restoration approach utilizing planform modification, i.e., meandering.

\subsection{Geomorphic and Biological Site Data}

Bed and bedload sediment sizes and bank critical shear stress $\left(\tau_{\mathrm{c}}\right)$ were geomorphic data needed to support the restoration design process. The project reach incised into cohesive material, with the bed covered by thin-veneer patches of sand and fine gravel mixtures. The $\mathrm{D}_{50}$

of the bed sediment per standard pebble count was measured as $6 \mathrm{~mm}$ (Cantrell, 2009). Cantrell (2009) also measured bedload transport with Bunte et al. (2004) net traps, in which the transported material was measured as $1.4-\mathrm{mm} \mathrm{D}_{50}$ and $18-\mathrm{mm} \mathrm{D}_{\max }$ and generally observed as supply-limited. The results of these measurements indicated that the design must include specifying the placement of gravel substrate for the new riffles. Sediment transport data are 
needed for urban streams because of hydromodification and potential for bedload supply to be reduced from headwaters modified with urban infrastructure (i.e., drainage piping and culverts, and stormwater detention BMPs). A critical shear stress for the cohesive bank material was needed in the design process to identify potential locations where excessive erosion could compromise channel stability. A $\tau_{\mathrm{c}}$ was determined by a Hanson et al. (1990) jet test device as 3.8 Pa (Mallison, 2008). This $\tau_{\mathrm{c}}$ was used to compare with $\tau_{0}$ estimates from the $2 \mathrm{D}$ hydraulic model for bankfull discharge to spatially identify locations that may need scour protection.

Biological data included previous surveys for benthic macroinvertebrates and fish. Benthic macroinvertebrate data identified a system classified as water quality impaired from "siltation" and habitat alternation, where Beaver Creek at the study site was placed on the state 303(d) list. Williams (2005) states a Tennessee Macroinvertebrate Index (TMI) score of 28 (TMI range 042), which is considered partially impaired by state water quality statues. Fish Indices of Biotic Integrity (IBI) were found to be with the Beaver Creek watershed ranged from 27 to 50 (IBI range 0-60), and were indirectly correlated with percent urban land cover (Sain, 2006). In general, Sain (2006) found healthy fish communities as source areas for reestablishment of degraded reaches, including many intolerant species from families Centrarchidae, Cyprinidae, and Percidae. Prior fish surveys indicate that restored riffle-pool habitat would benefit the biotic integrity of the study reach at Halls Crossing.

\section{Development of a Riffle-Pool Design for Urban Stream Restoration}

Development of a riffle-pool design for urban stream restoration, where a meander planform cannot be constructed due to civil infrastructure constraints required the use of hydraulic models. Three- and two-dimensional (3D, 2D) hydraulic models were used to observe the influence of bank vegetation on reach-scale helical flow patterns and longitudinal development of 
deceleration-acceleration zones at riffle-pool sequences, and shear-stress reversal for riffles and pools between low- and high-flow stages. Design development also included the application of mass continuity were increased channel cross-sectional area would decrease average velocity. Understanding flow resistance from tree-lined banks, and the potential role they may play in riffle-pool maintenance was particularly important in developing a stream restoration design strategy for the Appalachian region (Fig. 2).

The proposed conceptual design to be qualitatively assessed by a hydraulic modeling effort consisted of removing trees at a laterally expanded channel area to form a deceleration zone, and maintaining the narrow tree-lined channel to promote acceleration during high-flows (Fig. 3). Within the context of the proposed design, several geomorphic questions were posed and investigated through modeling, which were: 1) does tree bank vegetation and the scaling of turbulence structure to bank trees prevents development of reach-scale helical flow patterns? 2) can acceleration-deceleration zones be created with alternating high- and low-resistant sections of stream, relative to each other as tree-lined and not? 3) can deceleration zones be accomplished at constructed riffles through channel expansions based on continuity concepts? 4) how important is the entrance slope into a riffle structure in the energy dispersion to prevent local scour? and 5) do we observe velocity/shear stress reversal from low- to high flow?

In addition to assessing whether 2D- and 3D-model hydraulic patterns from the proposed riffle-pool structure were consistent with published geomorphic theories on maintenance processes, this case study illustrated the use of these models in an ecohydraulic approach to stream restoration. Ecological criteria are incorporated into the modeling effort by utilizing a PHABSIM approach (Ghanem et al., 1996; Schwartz, 2003; Booker and Dunbar, 2004). By 
example, this case study provides a design framework for urban streams integrating fluvial geomorphology, hydraulics, and ecological concepts.

\subsection{Geomorphic Concepts and Hydraulic Model Design Simulations}

\subsubsection{Influence of Bank Trees on Reach-scale Hydraulic Patterns}

Background. Many theories and geomorphic process mechanisms support why riffle-pool sequences are maintained in alluvial streams (Knighton, 1998). Sequences commonly occur between 5 to 7 channel unit widths in succession in both straight and sinuous channels, and are strongly influenced by cross-sectional width to depth ratios (Keller and Melhorn, 1978, Dietrich, 1987; Gregory et al., 1994). Development and maintenance processes involve the hydrodynamics of sediment transport in the channel, and scaling of turbulence structure to form the oscillating patterns of bed deposition and scour (Yalin, 1992; Clifford, 1993). In straight channels, Yalin's (1992) theoretical explanation of riffle-pool sequence development is based on macroturbulent flow scaling and his eddy bursting process envisages alternating regions of highand low-speed flow layers. Bursting scaled to the water depth creates "sweep" velocity vectors orientated towards the bed inducing scour and sets up a feedback loop of continued scour sequencing at approximating 6 flow depths. No one theory explains the riffle pool formation, but observations and modeling has illustrated the importance of acceleration-deceleration patterns, and longitudinal flow alternating convergent-divergent patterns (Thompson, 1986; Rhoads and Welford, 1991). Convergent-divergent flow, combined with secondary circulation currents form helical patterns where surface flow convergence occurs at pools increasing bed shear and inducing scour during high flows, and at riffles flow convergence occurs at the stream bed reducing shear and favoring sediment deposition (Lane et al., 1998). Because the downstream velocity is greatest compared to the secondary circulation, a helical flow pattern is 
theoretically maintained (Frothingham and Rhoads, 2003). However most modeling and field measurements have been conducted on channels without excessive bank resistance, which is observed in Appalachian streams. In general for most streams, it is agreed that once formed, riffle-pool morphology controls hydraulic patterns, which in turn control bed scour, sediment transport and sorting playing a key role in equilibrium dynamics of channels (Heritage and Milan, 2004). Another fundamental hydrogeomorphic process is the velocity- or shear-reversal hypothesis which explains the patterns of scour and deposition, and overall maintenance of the macro-bedform (Keller and Florsheim, 1993, Cao et al., 2002; Rodríguez et al., 2008). This hypothesis suggests that at low-flow stages higher velocities and shear stress relative to the pool moves fine sediments, and during high-flow stages velocities and shear stress scour pools, and tend to lend to sediment deposition over the riffle. This sediment sorting process maintains this bedform. Dietrich (1987) explains this description of the sorting process and transport of sediment through a bar unit, consisting of a bar-riffle-pool structure in meandering channels.

Method. CFD model simulations were completed, in order to characterize flow structures during bankfull stage to examine the influence of tree-lined banks on flow resistance and reachscale hydraulic patterns (Dworak, 2005). FLOW-3D ${ }^{2}$, a commercial three-dimensional CFD model, with a graphical user interface was utilized to generate reach simulations. It is comprised of a pre-processor, finite element mesh generator, and a post-processor for display of simulations. Study site topography was surveyed with a Trimble Total Station and Recon Data Logger, extending $105 \mathrm{~m}$ from the study site start shown on Figure 1, and topography and tree locations were imported as ASCII formatted x-y-z files into FLOW-3D® (Fig. 4). Trees along banks were generated as subcomponents in the model and represented as symmetric vertical cylinders; measured diameters were used for the 102 trees accommodating both banks. A 3D 
finite element grid was generated for the entire flow field. The discharge simulated was 1.68 $\mathrm{m}^{3} / \mathrm{s}$, in which trees on both banks begin to impede flow. Within the Navier-Stokes governing equation, including Reynolds stresses, the turbulence closure scheme chosen for model simulations was the k- $\varepsilon$ model. The roughness height coefficient " $k$ " was computed by a FLOW3D ${ }^{\circledR}$ algorithm that utilizes hydraulic radius and a selected Mannings $n$ of 0.019. Initial conditions for the upstream boundary were a flow depth of 1.72 meter and a velocity per grid cell of $0.4 \mathrm{~m} / \mathrm{s}$. Steady-state conditions were modeled for simulation output, in which model stability was achieved over simulation time.

Model scenarios included: 1) incised channel with bank trees generating large-scale roughness, the existing condition of the study site; and 2) incised channel, where bank tree clusters were spaced 5-7 channel unit widths to create acceleration-deceleration flow patterns, a model modified condition. Dworak (2005) also modeled a scenario in the incised channel without bank trees, where bank roughness is a function of boundary morphology, a model modified condition. Full details of the FLOW $3 \mathrm{D} \otimes$ model set-up, boundary conditions, and model performance parameters can be found in Dworak (2005).

Results. FLOW3D $®$ model results presented here within include cross-sectional velocities along a longitudinal sequence for the two scenarios defined above. The datum for the longitudinal distances along the 105-m modeled reach starts with zero at the downstream boundary. Velocity vectors near bank trees were pronounced representing flow deflection, and forming vortices immediately downstream of the tree (Fig. 5). In most cross-sections, the downstream velocity vectors dominate in the mid-channel with near-bank vectors scaling to tree or boundary roughness. Cross-sections at longitudinal distances $59.90 \mathrm{~m}$ and $55.03 \mathrm{~m}$ show development of channel-scale secondary flow vectors, and again at distance $49.62 \mathrm{~m}$. A 
noticeable immediate depression in the streambed at longitudinal distance $45.84 \mathrm{~m}$ of the channel caused downward directed vectors. Large-scale heterogeneity in bed-topography, such as channel morphology and ledges within the streambed, and the presence of trees on the banks appears to prevent the development of helical flow patterns along the modeled channel length. Scaling of turbulence structure near the trees is evident in additional modeling output in Dworak (2005), where the dissipation rate per unit mass of turbulent kinetic energy (TKE) exceeded 0.01 $\mathrm{J} / \mathrm{kg}$-s downstream of trees impeding flow. Results illustrate the potential for flow resistance and reach-scale turbulence structures to be heavily influenced by the bank trees, suggesting their influence on riffle-pool maintenance hydraulics must be considered in restoration design. It needs to be noted that this model was not verified with field measurements, but in general CDF results do provide qualitative results showing the importance of bank resistance properties and the influence on reach-scale hydraulic patterns. It also provided the template to explore whether modifying bank resistance patterns could be utilized as a potentially useful design practice.

In order to examine the influence of sequencing bank roughness, a modeling scenario removed the tree (cylinders) on both banks from longitudinal distances approximately $30 \mathrm{~m}$ to 58 $\mathrm{m}$ and $75 \mathrm{~m}$ to $96 \mathrm{~m}$. Cross-sectional velocities along a longitudinal sequence from FLOW3D ${ }^{\circledR}$ model were plotted for the same distances as with all trees modeled (Dworak, 2005). Per visual inspection, development of reach-scale secondary flows appeared to occur with the potential for helical patterns (Fig. 6). At longitudinal distance $79.85 \mathrm{~m}$, secondary flow vectors appear orientated "left", followed by two circulation cells with converging vectors at the water surface at distance $77.09 \mathrm{~m}$, and a reversal of secondary flow at $60.17 \mathrm{~m}$ to the "right". The same downward directed velocities as observed in Figure 5 due to a bed slope drop is observed in Figure 6 under this modeling scenario. Model results do suggest that modifying bank roughness 
sequentially may induce secondary flow circulation possibly supporting riffle-pool maintenance flow patterns. Further research is needed to investigate this hydraulic phenomenon, however for the purpose of supporting a riffle design for straight urban streams it will be incorporated as one applied concept.

\subsubsection{Influence of Channel Width Expansions and Riffle Incline Slope on Hydraulic Patterns}

Background. In order to examine the influence of channel width expansions and riffle incline slope on hydraulic as potential design elements, River2D was used. River2D utilizes twodimensional (2D), shallow-water, depth-averaged Saint Venant equations conserving mass and momentum through an unstructured finite element mesh (Steffler and Blackburn, 2002). As a high-resolution scheme, the River2D model allows freely intermixed subcritical and supercritical flow without the imposition of artificial eddy viscosity. For computational stability, finite element solutions are based on the Streamline Upwind Petrov-Galerkin weighted residual formation (Ghanem et al., 1996). River2D has wetting-drying capability on banks utilizing groundwater flow equations and transmissivity. River2D output includes plots per finite element cell for velocity, water depth, water surface elevation, Froude number, and shear velocity (Schwartz and Neff, 2011).

Applying continuity for steady-flow for a River2D model scenario by expanding the channel width at four proposed riffle locations assessed the influence of gradual channel expansions on flow deceleration (Fig. 3). The basic concept is discharge is constant and a function of crosssectional average (V) velocity times area (A), thus increasing by A, V must decrease (Sturm, 2010). The original topography could be modified by expanding channel width until sufficient deceleration is achieved for a stable riffle. In this case, the project site was planform-constrained so the question became what were the reduced riffle velocities for the maximum allowable 
channel width that did not interfere with existing civil infrastructure. In addition to creating deceleration-acceleration patterns at riffle-pool sequences, River2D model simulations were used to observe whether bed shear stress reversal occurred from low-flow to high-flow stages, fundamental to sequence maintenance.

Specific to the influence of the riffle entrance incline slope, Yang (1971) hypothesized that channel forms in equilibrium with a minimum energy dissipation rate, governing the periodic pattern of sediment transport and deposition along a longitudinal transect with riffle-pool bedforms. This suggests that the riffle entrance slope incline creates converting flow paths in the vertical enhancing turbulence and increasing energy dissipation rates. Qualitatively, a stable riffle design should include energy dissipation reducing local high-velocity flow paths, such as a thawleg "jet".

Method. Comparisons among River2D model scenarios were used to address questions on the development of the conceptual design for a stable riffle in a straight, incised urban channel. With River2D, the entire project reach, $270 \mathrm{~m}$ in length was used in model simulations, based on the site topography survey (Fig. 1). River2D modeling procedures were followed as described in Steffler and Blackburn (2002). A $4 \mathrm{~m}^{3} / \mathrm{s}$ discharge was used for bankfull conditions, and 0.5 $\mathrm{m}^{3} / \mathrm{s}$ was used for low-flow conditions.

Modeling efforts included: 1) water depth and velocity comparison of the original channel morphology to the designed channel with expanded widths at riffles, without entrance slope modifications; 2) water depth and velocity comparison of expanded channel widths at riffles without entrance slope modifications to same lateral morphology but added a pre-riffle pool to increase the riffle entrance incline slope; and 3) shear velocity comparison between low- and 
high-flows for the designed channel with expanded width areas and entrance pools in order to assess shear stress reversal.

Results. The original topography was modeled for high- and low-flows in order to illustrate the lack of flow acceleration-deceleration zones and riffle-pool sequences (Fig. 7). In general terms, River2D model results showed a high-velocity core mid-channel, with lower velocity very near the banks. River2D could not fully capture the effect of the tree-lined bank, but was addressed in the model by increasing the roughness height $\left(\mathrm{k}_{\mathrm{s}}\right)$ compared with the channel bed. Water depth at low-flow stage remained relatively constant along the thawleg between 0.4 and $0.6 \mathrm{~m}$, lacking riffle-pool features. One deep pool occurred near the upstream end of the modeled reach that was approximately $0.85 \mathrm{~m}$ in depth.

The initial modeling scenario did not modify the bed topography at the entrance of the proposed riffles (Fig. 8). Model results showed deceleration overall from the upstream and downstream narrower channels; however high-velocity jets extended into riffle thawlegs. This model result indicated by just expanding the channel width alone does not completely lead to full cross-sectional flow deceleration over the riffle. By having a high-velocity jet entering the riffle concentrated mid-channel, it was believed that this could lead to an unstable riffle bed by preferential erosion spatially.

The next River2D modeling scenario consisted of deepening the bed topography at the riffle entrance with the idea that this would cause converging flow paths, increasing turbulence and energy dissipation. The change in bed elevation pre-riffle to riffle for initial design with no bed modification was between 0.1 to $0.2 \mathrm{~m}$ (Fig. $8 \mathrm{a}$ ), whereas for the final design with bed modification the change in bed elevation was approximately $0.45 \mathrm{~m}$ (Fig. 8b). The slight deepening of the bed pre-riffle was sufficient enough to reduce the pronounced high-velocity jet. 
Additional depth could improve energy dissipation further, but in general this modeling exercise illustrated the importance of riffle entrance incline slope per deeper pre-riffle pool.

Finally, the River2D model was used to investigate velocity and shear stress reversal by shear velocity $\left(\mathrm{u}_{*}\right)$ as the model output parameter for low- and high-flow stages. Per visual inspection, it is apparent with the final channel design with expanded widths at riffles and preriffle pools, bed shear stress reversal occurs (Fig. 9). During the low-flow stage, $u *$ was greater in the riffles than the pools, approximately $0.05-0.08 \mathrm{~m} / \mathrm{s}$ and $0.03 \mathrm{~m} / \mathrm{s}$, respectively. During high-flow stage, $\mathrm{u} *$ was greater in the pools than the riffles, approximately $0.08-0.10 \mathrm{~m} / \mathrm{s}$ and $0.04-0.07 \mathrm{~m} / \mathrm{s}$, respectively.

In addition to justifying riffle-pool maintenance flows, spatial mapping of $u_{*}$ provides estimates to compare with critical bed/bank shear stresses $\left(\tau_{\mathrm{c}}\right)$ through field measurements or can be used to size gravel material for the riffle and locate bank areas that need armoring. Per River2D model output inspection, the maximum $\mathrm{u}_{*}$ on the bed and bank were $0.135 \mathrm{~m} / \mathrm{s}$ and 0.08 $\mathrm{m} / \mathrm{s}$, equating to a bed shear stress $\left(\tau_{0}\right)$ of $18.2 \mathrm{~Pa}$ and $6.4 \mathrm{~Pa}$, respectively (Fig. 9). The measured $\tau_{\mathrm{c}}$ from the jet tester device was 3.8 Pa, indicating some locations on the bank need scour protection. These vulnerable locations required engineering judgment by either 1) modifying the design morphology, and/or 2) incorporating a root wad structure into the bank at potentially erosive bank locations. The maximum $\tau_{0}$ from the River2D model for the riffle bed was $18.2 \mathrm{~Pa}$, which was used to design the riffle gravel size to be imported for the project. Using the Shields diagram, this $\tau_{0}$ was used to size the riffle material imported for construction, where the minimum gravel diameter of $2.5 \mathrm{~cm}$ was estimated (Sturm, 2010). The final project gravel size specified was $3.8 \mathrm{~cm}$ diameter. The shear velocity plot is a key tool for the checking stream restoration design for local channel stability, and estimating imported rock size on the streambed. 


\subsubsection{Ecohydraulic Modeling Approach to Support Restoration Design}

Background. River2D incorporates a habitat module using PHABSIM methodology which computes weighted usable areas (WUAs) per stream surface area (Bovee et al., 1998). WUAs are based on a combination of hydraulic (velocity and depth) and substrate conditions, multiplied by the composite probability of use by fish or other aquatic biota. Probabilities are referred to as habitat suitability indices (HSI) and are associated with species' habitat quality preferences for velocity, depth, and substrate type. The River2D hydraulics module provides the habitat module with water depth and depth-average velocity per finite element cells. Two additional input files are needed to run the habitat module; they are the channel index file defined by the user a numeric code for substrate types (e.g., clay/silt $=1$, sand $=2$, gravel $=3$; cobble $=4$; bank cover $=6$, and rock $=7)$. A second file is HSI species preferences ranging from 0 to $1(0=$ no preference, $1=$ full preference). Fish HSI are typically obtained through field studies using prepositioned areal electrofishing devices (Schwartz and Herricks, 2004; Zale et al., 2013). If not collected individually, HSI data can be found in reports from the U.S. Fish \& Wildlife Service, Instream Flow Incremental Methodology (IFIM) studies by power companies and consulting firms, and various other sources.

Method. WUAs were compared for the original channel and final design morphologies, with the final design per Figure 9 topography. WUAs were computed for three fish species to best assess the influence of adding riffle-pool structures, and for low- and high-flow discharges of 0.5 $\mathrm{m}^{3} / \mathrm{s}$ and $4.0 \mathrm{~m}^{3} / \mathrm{s}$, respectively. The fish species included rock bass (Ambloplites rupestris) a pool-orientated species, greenside darter (Etheostoma blenniodes) a riffle-orientated species, and northern hogsucker (Hypentelium nigricans) a habitat generalist, all of which per Sain (2006) reside in the Beaver Creek watershed. HSI relationships for velocity, depth, and channel 
substrate for these three species were obtained from Payne (2008), in which field studies were conducted in the Appalachian region.

Results. WUAs increased from the original channel to the designed channel for both low- and high-flow stages, and all fish, expect for rock bass at low-flow stages (Table 1). The greatest increase in WUAs was for the greenside darter, which correlates with the added riffles structures not present in the original channel (Fig. 10). One must caution the interpretation of the results, in that model WUAs only include the available habitat not that a fish species will occupy quality habitat. River2D is a useful tool to examine how a proposed design morphology may influence improvement of habitat conditions relatively, and locate areas to improve habitat quality by additional channel morphology modifications. This process constitutes the ecohydraulic component of the overall stream restoration design process. Per Table 1, River2D results indicate rock bass habitat, as pool habitat could be added to the design. Another interpretation from the results illustrated how the new riffle structures could provide the northern hogsucker with high-flow refugia (Fig. 11). Overall this design process remains qualitative, in that the model generates WUAs showing relative improvements from a proposed design, but knowing what the target WUAs should be requires further species-specific research.

\subsection{Ecohydraulic Design Integration}

The initial restoration design process included the application of geomorphic and hydraulic principles to develop a riffle-pool structure that would be stable in a straight planform and impacted by urban hydromodification (annual exceedence of 1-2 bankfull events). Riffle-pool morphology are significant habitat features because stream biota have evolved and developed life histories to specifically exploit the necessary resources for survival per habitat space (Aadland, 1993; Poff et al., 1997; Schwartz, 2002). The pre-construction design was assessed by various 
hydraulic model simulations, suggesting that the concept utilizing an expanded channel width for new riffles and a pre-riffle pool would create flow deceleration during high flows for riffle maintenance. Preserving the existing narrow channel with bank trees would promote flow acceleration for pool maintenance. Riffles provide habitat for benthic macroinvertebrates, the

food generators for various omnivore and insectivore fish species. Riffles within $2^{\text {nd }}-$ to $3^{\text {rd }}$-order streams commonly will form leaf packs at larger rocks or wood, providing their food source (Vannote et al., 1980; Allen and Castillo, 2007). Ecologically, the proposed riffle design included placement of gravel as sized per hydraulics (Section 3.3.2), and larger-sized cobble for leaf pack development and ecosystem enhancement.

The ecohydraulic design approach considers biological needs at multiple flow stages, and can be applied by PHABSIM technique in the River2D model. The channel morphology at low-flow stages creates swift water over gravel the riffles, whereas the pools provide the majority of rearing habitat for species in the Beaver Creek watershed (Sain, 2006). Channel morphology at high-flow stages must provide refugia as a flood event passes, and as shown in Figures 8 and 11, the new riffle design provides that refugia. High-flow refugia are found in lateral hydraulic recirculation zones (Schwartz and Herricks, 2005). The key design approach is to provide hydraulic habitat diversity, which by ecological theory sustain a more diverse and healthy ecosystem (Allen and Castillo, 2007).

\section{Project Construction}

The final riffle-pool design for the 270-m reach consisted of four riffle structures aimed with a riffle spacing of 35-49 m, based on the criteria of 5-7 bankfull widths. However, the available vertical drop in the low-gradient reach presented a design constraint so that a backwater one riffle did not reach the adjacent upstream riffle. With the overall gradient and a 7-cm drop across 
the riffle, four riffles could be fitted into the project reach. Riffle locations were selected based on bank tree configurations utilizing existing trees as bank protectors at the channel constraint following the riffle expanded width area (Fig. 12). Geolift bank were constructed with coir matting and native soils at 3:1 side-slopes, and planned with willow stakes. Locations with excessive shear stress, as identified from the River2D model output were designed with root wads. On-site trees were used for the root wads. Within the riffle bed, $3.8 \mathrm{~cm}$ stone was placed for the alluvial veneer layer approximately $15-20 \mathrm{~cm}$ thick. Rock $12-18 \mathrm{~cm}$ in diameter was placed on the riffle stone, spaced 1-2 m apart to create the structure for leaf pack generation (Fig. 13). Project construction began in October 2010, and was completed March 2011.

\section{Project Monitoring}

The main efforts to date were the development of a riffle-pool design in urban streams through hydraulic modeling, and construction of the design to assess whether the ecohydraulic concepts applied suggest biological integrity may be possible. Post-construction monitoring at this time does not constitute statistical analysis of potential geomorphic and biological improvements. It represents a preliminary assessment after one-year post construction with two primary objectives: 1) to identify if the project riffle structures remained stable, and 2) report on general biota metric trends from the project construction. Continued site monitoring and study development specifically designed to assess biological integrity will be future research.

\subsection{Geomorphic Surveys}

In March 2012, immediately following completion of project construction, representative cross-sections of both the riffle and pool sections were surveyed. In April 2013 these crosssections were resurveyed to identify any major adjustments in channel form occurring in 
response to hydrologic events occurring over this 14 month period. These historical crosssections were surveyed utilizing a Trimble Total Station and Recon Data Logger.

Stage data was recorded during the period between topographical surveys utilizing a Global Water ${ }^{\mathrm{TM}}$ WL400 Level Sensor. Review of the flow data indicated floodplain connection for 8 individual flow events during the elapsed period between topographical surveys, representing multiple events where channel forming shear stresses would be likely. Overall, cross-sectional form was relatively stable among all cross-sections with no apparent indications of instability or aggradation (Fig. 14).

\subsection{Biological Surveys}

Tennessee, like most U.S. states, relies on biotic indicators to determine whether a stream is impaired or not. The level of impairment is based on benthic macroinvertebrate samples (TDEC, 2011). The Tennessee Macroinvertebrate Index (TMI) utilizes semi-quantitative single habitat surveys (SQKICK or SQBANK) to determine biocriteria by ecoregion. The SQKICK method is a qualitative measure based on quantitative analysis of community structure at sampling sites, giving consideration to both tolerant and intolerant species. Biometrics expected to decrease with increased pollution include: taxa richness (TR), Ephemeroptera Plecoptera Trichoptera richness (EPT), EPT abundance excluding Cheumatopsyche (\%EPT-Cheum), and percent contribution of organisms that build fixed retreats or have adaptations to attach to surfaces in flowing waters (\% Clingers). Biometrics expected to increase with increased pollution include: percent Oligochaetes and Chironomids (\%OC), North Carolina Biotic Index (NCBI), and \% TN nutrient tolerant organisms (\%TNutol) (TDEC, 2011).

In July 2009 a TDEC SQKICK sampling effort was conducted at the rehabilitation site prior to any construction activities. In August 2012 and 2013 SQKICK sampling efforts were 
conducted after final construction by Knox County Stormwater. The comparison of these surveys shows what appears to be a general trending improvement in both intolerant and tolerant metrics and can be seen in Table 2 .

The fish Index of Biotic Integrity (IBI) is a survey designed to measure biological integrity at a stream site (Sain, 2006). Through comparison of site specific sub-indices to reference reach sub-indices a qualitative assessment was made of biological integrity based on community structure at the site. IBI sub-indices expected to decrease with increased habitat alteration include: number of native fish species, number of darter species, number of sunfish species, number of sucker species, number of intolerant species, percent specialized insectivores, and percent piscivores. IBI sub-indices expected to increase with increased pollution and/or habitat alteration include percent tolerant species, percent omnivores and stoneroller species, percent hybrids, and percent anomalies. In January of 2010 an IBI sampling effort was conducted by TDEC personnel at the rehabilitation site prior to any construction activities. In September of 2013 a second IBI sampling effort was conducted by TDEC personnel after final construction. Comparison of the two surveys indicates incremental improvement in fish community diversity (Table 3).

\section{Restoration Implications and Conclusions}

The riffle-pool design developed in this study and pilot project constructed from the design demonstrated as a case study that urban stream habitat have the potential to be rehabilitated and incrementally improve biotic integrity. Urban streams suffer ecologically from a host of multistressors including poor water quality, sedimentation, and invasive species, so returning it to a pristine condition is not possible. Considering the impact of hydromodification on channel stability, using geomorphic and hydraulic principles in the development of the morphological 
design rather than an anti-log design approach was a critical element. Continued channel monitoring will determine whether the design can be sustainable for the long-term.

This case study also presents to stream restoration practitioners the methodological design process founded in ecological engineering principles. River2D hydraulic modeling provided key information that a practitioner can use to assess channel stability, integrated with field measurements of critical shear stress on the banks, and bedload transport characteristics. The ecohydraulics design approach using the River2D model incorporated a pre-construction assessment of habitat quality, integrating fluvial geomorphology, hydraulics, and ecological data. Knowledge gained from this case study will be applied to future research investigating in detail the 3D hydraulics and geomprohic processes at these constructed riffles using an acoustic Doppler velocimeter at multiple flow stages, and examine the functional traits of new fish species that recolonize the restored reach.

\section{Acknowledgements}

Funding to construct the project came from a Tennessee Department of Agriculture 319 Grant. The various theses and modeling work were funded by multiple sources including: USGS 104B WRRI Grant through the Tennessee Water Resources Research Center; Tennessee Department of Environment and Conservation WMREI Funds; USDA National Sedimentation Laboratory, and US Department of Energy Oak Ridge National Laboratory. Stream restoration project logistics help by Tim Gangaware and Roy Arthur (TWRRC); and Greg Babbit and Patrick McMahon (EcoFlow Consultants). Design support was provided by Knox County Stormwater Engineering Department, with the help from Andrew Dodson and Michael Hamrick. Field work assistance included William Cantrell, Tara Mallsion, Brady McPherson, many other UTK students and Knox County AmeriCorps Volunteers. 


\section{References}

Aadland, L.P. 1993, Stream habitat types: their fish assemblages and relationship to flow. N Am J. Fish Mgmt. 13, 790-806.

Allan, J.D.; Castillo, M.M. 2007. Stream Ecology: Structure and Function of Running Waters. Springer Publ.

Annable, W.K.; Watson, C.C.; Thompson, P.J. 2012. Quasi-equilibrium conditions of urban gravel-bed stream channels in southern Ontario, Canada. Regulated Rivers 28, 302-325.

Bernhardt, E.S.; Palmer, M.A. 2007. Restoring streams in an urbanizing world. Freshwater Biology. 52, 738-751.

Bledsoe, B.P.; Stein, E.D.; Hawley, R.J.; Booth, D. 2012. Framework and tool for rapid assessment of stream susceptibility to hydromodification. Journal of the American Water Resources Association 48, 788-808.

Bledsoe, B.P.; Watson, C.C. 2001. Effects of urbanization on channel stability. J Am Water Resources Assoc. 37, 255-270.

Bockelmann, B.N.; Fenrich, E.K.; Lin, B.; Falconer, R.A. 2004. Development of ecohydraulics model for stream restoration and river restoration. J. Ecological Engineering 22, 227-235.

Booker, D.J.; Dunbar, M.J. 2004. Application of physical habitat simulation (PHABSIM) modelling to modified urban river channels. River Research and Applications 20:167-183.

Booth, D.B.; Jackson, C.R. 1997. Urbanization of aquatic systems - degradation thresholds, stormwater detection, and the limits of mitigation. J. Am. Water Resources Association. 33, 1077-1090.

Bovee, K.D.; Lamb, B.L.; Bartholow, .J.M.; Stalnaker, C.B.; Taylor, J.; Henroksen, J. 1998. Stream Habitat Analysis Using the Instream Flow Incremental Methodology. US Geological 
Survey, Biological Resources Division Information and Technology Report. USGS/BRD1998-0004.

Bunte, K.; Abt, S.R.; Polondy, J.P.; Ryan, S.E. 2004. Measurement of coarse gravel and cobble transport using portable bedload traps. ASCE J. Hydraulic Engineering 130(9), 879-893.

Cantrell, W. 2009. Method of Evaluation for Stream Bed Shear Stress and Sediment Transport Capacity in Urbanizing Watershed: Implications for Stream Restoration. MS Thesis, University of Tennessee, Knoxville.

Cao, Z.; Carling, P.; Oakley, R. 2003. Flow reversal over a natural pool-riffle sequence: a computational study. Earth Surface Processes and Landforms 28, 689-705.

Carling, P.A.; Wood, N. 1994. Simulation of flow over pool-riffle topography: A consideration of the velocity reversal hypothesis. Earth Surface Processes \& Landforms 19, 319-322.

Cianfrani, C.M.; Hession, W.C.; Rizzo, D.M. 2006. Watershed imperviousness impacts on channel condition in southeastern Pennsylvania. J. Am. Water Resources Association 42, 941-956.

Clark, L.A.; Wynn, T.M. 2007. Methods for determining streambank critical shear stress and soil erodibility: implications for erosion rate predictions. Trans. ASABE 50, 95-106.

Clifford, N.J. 1993. Differential bed sedimentology and the maintenance of riffle-pool sequences. Catena 20, 447-468.

Clifford, N.J.; Harmar, O.P.; Harvey, G.; Petts, G.E. 2006. Physical habitat, ecohydraulics and river design: a review and re-evaluation of some popular concepts and methods. Aquatic Conservation: Marine and Freshwater Ecosystems 16, 389-408.

Colosimo, M.F.; Wilcock, P.R. 2007. Alluvial sedimentation and erosion in an urbanizing watershed, Gwynns Falls, Maryland. J. Am. Water Resources Association 43, 499-521. 
de Almeida, G.A.M.; Rodriguez, J.F. 2011. Understanding pool-riffle dynamics through continuous morphological simulations. Water Resources Research 47, 1-15.

Dietrich, W.E. 1987. Mechanics of flow and sediment transport in river bends. In: Richards K. (ed.), River Channel Environment and Process: Basil Blackwell Publ.

Dworak, F.J. 2005. Characterizing Turbulence Structure along Woody Vegetated Banks in Incised Channels: Implications for Stream Restoration. MS Thesis, University of Tennnesse Knoxville.

Emery, J.C.; Gurnell, A.M.; Clifford, N.J.; Petts, G.E.; Morrissey, I.P.; Soar, P.J. 2003. Classifying the hydraulic performance of riffle-pool bedforms for habitat assessment and river rehabilitation design. River Research and Applications 19, 553-549.

Fitzpatrick, F.A.; Harris, M.A.; Arnold, T.L.; Richards, K.D. 2004. Urbanization influences on aquatic communities in northwestern Illinois streams. J. Am. Water Resources Association 40, 461-475.

Frothingham, K.M.; Rhoads, B.L. 2003. Three-dimensional flow structure and channel change in an asymmetric compound meander loop, Embarras River, Illinois. Earth Surface Processes and Landforms. 28, 625-644.

Ghanem, A.; Steffler, P.; Hicks, F.; Katopodis, C. 1996. Two-dimensional hydraulic simulation of physical habitat conditions in flowing streams. Regulated Rivers: Research \& Management 12, 185-200.

Gregory, K.J.; Gurnell, A.M.; Hill, C.T.; Toooth, S. 1994. Stability of the pool-riffle sequence in changing river channels. Regulated Rivers: Research and Management 9, 35-43.

Hanson, G.J. 1990. Surface erodibility of earthen channels at high stresses. Part II - Developing an in situ testing device. Trans. ASAE 33, 132-137. 
Harper, D.; Ebrahimnezhad, M.; Cot, F.C.I. 1998. Artificial riffles in river rehabilitation: setting the goals and measuring the successes. Aquatic Conserv: Mar Freshw Ecosyst. 8, 5-16.

Heritage, G.; Milan, D. 2004. A conceptual model of the role of excess energy in the maintenance of a riffle-pool sequence. Catena 58, 235-257.

Hession, C.W.; Pizzuto, J.E.; Johnson, T.E.; Horwitz, R.J. 2003. Influence of bank vegetation on channel morphology in rural and urban watersheds. Geology 31, 147-150.

Hey, R.D.; Thorne, C.R. 1986. Stable channels with mobile gravel beds. ASCE Journal of Hydraulic Engineering. 112, 671-689.

Jennings, D.B.; Jarnagin, S.T. 2002. Changes in anthropogenic impervious surfaces, precipitation and daily streamflow discharge: a historical perspective in a mid-Atlantic subwatershed. Landscape Ecology. 17, 471-489.

Johnson, P.A.; Fecko, B.J. 2008. Regional channel geometry equations: a statsitical comparison for physiographic provinces in the eastern US. River Research and Applications 24, 823-834.

Kang, R.S.; Marston, R.A. 2006. Geomorphic effects of rural-to-urban land use conversion on three streams in the Central Redbed Plains of Oklahoma. Geomorphology 79, 488-506.

Keller, E.A.; Florsheim, J.L. 1993. Velocity-reversal hypothesis: a model approach. Earth Surface Processes and Landforms 18, 733-740.

Keller, E.A.; Melhorn, W.N. 1978. Rhythmic spacing and origin of pools and riffles. Geological Society of America Bulletin 89, 723-730.

Knighton, D. 1998. Fluvial Forms and Processes: A New Perspective: Arnold Publ., London.

Lamouroux, N.; Poff, N.L.; Angermeier, P.L. 2002. Intercontinental convergence of fish community traits along geomorphic and hydraulic gradients. Ecology 83, 1792-1807. 
Lisle, T. 1979. A sorting mechanism for a riffle-pool sequence: Summary. Geological Society of America Bulletin, Part I. 90, 616-617.

Mallison, T.L. 2008. Comparing In Situ Submerged Jet Test Device and Laboratory Flume Methods to Estimate Erosional Properties of Cohesive Soils for Bank Stability Models. MS Thesis, University of Tennessee, Knoxville.

Matthews, W.J. 1990. Spatial and temporal variation in fishes of riffle habitats: A comparison of analytical approaches for the Roanoke River. Am Midl Nat. 124, 31-45.

McBride, M.; Booth, D.B. Urban impacts on physical stream condition: effects of spatial scale, connectivity, and longitudinal trends. J. Am. Water Resources Association. 41:565-580; 2005

Millar, R.G. 2004. Theoretical regime equations for mobile gravel-bed rivers with stable banks. Geomorphology 64, 207-220.

Morris, S.; Moses, T. 1999. Urban stream rehabilitation: a design and construction case study. Environmental Management 23, 165-177.

Newson, M.D.; Newson, C.L. 2000. Geomorphology, ecology and river channel habitat: mesoscale approaches to basin-scale challenges. Progress in Physical Geography 24, 195-217.

Niezgoda, S.L.; Johnson, P.A. 2005. Improving the urban stream restoration effort: identifying critical form and processes relationships. Environmental Management 35, 579-592.

Niezgoda, S.L.; Johnson, P.A. 2006. Modeling the long term impacts of using rigid structures in stream channel restoration. J. Am. Water Resources Association 42, 1597-1613.

Payne, T.R. 2008. Technical Memorandum to Appalachian Power Company; Instream Flow Needs Workgroup - Claytor Project 739-018. Thomas R. Payne \& Associates, Arcata, CA. Paul, M.J.; Meyer, J.L. 2001. Streams in the urban landscape. Annual Review of Ecology and Systematics 32, 333-365. 
Poff, N.L. 1997. Landscape filters and species traits: Towards mechanistic understanding and prediction in stream ecology. J. North American Benthological Society 16, 391-409.

Poff, N.L.; Olden, J.D.; Vieira, N.K.M.; Finn, D.S.; Simmons, M.P.; Kondratieff, B.C. 2006. Functional trait niches of North American lotic insects: traits-based ecological applications in light of phylogenetic relationships. J. North American Benthological Society 25, 730-755.

Rabeni, C.F.; Sowa, S.P. 1996. Integrating biological realism into habitat restoration and conservation strategies for small streams. Can J Fish Aquat Sci. 53, 252-259.

Rhoads, B.L.; Schwartz, J.S.; Porter, S. 2003. Stream geomorphology, bank vegetation, and three-dimensional habitat hydraulics for fish in midwestern agricultural streams. Water Resources Research 39, 1218-1230.

Rhoads, B.L.; Welford, M.R. 1991. Initiation of river meandering. Progress in Physical Geography 15, 127-156.

Richards, K.S. 1976. The morphology of riffle-pool sequences. Earth Surface Lanforms and Processes 1, 71-88.

Rodriguez J.F.; Garcia, M.H. 2008. Laboratory measurements of 3-D flow patterns and turbulence in straight open channel with rough bed. J. Hydraulic Research 46, 454-465.

Rosgen, D.L. 1996. Applied River Morphology. Wildlands Hydrology, Colorado.

Rosgen, D.L. 2008. DISCUSSION: "Critical evaluation of how the Rosgen classification and associated 'natural channel design' methods fail to integrate and quantify fluvial processes and channel response". J. Am. Water Resources Association. 44:782-792.

Sain, R.L. 2006. Characterizing How Fish Communities and Physical Habitat Structure are Affected by Urbanization in an East Tennessee Watershed. MS Thesis, University of Tennessee, Knoxville. 
Schwartz, J.S. 2002. Stream Habitat Characterized by Stage-specific Flows and Threedimensional Geomorphological Complexity: Development of Ecological Criteria for Stream Restoration Design. PhD Dissertation, University of Illinois, Urbana-Champaign.

Schwartz, J.S. 2003. Use of a two-dimensional hydrodynamic model for restoration design of high-flow habitat in low-gradient Midwest streams. Pages 242-251 In M. Clar, D. Carpenter, J. Garcie, and L. Slate (editors). Proceedings of the Symposium on the Protection and Restoration of Urban and Rural Streams, June 23-25, 2003, Philadelphia, PA; American Society of Civil Engineers, Reston, VA.

Schwartz, J.S.; Herricks, E.E. 2004. Use of prepositioned areal electrofishing devices with rod electrodes in small streams. North American Journal of Fisheries Management 24, 13301340.

Schwartz, J.S.; Herricks, E.E. 2005. Fish use of stage-specific fluvial habitats as refuge patches during a flood in a low-gradient Illinois stream. Can J Fish Aquat Sci. 62, 1540-1552.

Schwartz, J.S.; Herricks, E.E. 2007. Evaluation of pool-riffle naturalization structures on habitat complexity and the fish community in an urban Illinois stream. River Research and Applications 23, 451-466.

Schwartz, J.S.; Herricks, E.E. 2008. Fish use of ecohydraulic-based mesohabitat units in a lowgradient Illinois stream: implications for stream restoration. Aquatic Conservation: Marine and Freshwater Ecosystems.18, 852-866.

Schwartz, J.S.; Herricks, E.E., Rhoads, B.L. 2001. Integrating geomorphology, hydraulics, and ecological criteria to support stream naturalization in East-Central Illinois. ASCE/EWRI World Water and Environmental Resources Congress; Orlando, Florida; May 2001. 
Schwartz, J.S.; Neff, K.J. 2011. Use of River2D hydrodynamic model for stream restoration assessment and design. Proceedings of the World Water \& Environmental Resources Congress; Pages 2593-2602. ASCE Environmental and Water Resources Institute, Palm Springs CA; May 22-26, 2011. DOI. 10.1061/41173(414)269.

Schwartz, J.S.; Simon, A.; Klimetz, L. 2011. Use of fish functional traits to associate in-stream suspended sediment transport metrics with biological impairment. Environmental Monitoring and Assessment 179, 347-369.

Sear, D.A. 1996. Sediment transport processes in pool-riffle sequences. Earth Surface Processes and Landforms 21, 241-262.

Sear, D.A.; Newson, M.D. 2004. The hydraulic impact and performance of a lowland rehabilitation scheme based on pool-riffle installation: The River Waveney, Scole, Suffolk, UK. River Research and Applications 20, 847-863.

Shamloo, H.; Rajaratnam, R.; Katopodis, C. 2002. Hydraulics of simple habitat structures. Journal of Hydraulic Research 39, 351-366.

Shields, F.D., Copeland, R.R.; Klingeman, P.C.; Doyle, M.W. Simon, A. 2003. Design for stream restoration. ASCE Journal of Hydraulic Engineering 129, 575-584.

Simon, A. 1995. Adjustment and recovery of unstable alluvial channels: Identification and approaches for engineering management. Earth Surfaces Process and Landforms 20, 611628.

Simon, A.; Doyle, M.; Kondolf, M.; Shields, F.D.; Rhoads, B.; McPhillips, M. 2007. Critical evaluation of how the Rosgen classification and associated "natural channel design" methods fail to integrate and quantify fluvial processes and channel response. J. Am. Water Resources Association 43, 1117-1131. 
Simon, A.; Hupp, C.R. 1990. The recovery of alluvial systems in response to imposed channel modifications, West Tennessee, USA. Vegetation and Erosion. J.B. Thornes (ed). London, John Wiley \& Sons Ltd.: 145-160.

Simon, A.; Rinaldi, M. 2006. Disturbance, stream incision, and channel evolution: the roles of excess transport capacity and boundary materials in controlling channel response. Geomorphology 79, 361-383.

Slate, L.O.; Shields, F.D.; Schwartz, J.S.; Carpenter, D.D.; Freeman, G. 2007. Engineering design standards and liability for stream channel restoration. ASCE J Hydraulic Engineering 133, 1099-1102.

Smith, S.M.; Prestegaard, K.L. 2005. Hydraulic performance of a morphology-based stream channel design. Water Resources Research 41, doi:10.1029/2004WR003926.

Steffler, P.; Blackburn, J. 2002. Two-dimensional Depth Averaged Model of River Hydrodynamics and Fish Habitat, River2D User's Manual, University of Alberta, Canada.

Sturm, T.W. 2010. Open Channel Hydraulics: McGraw-Hill Publ.

Thompson, A. 1986. Secondary flows and the pool-riffle unit: a case study of the processes of meander development. Earth Surfures and Process Landforms 11, 631-641.

Vannote, R.L.; Minshall, G.W.; Cummins, K.W.; Sedell, J.R.; Cushing, C.E. 1980. The river continuum concept. Can J Fish Aquat Sci. 37, 130-137.

Walsh, C.J.; Fletcher, T.D.; Ladson, A.R. 2005a. Stream restoration in urban catchments through redesigning stormwater systems: looking to the catchment to save the stream. J. North American Benthological Society 24, 690-705. 
Walsh, C.J.; Roy, A.H.; Feminella, J.W.; Cottingham, P.D.; Groffman, P.M.; Morgan II, R.P. 2005b. The urban stream syndrome: current knowledge and the search for a cure. J. North American Benthological Society 24, 706-723.

Wang, L.; Lyons, J.; Kanehl, P. 2001. Impacts of urbanization on stream habitat and fish across multiple spatial scales. Environmental Management 28, 255-266.

Williams, K.H. 2005. Linking channel stability and bed sediment characteristics to biological integrity in Tennessee Ridge and Valley streams. MS Thesis. University of Tennessee Knoxville.

Wilkinson, S.N.; Keller, R.J.; Rutherfund, I.D. 2004. Phase-shifts in shear stress as an explanation for the maintenance of pool-riffle sequences. Earth Surface Processes and Landforms 29, 737-753.

Yalin, M.S.1992. River Mechanics: Pergamon Press Oxford Publ.

Yang, C.T. Formation of riffles and pools. Water Resources Research 7, 1567-1574.

Zale, A.D.; Parish, D.L.; Sutton, T.M. 2013. Fisheries Techniques, $3^{\text {rd }}$ Edition. American Fisheries Society, Bethesda, Maryland. 


\section{Restoring riffle-pool structure in an incised, straightened urban stream channel using an ecohydraulic modeling approach}

John S. Schwartz ${ }^{*}{ }^{1}$, Keil J. Neff ${ }^{2}$, Frank E. Dworak ${ }^{3}$, and Robert R. Woockman ${ }^{4}$

* Corresponding Author

${ }^{1}$ Associate Professor; University of Tennessee, Department of Civil and Environmental Engineering; 413 John D. Tickle Engineering Building, Knoxville, Tennessee 37996; Phone (865) 974-7721; Email: jschwart@utk.edu

${ }^{2}$ Senior Project Engineer; Geosyntec Consultants, 2240 Sutherland Avenue, Knoxville, Tennessee 37919; Phone (865) 330-0037; Email: kjn.water@ gmail.com

${ }^{3}$ Hydraulic Engineer; US Bureau of Reclamation, 6th \& Kipling, Building 67, Denver, Colorado 80225; Phone: 303-445-2547; Email: fdworak@usbr.gov

${ }^{4}$ PhD Graduate Research Assistant; University of Tennessee, Department of Civil and Environmental Engineering; 411 John D. Tickle Engineering Building, Knoxville, Tennessee 37996; Email: rwoockman@yahoo.com

Revised April 13, 2014 


\section{ABSTRACT}

Streams in urban and urbanizing watersheds are impacted by altered runoff hydrology and sediment yields, floodplain modifications, and channel relocations. One morphological response to urbanization is degradation of pool-riffle sequences. Pools and riffles are fundamental mesohabitat units where many lotic biota have evolved to occupy preferentially, and support diverse biological communities. Restoring self-maintaining pool-riffle structures is essential to the ecological rehabilitation of urban streams when lost. However restoring these structures can be problematic in straightened urban streams constrained by civil infrastructure preventing channel re-meandering. The project goal was to utilize geomorphic, hydraulic, and ecological principles to rehabilitate a study reach in a confined geomorphic setting with a primary emphasis developing a stable riffle design that improves habitat patch dynamics. A 270-m tree-lined study site was selected on Beaver Creek, Knox County, East Tennessee. Through experimental 3D and 2D hydraulic modeling, a riffle design was developed consisting of removing trees at expanded channel locations, placing $3.8-\mathrm{cm}$ gravel substrate for the riffle bed, and deepening the pool prior to riffle entrance. Riffle-pool maintenance processes of the proposed design included occurrence of shear stress reversal between low- and high-flows, and high-flow accelerationdeceleration from pools to riffles. Cobble was places on riffles for leaf pack formation, and root wads on location of bank erosion vulnerability. River2D provided useful design information for stream restoration practitioners to assess pre-construction channel stability and habitat quality. In this case study, an ecohydraulic modeling approach to urban stream restoration is described. Construction of four pool-riffle structures was completed in March 2012, and a geomorphic survey completed in April 2013 observed the riffle structures remained stable even with the project site experiencing eight bankfull events. Post-construction monitoring has shown that the 
unique design for planform-constrained urban channels has promise for increasing hydraulic habitat diversity and improving biotic integrity in these stressed environments.

\section{Keywords}

urban streams, stream restoration, ecohydraulic design, River2D model, riffle-pool habitat, channel incision 


\section{Introduction}

Streams in urban and urbanizing watersheds are impacted by hydromodification and channelization which degrade macro-bedform structure providing essential habitat for aquatic biota (Booth and Jackson, 1997; Wang et al., 2001; Fitzpatrick et al., 2004; Walsh et al., 2005a; Bernhardt and Palmer, 2007). Hydromodification from increased impervious surfaces results in higher peak flows, greater runoff volumes, and decreased summer baseflows compared with streams in unaltered watersheds (Paul and Meyer, 2001; Jennings and Jarnagin, 2002; Annable et al., 2012). Channelization includes relocation and straightening to accommodate urban land development, and where agriculture practices prior to urbanization used it to increase valleybottom utilization and improve drainage (Morris and Moses, 1999; Wohl, 2005; O’Driscoll et al., 2010). In urbanizing watersheds, streams can become laterally constrained by adjacent floodplain development, modifying natural geomorphological processes (Wade et al., 2002; McBride and Booth, 2005; Kang and Marston, 2006). Documented modifications to natural processes include channel incision, a deepening and widening of the form morphology, and a loss of riffle-pool sequences (Simon and Hupp, 1990; Gregory et al., 1994; Simon, 1995; Bledsoe and Watson, 2001; Cianfrani and Hession, 2006; Colosimo and Wilcock, 2007). As a consequence, the loss of riffle-pool sequences severely degrades stream habitat quality and ecological function. Thus restoring stable riffle-pool structures must be a primary stream restoration objective (Emery et al., 2003; Sear and Newson, 2004; Schwartz and Herricks, 2007).

The ecological importance of riffle-pool structures is widely recognized across multiple US ecoregions because biotic communities, particularly fish and benthic macroinvertebrates have evolved to selectively occupy pools and riffles (Lamouroux et al., 2002; Poff et al., 2006; Schwartz et al., 2011; Keck et al., 2014). Based on individual species functional traits and life 
histories, pool or riffle habitat use are partitioned spatially extracting different tropic resources and expressing varying ecological functions, i.e., feeding, reproduction, predation and hydraulic refugia (Mathews 1990; Aadland. 1993; Newson and Newson, 2000; Schwartz and Herricks, 2005, 2008). Stream restoration efforts enhancing habitat structure need to consider the ecological functions associated with species life histories for a diverse biological community (Rabeni and Sowa, 1996; Schwartz, 2002; Clifford et al., 2006). Achieving self-maintaining riffle-pool sequences as habitat structure is problematic when geomorphological processes are impacted by urban hydromodification (Harper et al., 1998; Walsh et al., 2005b).

Self-maintaining riffle-pool morphology in natural alluvial channels occurs when adequate bedload sediment supply is transported and deposited by local hydraulics such that this morphology operates in dynamic equilibrium with channel forming flows (Hey and Thorne, 1986; Clifford, 1993; Sear, 1996; Knighton, 1998; deAlmeida and Rodriguez, 2011). These flows are generally recognized with a 1.5- to 2-year return frequency, and riffle cross-sectional areas are wider and shallower than pools, and riffle spacing longitudinally averages 5 to 7 channel unit widths (Richards, 1976; Keller and Melborn, 1978; Gregory et al., 1994; Millar, 2004; Johnson and Frecko, 2008). Several geomorphological processes have been suggested as key principles for the development and maintenance of riffle-pool structures. These processes include the velocity or shear stress reversal hypothesis, reach-scale helical flow patterns, and turbulence scaling (Rhoads and Welford, 1991; Yalin, 1992; Cao et al., 2004).

The velocity or shear stress reversal hypothesis describes riffles with greater velocity and bed shear stress than pools during low-stage flows, opposite of which during high flows where greater velocity and shear scour pools compared to riffles where bedload deposits (Lisle, 1979; Keller and Florsheim, 1993, Carling, 1992; Cao et al., 2004; Wilkinson et al., 2004). This 
hypothesis characterizes a geomorphic process for a self-maintaining morphology, however hydraulic resistance from bed and banks and its influence on reach-scale hydraulics and scaling turbulence patterns also appear to be a dominant process (Nelson et al. 1995; Lawless and Robert, 2001; Ma et al., 2002; Rodriguez and Garcia, 2008). Reach-scale helical flow patterns form from boundary flow resistance, creating geomorphic processes for pool-riffle (bar unit) self-maintenance in both straight and meandering channels without excessive in-stream structural elements (Dietrich, 1987; Rhoads and Welford, 1991; Tamburrino and Gullier, 1999;

Frothingham and Rhoads, 2003). Yalin (1992) describes turbulent eddy development and a "bursting" cycle associated with boundary resistance in which turbulent flow structures scale to channel depth leading to riffle-pool sequence development and self-maintenance. Others have described the role of near-bed turbulence structure on macro-bedform maintenance in gravel-bed rivers (Papanicolaou et al., 2001; Roy et al., 2004; Lamarre and Roy, 2005). Less known is how bank vegetation affects reach-scale hydraulic patterns and turbulence scaling, affecting rifflepool maintenance processes. Although it is well-document that bank vegetation influences stream hydraulics and overall channel stability (Rhoads et al., 2003; Hession et al., 2003; Simon and Rinaldi, 2006; Clark and Wynn, 2007). Relationships between bed and bank structures and their influence on reach-scale turbulence patterns need to be considered for restoration designs.

A fundamental question remains whether these hydraulic and geomorphic processes can be applied in urban streams such that a stable 'natural' channel can sustain a riffle-pool sequence form over time while confining lateral adjustment. In general, stream restoration practice today have not applied multi-dimensional free-surface hydraulics, mostly relying on an anti-log reference reach approach (Rosgen, 2006; Neizgoda and Johnson, 2005). Conflicting assessments of the reference reach approach for stream restoration has been discussed (Shields et al., 2003; 
Bernhardt and Palmer, 2007; Nagle, 2007; Slate et al., 2007; Simon et al., 2007; Rosgen, 2008). In urban streams impacted by watershed hydromodification, this approach can be problematic due to the fact reference reaches may not appropriately represent non-equilibrium streams (Bledsoe and Watson, 2001; Doyle et al., 2007).

A common restoration practice in non-equilibrium streams with incising channels is to use hydraulic grade controls consisting of various weir structures (Rosgen, 1996; Niezgoda and Johnson, 2006; Bledsoe et al., 2012). However in low-gradient streams, weir structures can create long pools and potentially because of their height creates an upstream backwater inundating riffles during low flow. Many design problems for stream restoration in nonequilibrium conditions can be aided by the use of hydrologic and hydraulic models that quantify changing flow regimes associated with urbanization. Models are also valuable tools to test design ideas for stable riffle-pool structures and apply ecohydraulic concepts (Shamloo et. al., 2002; Bockelmann et al., 2003; Booker et al., 2003; Booker and Dunbar, 2004; Smith and Prestegarrd, 2005). Noting that the return to a pristine is not possible in urban streams, an ecological engineering approach is necessary to improve biological integrity (Van Bohemen, 1998; Schwartz et al., 2001).

As a case study, the goal of this paper is to describe an ecohydraulic design process in order to restore self-maintaining riffle-pool structures in a straightened, incised urban stream where channel planform is laterally constrained by infrastructure. The specific objectives of this study were to: 1) assess geomorphic concepts for self-maintaining riffle-pool sequences utilizing multidimensional hydraulic models; 2) utilize ecological data and integrate that data into a hydraulic modeling design process; and 3) from a newly proposed riffle-pool design, construct field-scale structures and assess stability and biological integrity. 


\section{Background Information}

\subsection{Study Site}

The study site included a 270-m reach of Beaver Creek located in Knox County, Tennessee (Fig. 1). The watershed lies in the Ridge and Valley physiological providences, consisting of a trellis drainage pattern. The drainage area is $39 \mathrm{~km}^{2}$ containing $14.2 \%$ urban developed lands (residential, commercial, and industrial) based on the USGS 2006 National Land Cover Database. In general, the upper Beaver Creek watershed has been urbanized concurrently with the overall metropolitan growth of Knoxville. Historically, the stream was channelized when the adjacent land was used for dairy production with local residents indicating channelization occurred in the 1930s, but no direct evidence was obtained on an exact date.

The channel has incised over the past decade likely due to hydromodification as evidenced by the tree trunk curvature (Fig. 2). The 6.5-m wide channelized reach has an average slope of $0.0001 \mathrm{~m} / \mathrm{m}$, and both bank and bed consist of cohesive soils. Trees line the channel on both banks and impede flows greater than $1.7 \mathrm{~m}^{3} / \mathrm{s}$. Bankfull flow was approximately $4.0 \mathrm{~m}^{3} / \mathrm{s}$, and defined as the stage overtopping the bank onto the floodplain. A GlobalWater WL400 stage recorder was installed in August 2009, and has continuously recorded flow stage at 15-min intervals. Mass bank-failures have not occurred likely due to the cohesive soil property and the dense woody vegetation on the banks. The study reach was observed with diminished riffle-pool morphology, with the habitat structure consisting mostly of long glides and local scour pools adjacent to large bank root masses (Dworak, 2005).

The straight channel is bordered on the west with a Food City grocery store and parking lot, and on the east bank with a paved greenway (Fig. 1). The Knox County Parks and Recreation Department manages the greenway. At the end of the study reach protecting a pedestrian bridge 
to the greenway is a rip-rap rock grade control spanning the channel. Both sides of the Beaver Creek were constrained with urban development, including buried optical communication lines preventing a natural channel design approach per Hey (2006) utilizing re-meandering.

\subsection{Pre-Construction Geomorphic and Biological Site Data}

Sediment particles sizes for bed material and transported bedload, and bank critical shear stress $\left(\tau_{\mathrm{c}}\right)$ were geomorphic data obtained to support the restoration design process. Beaver Creek was incised into cohesive material, with the bed covered with thin-veneer patches of sand and fine gravel mixtures. The $\mathrm{D}_{50}$ of the bed sediment per standard pebble count was measured as 6 mm (Cantrell, 2009). Cantrell (2009) also measured bedload transport with Bunte et al. (2004) net traps, in which the transported material was measured as $1.4-\mathrm{mm}_{50}$ and $18 \mathrm{D}_{\max }$, and the reach was generally determined to be supply-limited. Because urbanization has the potential to reduce bedload sources through stormwater drainage piping and detention facilities (MacRae, 1997), understanding whether a reach is supply- or capacity-limited was important.

Thus the measurements by Cantrell (2009) indicated that the design must specify placement of riffle gravel substrate. The $\tau_{\mathrm{c}}$ for the cohesive bank material was also needed in the design process to identify potential locations where excessive erosion could compromise channel stability. The bank $\tau_{\mathrm{c}}$ was determined as 3.8 Pa utilizing a Hanson et al. (1990) jet test device (Mallison, 2008). This $\tau_{\mathrm{c}}$ was compared with bed shear stress $\left(\tau_{0}\right)$ estimates from River2D model simulations at bankfull discharge $\left(4 \mathrm{~m}^{3} / \mathrm{s}\right)$ to identify susceptible locations that may require local bank scour protection.

Biological data included pre-construction surveys for benthic macroinvertebrates and fish. Benthic macroinvertebrate data identified the Beaver Creek site as water quality impaired from "siltation" and habitat alternation, and the site was reported on the state 303(d) list (TDEC, 
2006). Williams (2005) states a Tennessee Macroinvertebrate Index (TMI) score of 28 (TMI range 0-42), which is considered partially impaired by state water quality statues. Within the Beaver Creek watershed, fish Indices of Biotic Integrity (IBI) ranged from 27 to 50 (IBI range 060), and were inversely correlated with percent urban land cover (Sain, 2006). Sain (2006) found healthy fish communities within the watershed as potential fish source areas in order to recolonize degraded reaches, including many intolerant Centrarchidae, Cyprinidae, and Percidae species. The fish surveys indicated that restored riffle-pool habitat would likely benefit fish communities at the Beaver Creek study reach.

\section{Development of a Riffle-Pool Design for Urban Stream Restoration}

As noted above, development of a riffle-pool design for a low-gradient, straight urban stream constrained by urban development required the use of hydraulic models. Three- and twodimensional (3D, 2D) hydraulic models were used to investigate the influence of bank vegetation on reach-scale helical flow patterns, flow deceleration-acceleration zones longitudinally through proposed riffle-pool sequences, and shear-stress reversal for riffles and pools between low- and high-flow stages. Design development also included the application of fluid mass continuity where a 2D model illustrated the effect of increased channel cross-sectional area at proposed riffle locations on decreasing average velocities. Understanding flow resistance and turbulence patterns from tree-lined banks, and the potential role it plays in riffle-pool maintenance was particularly important in developing an urban stream restoration design strategy for forested ecoregions (Fig. 2).

The proposed conceptual design to be qualitatively assessed by hydraulic models consisted of removing trees at laterally-expanded channel areas to form a deceleration zone during high flows, and maintaining the existing narrow tree-lined channel to promote acceleration (Fig. 3). 
Within the context of the proposed design, several geomorphic questions were posed and investigated through modeling; they were: 1) does tree bank vegetation and the scaling of turbulence structure to bank trees prevent development of reach-scale helical flow patterns; 2) can acceleration-deceleration zones be created with alternating high- and low-resistant sections of stream bank, relative to each other as tree-lined and not; 3) can deceleration zones be accomplished at constructed riffles by channel expansions based on continuity principles; 4) how important is the entrance slope into a riffle structure for energy dispersion and prevention of riffle thawleg scour; and 5) is velocity/shear stress reversal observed from low- to high flow?

In addition to assessing hydraulic patterns through the proposed riffle-pool structure from 2D- and 3D-models and consistency with published geomorphic theories on maintenance processes, this case study illustrated the utility of hydraulic models in restoration by an ecohydraulic design approach. Ecological criteria were incorporated into the hydraulic modeling effort based on Physical Habitat Simulation (PHABSIM) methodology (Ghanem et al., 1996; Schwartz, 2003; Booker and Dunbar, 2004; Ernst et al., 2010). An ecohydraulic approach to restoration design integrates fluvial geomorphology, hydraulics, and ecological principles.

\subsection{Geomorphic Concepts and Hydraulic Model Design Simulations}

\subsubsection{Influence of Bank Trees on Reach-scale Hydraulic Patterns}

Background. Many theories and geomorphic process mechanisms support why riffle-pool sequences are maintained in alluvial streams (Knighton, 1998). Sequences commonly occur between 5 to 7 channel unit widths in succession in both straight and sinuous channels, and are strongly influenced by cross-sectional width to depth ratios (Keller and Melhorn, 1978, Dietrich, 1987; Gregory et al., 1994). Development and maintenance processes involve the hydrodynamics of sediment transport in the channel, and scaling of turbulence structure to form 
the oscillating patterns of bed deposition and scour (Yalin, 1992; Clifford, 1993). In straight channels, Yalin (1992) theoretically explained development of riffle-pool sequences as based on macroturbulent flow scaling and an eddy bursting process initiated by differential high- and lowspeed flow layers. Turbulent eddy development and final bursting scales to water depth, where it creates "sweep" velocity vectors orientated towards the bed inducing scour and sets up a feedback loop of continued scour sequencing at approximating six flow depths.

No one theory explains the riffle-pool formation, but observations and modeling has illustrated the importance of acceleration-deceleration patterns, and longitudinal flow alternating convergent-divergent patterns (Thompson, 1986; Rhoads and Welford, 1991). Convergentdivergent flow, combined with secondary circulation currents form helical patterns where surface flow convergence occurs at pools increasing bed shear and inducing scour during high flows, and at riffles flow convergence occurs at the stream bed reducing shear and favoring sediment deposition (Lane et al., 1998). Because the downstream velocity is greatest compared to the secondary circulation, a helical flow pattern is theoretically maintained (Frothingham and Rhoads, 2003). However most modeling and field measurements have been conducted on channels without excessive bank resistance, as which occurs in forested Appalachian streams. In general it is agreed that once formed, riffle-pool morphology controls hydraulic scour and deposition patterns through sediment transport and sorting, thereby playing a key role in equilibrium dynamics of channels (Heritage and Milan, 2004; Rodríguez and Garica, 2008).

Method. Computational fluid dynamics (CDF) model simulations were performed in order to characterize flow structures during bankfull stage examining the influence of tree-lined banks on flow resistance and reach-scale hydraulic patterns (Dworak, 2005). FLOW-3D ${ }^{\circledR}$, a threedimensional CFD model with a graphical user interface was used to generate study reach 
simulations. Study site topography was surveyed with a Trimble ${ }^{\circledR}$ total station and Recon ${ }^{\circledR}$ data-logger, extending $105 \mathrm{~m}$ as shown on Figure 1, and topography and tree locations were imported as ASCII formatted $x-y-z$ files into FLOW-3D® (Fig. 4). Trees along banks were generated as model subcomponents and represented as symmetric vertical cylinders; measured diameters were applied for 102 trees surveyed on both banks. A 3D finite element grid was generated for the entire flow field with grid spacing capable to resolve vortices around trees. A $1.68 \mathrm{~m}^{3} / \mathrm{s}$ discharge and corresponding stage of $1.72 \mathrm{~m}$ was simulated in which trees on both banks impeded flow. The turbulence closure scheme for Reynolds stresses utilized the k- $\varepsilon$ model. The roughness height coefficient "k" was computed by a FLOW3D ${ }^{\circledR}$ algorithm based on hydraulic radius and a selected Manning $n$ of 0.019. Steady-state conditions were modeled, in which computational stability was achieved over the simulation time. Full details of the FLOW3D ${ }^{\circledR}$ model set-up, boundary conditions, and model performance parameters can be found in Dworak (2005).

FLOW3D ${ }^{\circledR}$ modeling scenarios included: 1) incised channel with bank trees generating large-scale roughness, the existing condition of the study site; and 2) incised channel, where bank tree clusters were spaced 5-7 channel unit widths to create acceleration-deceleration flow patterns, a model modified condition. Dworak (2005) also modeled a scenario in the incised channel without bank trees, where bank roughness was a function of boundary morphology only, in which helical flow development was suggested by visual inspection of simulation output.

Results. FLOW3D $®$ model results presented here within include cross-sectional velocities along a longitudinal sequence for the two scenarios defined above. The datum for the longitudinal distances along the 105-m modeled reach starts with zero at the downstream boundary. Velocity vectors near bank trees were pronounced representing flow deflection, and 
forming vortices immediately downstream of trees (Fig. 5). In most cross-sections, the downstream velocity vectors dominate in the mid-channel with near-bank vectors scaling to tree or boundary roughness. Cross-sections at longitudinal distances $59.90 \mathrm{~m}$ and $55.03 \mathrm{~m}$ showed development of channel-scale secondary flow vectors, and again at distance $49.62 \mathrm{~m}$. A noticeable immediate depression in the streambed at longitudinal distance $45.84 \mathrm{~m}$ of the channel caused downward directed vectors. Large-scale heterogeneity in bed-topography, such as channel morphology and ledges within the streambed, and the presence of trees on the banks appeared to prevent the development of helical flow patterns along the modeled channel length. Scaling of turbulence structures near the trees is evident in additional modeling output in Dworak (2005), where the dissipation rate per unit mass of turbulent kinetic energy (TKE) exceeded 0.01 $\mathrm{J} / \mathrm{kg}$-s downstream of trees impeding flow. It is noted that the model was not field verified; although field measurements by a Sontek ${ }^{\mathrm{TM}}$ acoustic Doppler velocity (ADV) meter were obtained in 2007 and velocities compared well with model simulations of the unaltered channel (unpublished data). In general, the CFD results illustrate the potential for flow resistance and reach-scale turbulence structures to be heavily influenced by the densely-spaced bank trees, and potentially affecting riffle-pool maintenance hydraulics.

In order to examine the influence of sequencing bank roughness on creating accelerationdeceleration zones, a FLOW3D $®$ modeling scenario removed the tree (cylinders) on both banks from longitudinal distances approximately $30 \mathrm{~m}$ to $58 \mathrm{~m}$ and $75 \mathrm{~m}$ to $96 \mathrm{~m}$ (Dworak, 2005). Cross-sectional velocities from model were plotted along a longitudinal sequence for the same distances as with all trees modeled. Per visual inspection, development of reach-scale secondary flows appeared to occur and potentially in a helical pattern (Fig. 6). At longitudinal distance $79.85 \mathrm{~m}$, secondary flow vectors appeared orientated "left", followed by two circulation cells 
with converging vectors at the water surface at distance $77.09 \mathrm{~m}$, and a reversal of secondary flow to the "right" at $60.17 \mathrm{~m}$. The same downward directed velocities as observed in Figure 5 due to a bed slope drop is observed in Figure 6 under this modeling scenario. Results suggest that modifying tree bank resistance to promote acceleration-deceleration zones could potentially be useful strategy for stream restoration. Further research is needed to investigate this hydraulic phenomenon; however, for the purpose of developing a riffle design for straight urban streams these CFD results will be applied in this study.

\subsubsection{Influence of Channel Width Expansions and Riffle Incline Slope on Hydraulic Patterns}

Background. In order to examine the influence of channel width expansions and riffle incline slope on reach-scale hydraulics as potential design elements, River2D was used. River2D utilizes two-dimensional (2D), shallow-water, depth-averaged Saint Venant equations conserving mass and momentum through an unstructured finite element mesh (Steffler and Blackburn, 2002). As a high-resolution scheme, the River2D model allows freely intermixed subcritical and supercritical flow without the imposition of artificial eddy viscosity. For computational stability, finite element solutions are based on the Streamline Upwind Petrov-Galerkin weighted residual formation (Ghanem et al., 1996). River2D has wetting-drying capability on banks utilizing groundwater flow equations and transmissivity. Model output from River2D includes plots per finite element cell for velocity, water depth, water surface elevation, Froude number, and shear velocity (Schwartz and Neff, 2011).

Assessing the influence of gradual channel expansions on flow deceleration by mass continuity principles, River2D modeled expanded channel widths at four proposed riffle locations (Fig. 3). Fluid mass continuity was assumed for steady flow with a constant discharge is a function of cross-sectional average velocity (V) times area (A), thus by increasing $\mathrm{A}, \mathrm{V}$ must 
decrease (Sturm, 2010). As a general design approach, pre-restoration channel morphology in the model can be modified by expanding the channel width until sufficient deceleration achieves a stable riffle. In this case study, the project site was planform-constrained so the question became what were the reduced riffle velocities for the maximum allowable channel width that did not interfere with existing civil infrastructure. In addition to creating accelerationdeceleration patterns at riffle-pool sequences, River2D simulations were used to observe whether velocity and shear stress reversal occurred from low-flow to high-flow stages, fundamental to sequence maintenance. As noted earlier, the velocity/shear stress reversal hypothesis describes riffles at low-flow stages with higher velocities and shear stress relative to the pool, and during high-flow stages higher velocities and shear stress scour pools, compared with riffles where sediment tends to deposit (Keller and Florsheim, 1993, Cao et al., 2002). This sediment sorting process maintains this bedform. Dietrich (1987) elucidates this description of sediment sorting processes through a bar unit, consisting of a bar-riffle-pool structure in meanders.

Yang (1971) hypothesized that riffle-pool formation is a function of streams tending towards a minimum energy dissipation rate, thus relating to energy loss through this macro-bedform and particularly to the riffle entrance incline slope. It is suggested that the riffle entrance incline slope creates converging flow paths in the vertical enhancing turbulence and increasing energy dissipation rates. Qualitatively, a stable riffle design should include energy dissipation concepts, reducing local high-velocity flow paths, such as a riffle thawleg "jet". River2D was used to examine velocity dissipation into the modeled riffle design by varying depth of the preceding upstream pool, thus the entrance slope into the riffle.

Method. Comparisons among River2D model scenarios were used to address questions related to development of a stable riffle design for straight, incised urban channels. With 
River2D, the entire 270-m project reach was used in model simulations based on the site topography survey (Fig. 1). River2D finite element mesh development and hydraulic modeling procedures were followed as described in Steffler and Blackburn (2002). A $4.0 \mathrm{~m}^{3} / \mathrm{s}$ discharge was used for bankfull conditions, and $0.5 \mathrm{~m}^{3} / \mathrm{s}$ was used for low-flow conditions.

Modeling efforts included: 1) water depth and velocity comparison of the original channel morphology to the designed channel with expanded widths at riffles, without entrance slope modifications; 2) water depth and velocity comparison of expanded channel widths at riffles without entrance slope modifications to same lateral morphology but added approximately $0.3 \mathrm{~m}$ depth to the existing pre-riffle pool increasing riffle entrance incline slopes; and 3) shear velocity comparison between low- and high-flows for the designed channel with expanded width areas and entrance pools in order to assess the occurrence of shear stress reversals.

Results. The original topography was modeled for high- and low-flows in order to illustrate the lack of flow acceleration-deceleration zones and riffle-pool sequences (Fig. 7). These River2D simulations showed a high-velocity core mid-channel, with lower velocity very near the banks. River2D could not fully capture the effect of the tree-lined bank, but was addressed in the model by an increased roughness height $\left(\mathrm{k}_{\mathrm{s}}\right)$ of $0.1 \mathrm{~m}$ compared to a $0.02 \mathrm{~m} \mathrm{k}_{\mathrm{s}}$ for the channel bed. Water depth at low-flow stage remained relatively constant along the thawleg between 0.4 and $0.6 \mathrm{~m}$, lacking riffle-pool features. One deep pool occurred near the upstream end of the modeled reach that was approximately $0.85 \mathrm{~m}$ in depth.

The initial modeling simulations did not modify the bed topography at the entrance of the proposed riffles (Fig. 8a). Model results showed deceleration overall from the upstream and downstream narrower channels; however high-velocity jets extended into riffle thawlegs. This result indicated by expanding the channel width alone it did not decelerate velocity from riffle 
entrance completely over the mid-riffle cross-section. By having a high-velocity jet enter the riffle at mid-channel thawleg, it was believed that this could lead to an unstable riffle bed.

Next, River2D modeling simulations consisted of deepening the bed topography at the riffle entrance with the idea that this would cause converging flow paths, increasing turbulence and energy dissipation. The change in bed elevation pre-riffle to riffle for initial design with no bed modification was between 0.1 to $0.2 \mathrm{~m}$ (Fig. 8a), whereas for the final design with bed modification the change in bed elevation was approximately $0.45 \mathrm{~m}$ (Fig. 8b). The slight deepening of the bed pre-riffle was sufficient enough to reduce the pronounced high-velocity jet. In general this modeling simulation illustrated the importance of riffle entrance incline slope per deeper pre-riffle pool to dissipate flow jets, but further research could lead to more specific restoration design criteria.

Finally, the River2D model was used to investigate shear stress reversal by comparing shear velocity $\left(\mathbf{u}_{*}\right)$ as the model output parameter between low- and high-flow stages. Per visual inspection, it is apparent with the final channel design with expanded widths at riffles and preriffle pools, bed shear stress reversal occurs (Fig. 9). During the low-flow stage, u* was greater in the riffles than the pools, approximately $0.05-0.08 \mathrm{~m} / \mathrm{s}$ and $0.03 \mathrm{~m} / \mathrm{s}$, respectively. During high-flow stage, $\mathrm{u} *$ was greater in the pools than the riffles, approximately $0.08-0.10 \mathrm{~m} / \mathrm{s}$ and 0.04-0.07 m/s, respectively.

In addition to justifying riffle-pool maintenance flows per shear stress reversal, $\mathrm{u}_{*}$ was used to compute $\tau_{0}$ in order to 1 ) identify potential areas prone to scour and 2) size gravel material for the engineered riffles. Through this mapping exercise, locations of high $\tau_{0}$ greater than fieldmeasured bank $\tau_{\mathrm{c}}$ identified bank areas that may need scour protection, e.g., toe rock and root wads. Per inspection of the River2D model output, the maximum $\mathrm{u} *$ on the bed and bank were 
$0.135 \mathrm{~m} / \mathrm{s}$ and $0.08 \mathrm{~m} / \mathrm{s}$, equating to a $\tau_{0}$ of $18.2 \mathrm{~Pa}$ and $6.4 \mathrm{~Pa}$, respectively (Fig. 9). The measured bank $\tau_{\mathrm{c}}$ from the jet test device was 3.8 Pa, indicating some locations on the bank needed scour protection. These vulnerable locations to erosion required engineering judgment by either 1) modifying the design morphology, and/or 2) incorporating a root wad structure into the bank. From River2D, the maximum bed $\tau_{0}$ of $18.2 \mathrm{~Pa}$ and using the Shields diagram (Sturm, 2010), a minimum gravel diameter of $2.5 \mathrm{~cm}$ for incipient motion was estimated. The gravel size specified for riffle construction was $3.8 \mathrm{~cm}$ diameter. The shear velocity plot provided a useful tool assessing stream restoration designs for local channel stability, and estimating imported rock size for riffle beds.

\subsubsection{Ecohydraulic Modeling Approach to Support Restoration Design}

Background. River2D incorporates a habitat module using PHABSIM methodology that computes weighted usable areas (WUAs) per stream surface area (Bovee et al., 1998; Blackburn and Steffler, 2002). WUAs are based on a combination of hydraulic (velocity and depth) and substrate characteristics, multiplied by the composite probability of use per fish or other aquatic biota. Probabilities are referred to as habitat suitability indices (HSI) and are associated with species' habitat quality preferences for velocity, depth, and substrate type. The hydraulics module in River2D provides the habitat module with water depth and depth-average velocity per finite element cells. Two additional input files are needed to run the habitat module; they are the channel index file defined by the user a numeric code for substrate types (e.g., clay/silt $=1$, sand $=2$, gravel $=3$; cobble $=4$; bank cover $=6$, and rock $=7$ ). A second file consists of HSI species preferences ranging from 0 to $1(0=$ no preference, $1=$ full preference $)$. Fish HSI are typically obtained through field studies using pre-positioned areal electrofishing devices (Schwartz and Herricks, 2004; Zale et al., 2013). If not collected individually, HSI data can be found in reports 
from the U.S. Fish \& Wildlife Service, Instream Flow Incremental Methodology (IFIM) studies by power companies, consulting firms, and other agency sources.

Method. Computing WUAs for three fish species, WUAs were compared between the original channel and final design morphologies to ecologically assess potential improvements in biotic integrity by adding riffle-pool structures. Computations were conducted for stream discharges of $0.5 \mathrm{~m}^{3} / \mathrm{s}$ (low-flow) and $4.0 \mathrm{~m}^{3} / \mathrm{s}$ (high-flow). The fish species included rock bass (Ambloplites rupestris) a pool-orientated species, greenside darter (Etheostoma blenniodes) a riffle-orientated species, and northern hogsucker (Hypentelium nigricans) a habitat generalist were selected, and per Sain (2006) all species reside in the Beaver Creek watershed. HSI relationships for velocity, depth, and channel substrate for these three species were obtained from Payne (2008) based on field studies from the southern Appalachian region.

Results. WUAs increased from the original channel to the designed channel for both low- and high-flow stages, and all fish, expect for rock bass at low-flow stages (Table 1). The greatest increase in WUAs was for the greenside darter, which correlates with the added riffles structures not present in the original channel (Fig. 10). Per Table 1, River2D results indicated rock bass habitat, as pool habitat could be added to the design. The results also indicated that the new riffle structures provide the northern hogsucker with high-flow refugia (Fig. 11).

River2D is a useful tool to examine how proposed design morphologies may influence improvement of habitat quality relatively. Spatially-displayed WUAs locate areas that could be enhanced through channel morphological modifications. This process constitutes the ecohydraulic component of the overall stream restoration design process. One must caution the interpretation of the results, in that model WUAs only indicates the availability of quality habitat and not whether a fish species will ultimately occupy newly constructed habitat. Watershed 
biological surveys provide important information of the recolonization potential of a restoration site (Nienhuis et al., 2002). Sain (2006) provided that information in Beaver Creek indicating a diversity of fish species had access to the study site for recolonization. Overall this design process remains qualitative, in that the model generates WUAs showing relative improvements from a proposed design, but knowing what the target WUAs should be requires additional species-specific research.

\subsection{Summary: Ecohydraulic Design Integration}

The ecohydraulic approach for stream restoration design integrated various lotic ecology concepts concurrently with physical-based techniques. The physical-based techniques applied geomorphic and hydraulic principles for a stable riffle-pool design understanding constraints imposed by a straight urban stream. It is assumed that by adding riffle-pool structures biotic integrity will only be incrementally improved recognizing urbanizing streams cannot be returned to a pristine, equilibrium state.

Through the experimental CFD modeling efforts completed in this study, it appears that selfmaintaining riffle-pool structures can be achieved in planform-constrained urban streams by: 1) expanding the channel width and removing bank trees at riffle locations resulting in high-flow deceleration and bed shear stress reduction compared with pools; 2) deepening the upstream pool prior to riffle to reduce formation of a concentrated thalweg jet into the riffle, and promote energy dispersion; 3) preserving the existing narrow channel with bank trees promotes flow acceleration for pool maintenance; and 4) installing bank protection at modeled locations of excessive boundary shear stress, generally located at the riffle exit (Fig. 12).

Riffle and pools are critical habitat features where stream biota have evolved and developed life histories to specifically exploit its space and tropic resources necessary for survival (Poff et 
al., 1997; Schwartz, 2002). Ecologically, riffles provide habitat for benthic macroinvertebrates, the food generators for various omnivore and insectivore fish species (Vannote et al., 1980; Allen and Castillo, 2007). Riffles within $2^{\text {nd }}-$ to $3^{\text {rd }}$-order streams commonly will form leaf packs at larger rocks or wood on the stream bed, providing macroinvertebrate's their food source. Therefore in addition to specifying placement of $3.8-\mathrm{cm}$ gravel substrate in the riffle design, 12- to 18-cm sized cobble was specified for on top of the gravel for leaf pack development and ecosystem enhancement.

The ecohydraulic design approach considered the biological resource needs at multiple flow stages, which was applied by a PHABSIM approach using the River2D habitat module. Broadly, this design element applied the patch dynamic concept, where habitats are recognized as a mosaic of temporarily-variable space primarily governed by fluctuating flow stages (Pringle et al., 1988; Thorp et al., 2006). The key design application is to provide for hydraulic habitat diversity, which ecological theory suggests patchiness promotes a more diverse and healthy ecosystem (Lake, 2000). Riffle-pool structures are mesohabitat patches varying in ecological function by flow stage. During low-flow stages, pools provide rearing and feeding habitat, and use is partitioned by hydraulics (Schwartz and Herricks, 2008). Riffle morphology at high-flow stages provides hydraulic refugia during flood events (Schwartz and Herricks, 2005), and as shown in Figures 8 and 11 the new riffle design provides that refugia. Microhabitat patches during low flow include the riffle cobble and pool-riffle root wads. Ecological criteria are placebased and will vary depending by ecoregion, and because stream ecosystems are naturally variable its application for restoration design becomes a qualitative process (Palmer et al., 2005). However by the use of computed WUAs, ecological design for stream restoration can be advanced quantitatively. 


\section{Project Construction}

The final riffle-pool design that was constructed consisted of a 270-m reach with four riffle structures approximately spaced 35-49 m apart, based on the general criteria of 5-7 bankfull widths. However, the available vertical drop in the low-gradient reach presented a design constraint so that a backwater from one riffle would not reach the adjacent upstream riffle. With the overall gradient and a 7-cm drop across the riffle, four riffles could be fitted into the project reach. Riffle locations were also selected based on existing bank tree configurations utilizing them as bank protectors at riffle-pool transition areas (Fig. 12). Geolift banks were constructed with coir matting and native soils at 3:1 side-slopes, and seeded with grass and planted with willow stakes. Root wads were installed at locations with excessive shear stress as identified from River2D, and using on-site trees. Within the riffle bed, $3.8 \mathrm{~cm}$ gravel was placed for the alluvial veneer layer approximately $15-20 \mathrm{~cm}$ thick. Cobble rock $12-18 \mathrm{~cm}$ in diameter were placed on the riffle gravel, and spaced 1-2 m apart to create bed structure for leaf pack generation (Fig. 13). Project construction began in October 2010, and was completed March 2011.

\section{Project Monitoring}

The main focus of this case study was the development of an ecohydraulic design for rifflepool structures in urban streams through CFD modeling, followed by construction of the proposed design. Baseline monitoring was obtained for use in the design as described above. Post-construction monitoring and assessment was implemented, but at this time does not constitute enough data for a statistical analysis of geomorphic and biological differences from baseline data. It only represents a preliminary assessment after one-year post construction with two primary objectives: 1) to identify if the project riffle structures remained stable over the first year after installment, and 2) report qualitatively on biota metric trends post-project construction. 
Continued site monitoring is on-going for the accrual of long-term data so that a statistically valid analysis can be conducted as part of future research.

\subsection{Geomorphic Surveys and Hydrology}

In March 2012, immediately following completion of project construction, representative cross-sections of both the riffle and pool sections were surveyed between permanent rebar datum monuments. In April 2013 these cross-sections were resurveyed to identify whether any major adjustments in channel form has occurred in response to hydrologic events over this period. Cross-sections were surveyed with a Trimble total station and Recon data logger.

Stage data were recorded between March 2012 and April 2013 utilizing a Global Water ${ }^{\mathrm{TM}}$ WL400 Level Sensor. Review of the stage data indicated over the bank floodplain inundation for eight hydrologic events. Even with this excessive number of bankfull events (> 1-2 events per year), cross-sectional form was relatively stable among all cross-sections with no apparent indications of fluvial erosion or bed aggradation (Fig. 14).

\subsection{Biological Surveys}

Tennessee, like most U.S. states, relies on biotic integrity indicators to determine whether a stream is water quality impaired or not based on benthic macroinvertebrate samples (Barbour et al., 1999). The Tennessee Macroinvertebrate Index (TMI) utilizes a semi-quantitative single habitat survey (SQKICK) to measure biometrics based guild community structure, and both tolerant and intolerant species (TDEC, 2011). Biometrics expected to decrease with increased pollution and/or habitat degradation include: total taxa richness (TR), Ephemeroptera Plecoptera Trichoptera richness (EPT-Tax), EPT abundance excluding Cheumatopsyche (\%EPT-Cheum), and percent contribution of organisms that build fixed retreats or have adaptations to attach to surfaces in flowing waters (\%ClingP). Biometrics expected to increase with increased 
degradation include: percent Oligochaetes and Chironomids (\%OC), North Carolina Biotic Index (NCBI), and percent Tennessee nutrient tolerant organisms (\% TNutol).

In July 2009 a SQKICK sampling effort was completed at the restoration site prior to any construction activities. In August 2012 and 2013 after project construction, SQKICK sampling efforts were conducted by Knox County Stormwater Engineering Department. Comparison of these surveys generally showed a slight improvement in both intolerant and tolerant metrics (Table 2). EPT-Tax increased from 3 to 6 species from pre- to post-construction however remains impaired after restoration where 9 species is the score for reference streams. The NCBI and \% TNutol showed an improvement with an increase in intolerant species, to a level indicating partial supporting. Although this assessment only represents a one-year period, the lack of significant improvements may be due to the eight bankfull events repeatedly disturbing the benthic macroinvertebrate community and/or continued excessive fine sediment transport from upstream sources.

The fish Index of Biotic Integrity (IBI) is a biological survey also developed to measure biotic integrity of streams and it is based on 12 sub-index scores (Sain, 2006). IBI sub-indices expected to increase with decreased pollution and/or habitat degradation include: number of native fish species, number of darter species, number of sunfish species, number of sucker species, number of intolerant species, percent specialized insectivores, and percent piscivores. IBI sub-indices expected to increase with increased degradation include percent tolerant species, percent omnivores and stoneroller species, percent hybrids, and percent anomalies. In January 2010 and September 2013, IBI collections were completed by TDEC personnel at the restoration site pre- and post-construction, respectively (Table 3). Comparison of the two surveys indicates incremental improvements in fish community diversity increasing taxa richness from 10 to 16 , 
however below the reference stream score of 42 . The taxa increase included one darter species, and rock bass (sunfish species). As observed in Schwartz and Herricks (2007), habitat enhancement without water quality improvements generally lead to increased species, but mostly tolerant species. The increased omnivores and stoneroller score was likely due to the open tree canopy above the new riffle structures increasing periphyton growth. Per field inspection in April 2013, excessive periphyton growth was not observed. In general, more long-term data is needed to assess the ecological response from the newly constructed riffle-pool structures.

\section{Restoration Implications and Conclusions}

The riffle-pool design developed in this study and pilot project constructed from the design demonstrated as a case study that urban stream habitat can potentially be rehabilitated with incremental improvements in biotic integrity. This case study also demonstrated to stream restoration practitioners a methodological design approach founded in ecological engineering

principles. Considering hydromodification disrupts an urban channel's dynamic equilibrium and stability, it is suggested that use of geomorphic and hydraulic principles rather than an anti-log approach is more applicable for mesohabitat design in urbanizing streams. River2D modeling provided key information that a practitioner can use to assess channel stability, integrated with field measurements of critical shear stress on the banks and bedload transport characteristics. In addition as an ecohydraulic design approach, River2D modeling incorporated a pre-construction assessment of habitat quality, integrating fluvial geomorphology, hydraulics, and ecological data. Because of the stressed environmental condition of urban streams, including a host of multistressors i.e., poor water quality, habitat alteration and sedimentation, and invasive species, innovative approaches for stream restoration are necessary to enhance healthy ecosystems to the 
maximum extent possible. Knowledge gained from this case study will be applied to future research investigating sustainable geomorphic and ecological processes.

\section{Acknowledgements}

Funding to construct the project came from a Tennessee Department of Agriculture 319 grant. The various theses and modeling work were funded by multiple sources including: USGS 104(b) WRRI Grant through the Tennessee Water Resources Research Center (TWRRC); Tennessee Department of Environment and Conservation WMREI Funds; USDA National Sedimentation Laboratory, and US Department of Energy Oak Ridge National Laboratory. Stream restoration project logistics were assisted by Tim Gangaware and Roy Arthur (TWRRC); and Greg Babbit and Patrick McMahon (EcoFlow Consultants). Design and contracting support was provided by Knox County Stormwater Engineering Department, with the aid of Andrew Dodson and Michael Hamrick. Field work assistance included William Cantrell, Tara Mallsion, Lee Mauney, Brady McPherson, many other UTK students, and Knox County AmeriCorps Volunteers. Appreciation is expressed to Drs. Edwin Herricks, Bruce Rhoads, and Marcelo Garcia at the University of Illinois, Urbana for sharing their knowledge on ideas to improve stream naturalization design.

\section{References}

Aadland, L.P. 1993, Stream habitat types: their fish assemblages and relationship to flow. North American Journal of Fisheries Management 13, 790-806.

Allan, J.D.; Castillo, M.M. 2007. Stream Ecology: Structure and Function of Running Waters. Springer Publ.

Annable, W.K.; Watson, C.C.; Thompson, P.J. 2012. Quasi-equilibrium conditions of urban gravel-bed stream channels in southern Ontario, Canada. Regulated Rivers 28, 302-325. 
Barbour, M.T., Gerritsen, J., Snyder B.D., and Stribling, J.B., 1999. Rapid Bioassessment

Protocols for Use in Streams and Wadeable Rivers. EPA 841-B-99-002. U.S. Environmental Protection Agency, Office of Water, Washington D.C.

Bernhardt, E.S.; Palmer, M.A. 2007. Restoring streams in an urbanizing world. Freshwater Biology 52, 738-751.

Blackburn, J.; Steffler, P. 2002. River2D, Two-dimensional Depth Averaged Model of River Hydrodynamics and Fish Habitat, River2D Tutorial Fish Habitat Tools, University of Alberta, Canada.

Bledsoe, B.P.; Stein, E.D.; Hawley, R.J.; Booth, D. 2012. Framework and tool for rapid assessment of stream susceptibility to hydromodification. Journal of the American Water Resources Association 48, 788-808.

Bledsoe, B.P.; Watson, C.C. 2001. Effects of urbanization on channel stability. Journal of the American Water Resources Assocation 37, 255-270.

Bockelmann, B.N.; Fenrich, E.K.; Lin, B.; Falconer, R.A. 2004. Development of ecohydraulics model for stream restoration and river restoration. J. Ecological Engineering 22, 227-235.

Booker, D.J.; Dunbar, M.J. 2004. Application of physical habitat simulation (PHABSIM) modelling to modified urban river channels. River Research and Applications 20, 167-183.

Booth, D.B.; Jackson, C.R. 1997. Urbanization of aquatic systems - degradation thresholds, stormwater detection, and the limits of mitigation. Journal of the American Water Resources Association 33, 1077-1090.

Bovee, K.D.; Lamb, B.L.; Bartholow, J.M.; Stalnaker, C.B.; Taylor, J.; Henroksen, J. 1998. Stream Habitat Analysis Using the Instream Flow Incremental Methodology. US Geological 
Survey, Biological Resources Division Information and Technology Report. USGS/BRD1998-0004.

Bunte, K.; Abt, S.R.; Polondy, J.P.; Ryan, S.E. 2004. Measurement of coarse gravel and cobble transport using portable bedload traps. ASCE J. Hydraulic Engineering 130(9), 879-893.

Cantrell, W. 2009. Method of Evaluation for Stream Bed Shear Stress and Sediment Transport Capacity in Urbanizing Watershed: Implications for Stream Restoration. MS Thesis, University of Tennessee, Knoxville.

Cao, Z.; Carling, P.; Oakley, R. 2003. Flow reversal over a natural pool-riffle sequence: a computational study. Earth Surface Processes \& Landforms 28, 689-705.

Carling, P.A.; Wood, N. 1994. Simulation of flow over pool-riffle topography: A consideration of the velocity reversal hypothesis. Earth Surface Processes \& Landforms 19, 319-322.

Cianfrani, C.M.; Hession, W.C.; Rizzo, D.M. 2006. Watershed imperviousness impacts on channel condition in southeastern Pennsylvania. Journal of the American Water Resources Association 42, 941-956.

Clark, L.A.; Wynn, T.M. 2007. Methods for determining streambank critical shear stress and soil erodibility: implications for erosion rate predictions. Trans. ASABE 50, 95-106.

Clifford, N.J. 1993. Differential bed sedimentology and the maintenance of riffle-pool sequences. Catena 20, 447-468.

Clifford, N.J.; Harmar, O.P.; Harvey, G.; Petts, G.E. 2006. Physical habitat, ecohydraulics and river design: a review and re-evaluation of some popular concepts and methods. Aquatic Conservation: Marine and Freshwater Ecosystems 16, 389-408.

Colosimo, M.F.; Wilcock, P.R. 2007. Alluvial sedimentation and erosion in an urbanizing watershed, Gwynns Falls, Maryland. J. Am. Water Resources Association 43, 499-521. 
De Almeida, G.A.M.; Rodriguez, J.F. 2011. Understanding pool-riffle dynamics through continuous morphological simulations. Water Resources Research 47, 1-15.

Dietrich, W.E. 1987. Mechanics of flow and sediment transport in river bends. In: Richards K. (ed.), River Channel Environment and Process: Basil Blackwell Publ.

Doyle, M.W.; Shields, F.D.; Boyd, K.; Skidmore, P.B.; Dominick, D. 2007. Channel-forming discharge selection in river restoration design. ASCE Journal of Hydrualic Engineering 133(7), 831-837.

Dworak, F.J. 2005. Characterizing Turbulence Structure along Woody Vegetated Banks in Incised Channels: Implications for Stream Restoration. MS Thesis, University of Tennnesse Knoxville.

Emery, J.C.; Gurnell, A.M.; Clifford, N.J.; Petts, G.E.; Morrissey, I.P.; Soar, P.J. 2003. Classifying the hydraulic performance of riffle-pool bedforms for habitat assessment and river rehabilitation design. River Research and Applications 19, 553-549.

Ernst, A.G.; Baldigo, B.P.; Mulvihill, C.I. 2010. Effects of natural-channel design restoration on habitat quality in Catskill Mountain streams, New York. Transactions of the American Fisheries Society 139, 468-482.

Fitzpatrick, F.A.; Harris, M.A.; Arnold, T.L.; Richards, K.D. 2004. Urbanization influences on aquatic communities in northwestern Illinois streams. Journal of the American Water Resources Association 40, 461-475.

Frothingham, K.M.; Rhoads, B.L. 2003. Three-dimensional flow structure and channel change in an asymmetric compound meander loop, Embarras River, Illinois. Earth Surface Processes \& Landforms. 28, 625-644. 
Ghanem, A.; Steffler, P.; Hicks, F.; Katopodis, C. 1996. Two-dimensional hydraulic simulation of physical habitat conditions in flowing streams. Regulated Rivers: Research and Management 12, 185-200.

Gregory, K.J.; Gurnell, A.M.; Hill, C.T.; Toooth, S. 1994. Stability of the pool-riffle sequence in changing river channels. Regulated Rivers: Research and Management 9, 35-43.

Hanson, G.J. 1990. Surface erodibility of earthen channels at high stresses. Part II - Developing an in situ testing device. Trans. ASAE 33, 132-137.

Harper, D.; Ebrahimnezhad, M.; Cot, F.C.I. 1998. Artificial riffles in river rehabilitation: setting the goals and measuring the successes. Aquatic Conserv: Mar Freshw Ecosyst. 8, 5-16.

Heritage, G.; Milan, D. 2004. A conceptual model of the role of excess energy in the maintenance of a riffle-pool sequence. Catena 58, 235-257.

Hession, C.W.; Pizzuto, J.E.; Johnson, T.E.; Horwitz, R.J. 2003. Influence of bank vegetation on channel morphology in rural and urban watersheds. Geology 31, 147-150.

Hey, R.D. 2006. Fluvial geomorphological methodology for natural stable channel design. Journal of the American Water Resources Association 42 (2), 357-374.

Hey, R.D.; Thorne, C.R. 1986. Stable channels with mobile gravel beds. ASCE Journal of Hydraulic Engineering 112, 671-689.

Jennings, D.B.; Jarnagin, S.T. 2002. Changes in anthropogenic impervious surfaces, precipitation and daily streamflow discharge: a historical perspective in a mid-Atlantic subwatershed. Landscape Ecology 17, 471-489.

Johnson, P.A.; Fecko, B.J. 2008. Regional channel geometry equations: a statsitical comparison for physiographic provinces in the eastern US. River Research and Applications 24, 823-834. 
Kang, R.S.; Marston, R.A. 2006. Geomorphic effects of rural-to-urban land use conversion on three streams in the Central Redbed Plains of Oklahoma. Geomorphology 79, 488-506.

Keck, B.P.; Marion, Z.H.; Martin, D.J.; Kaufman, J.C.; Harden, C.P.; Schwartz, J.S.; and Strange, R.J. 2014. Fish functional traits correlated with environmental traits in a temperate biodiversity hot spot. PLoS One 9(3), e93237. DOI: 10.1371/journal.pone.0093237.

Keller, E.A.; Florsheim, J.L. 1993. Velocity-reversal hypothesis: a model approach. Earth Surface Processes and Landforms 18, 733-740.

Keller, E.A.; Melhorn, W.N. 1978. Rhythmic spacing and origin of pools and riffles. Geological Society of America Bulletin 89, 723-730.

Knighton, D. 1998. Fluvial Forms and Processes: A New Perspective: Arnold Publ., London.

Lane, S.N.; Biron, P.M.; Bradbrook, K.F.; Butler, J.B.; Chandler, J.H.; Crowell, M.D.; McLelland, S.J.; Richards, K.S.; Roy, A.G. 1998. Three-dimensional measurement of river channel flow processes using acoustic Doppler velocimetry. Earth Surface Processes and Landforms 23, 1247-1267.

Lake, P.S. 2000. Disturbance, patchiness, and diversity in streams. Journal of the North American Benthological Society 19(4), 573-592.

Lamarre, H.; Roy, A.G. 2005. Reach scale variability of turbulent flow charactertstics in a gravel-bed river. Geomorphology 68, 95-113.

Lamouroux, N.; Poff, N.L.; Angermeier, P.L. 2002. Intercontinental convergence of fish community traits along geomorphic and hydraulic gradients. Ecology 83, 1792-1807.

Lawless, M.; Robert, A. 2011. Three-dimensional flow structure around small-scale bedforms in a simulated gravel-bed environment. Earth Surface Processes and Landforms 26, 507-522. 
Lisle, T. 1979. A sorting mechanism for a riffle-pool sequence: Summary. Geological Society of America Bulletin, Part I. 90, 616-617.

Ma, L.; Ashworth, P.J.; Best, J.L.; Elliott, L.; Ingham, D.B.; Whitcombe, L.J. 2002. Computational fluid dynamics and the physical modeling of an upland urban river. Geomorphology 44, 375-391.

Mallison, T.L. 2008. Comparing In Situ Submerged Jet Test Device and Laboratory Flume Methods to Estimate Erosional Properties of Cohesive Soils for Bank Stability Models. MS Thesis, University of Tennessee, Knoxville.

Matthews, W.J. 1990. Spatial and temporal variation in fishes of riffle habitats: A comparison of analytical approaches for the Roanoke River. Am. Midl. Nat. 124, 31-45.

MacRae, C.R. 1997. Experience from morphological research on Canadian streams: Is control of the two-year frequency runoff event the best basis for stream channel protection? Effects of Watershed Development and Management on Aquatic Ecosystems. L.A. Roesner (ed.). American Society of Civil Engineers, Washington DC.: 144-162.

McBride, M.; Booth, D.B. 2005. Urban impacts on physical stream condition: effects of spatial scale, connectivity, and longitudinal trends. Journal of the American Water Resources Association 41, 565-580.

Millar, R.G. 2004. Theoretical regime equations for mobile gravel-bed rivers with stable banks. Geomorphology 64, 207-220.

Morris, S.; Moses, T. 1999. Urban stream rehabilitation: a design and construction case study. Environmental Management 23, 165-177.

Nagle, G. 2007. Invited commentary for hydrological processes evaluating 'natural channel design' stream projects. Hydrological Processes 21(8), 2539-2545. 
Nelson, J.M.; Shreve, R.I.; McLean, S.R.; Drake, T.G. 1995. Role of near-bed turbulence structure in bedlaod transport and bedform mechanics. Water Resources Research 31(8), 2071-2086.

Newson, M.D.; Newson, C.L. 2000. Geomorphology, ecology and river channel habitat: mesoscale approaches to basin-scale challenges. Progress in Physical Geography 24, 195-217.

Nienhuis, P.H.; Buijse, A.D.; Leuven, R.S.E.W.; Smits, A.J.M.; de Nooij, R.J.W.; Samborska, E.M. 2002. Ecological rehabilitation of the lowland basin of the river Rhine (NW Europe). Hydrobiologia 478, 53-72.

Niezgoda, S.L.; Johnson, P.A. 2005. Improving the urban stream restoration effort: identifying critical form and processes relationships. Environmental Management 35, 579-592.

Niezgoda, S.L.; Johnson, P.A. 2006. Modeling the long term impacts of using rigid structures in stream channel restoration. J. Am. Water Resources Association 42, 1597-1613.

O’Driscoll, M., Clinton, S., Jefferson, A., Manda, A., and McMillan, S. 2010. Urbanization effects on watershed hydrology and in-stream processes in the southern United States. Water 2, 605-648.

Papanicolaou, A.N; Diplas, P.; Darcey, C.L.; Balakishnan, M. 2001. Surface roughness effects in near-bed turbulence: implications to sediment entrainment. ASCE Journal of Engineering Mechanics 127(3), 211-218.

Palmer, M.A.; Bernhardt, E.S.; Allan, J.D.; Lake, P.S.; Alexander, G.; Brooks, S.; Carr, J.; Clayton, S.; Dahm, C.N.; Follstad Shah, J.; Galat, D.L.; Loss, S.G.; Goodwin, P.; Hart, D.D.; Hassett, B.; Jenkinson, R.; Kondolf, G.M.; Lave, R.; Meyer, J.L.; O'Donnell, T.K.; Pagano, L.; Sudduth, E. 2005. Standards for ecologically successful river restoration. Journal of Applied Ecology 42, 208-217. 
Payne, T.R. 2008. Technical Memorandum to Appalachian Power Company; Instream Flow Needs Workgroup - Claytor Project 739-018. Thomas R. Payne \& Associates, Arcata, CA. Paul, M.J.; Meyer, J.L. 2001. Streams in the urban landscape. Annual Review of Ecology and Systematics 32, 333-365.

Poff, N.L. 1997. Landscape filters and species traits: Towards mechanistic understanding and prediction in stream ecology. J. North American Benthological Society 16, 391-409.

Poff, N.L.; Olden, J.D.; Vieira, N.K.M.; Finn, D.S.; Simmons, M.P.; Kondratieff, B.C. 2006. Functional trait niches of North American lotic insects: traits-based ecological applications in light of phylogenetic relationships. J. North American Benthological Society 25, 730-755.

Pringle, C.M.; Naiman, J.R.; Bretschko, G.; Karr, J.R.; Oswood, M.W.; Webster, J.R.; Welcome, R.L.; Winterbourn, M.J. 1988. Patch dynamics in lotic systems: the stream as a mosaic. Journal of the North American Benthological Society 7(4), 503-524.

Rabeni, C.F.; Sowa, S.P. 1996. Integrating biological realism into habitat restoration and conservation strategies for small streams. Can J Fish Aquat Sci. 53, 252-259.

Rhoads, B.L.; Schwartz, J.S.; Porter, S. 2003. Stream geomorphology, bank vegetation, and three-dimensional habitat hydraulics for fish in midwestern agricultural streams. Water Resources Research 39, 1218-1230.

Rhoads, B.L.; Welford, M.R. 1991. Initiation of river meandering. Progress in Physical Geography 15, 127-156.

Richards, K.S. 1976. The morphology of riffle-pool sequences. Earth Surface Lanforms and Processes 1, 71-88.

Rodriguez J.F.; Garcia, M.H. 2008. Laboratory measurements of 3-D flow patterns and turbulence in straight open channel with rough bed. J. Hydraulic Research 46, 454-465. 
Rosgen, D.L. 1996. Applied River Morphology. Wildlands Hydrology, Colorado.

Rosgen, D.L. 2008. DISCUSSION: "Critical evaluation of how the Rosgen classification and associated 'natural channel design' methods fail to integrate and quantify fluvial processes and channel response". Journal of the American Water Resources Association 44, 782-792.

Roy, A.G.; Buffin-Belanger, T.; Lamarre, H.; Kirkbridge, A.D. 2004. Size, shape, and dynamics of large-scale turbulent flow structures in a gravel-bed river. J. Fluid Mechanics 500, 1-27.

Sain, R.L. 2006. Characterizing How Fish Communities and Physical Habitat Structure are Affected by Urbanization in an East Tennessee Watershed. MS Thesis, University of Tennessee, Knoxville.

Schwartz, J.S. 2002. Stream Habitat Characterized by Stage-specific Flows and Threedimensional Geomorphological Complexity: Development of Ecological Criteria for Stream Restoration Design. PhD Dissertation, University of Illinois, Urbana-Champaign.

Schwartz, J.S. 2003. Use of a two-dimensional hydrodynamic model for restoration design of high-flow habitat in low-gradient Midwest streams. Pages 242-251 In M. Clar, D. Carpenter, J. Garcie, and L. Slate (editors). Proceedings of the Symposium on the Protection and Restoration of Urban and Rural Streams, June 23-25, 2003, Philadelphia, PA; American Society of Civil Engineers, Reston, VA.

Schwartz, J.S.; Herricks, E.E. 2004. Use of prepositioned areal electrofishing devices with rod electrodes in small streams. North Am. Journal of Fisheries Management 24, 1330-1340. Schwartz, J.S.; Herricks, E.E. 2005. Fish use of stage-specific fluvial habitats as refuge patches during a flood in a low-gradient Illinois stream. Can J Fish Aquat Sci. 62, 1540-1552. 
Schwartz, J.S.; Herricks, E.E. 2007. Evaluation of pool-riffle naturalization structures on habitat complexity and the fish community in an urban Illinois stream. River Research and Applications 23, 451-466.

Schwartz, J.S.; Herricks, E.E. 2008. Fish use of ecohydraulic-based mesohabitat units in a lowgradient Illinois stream: implications for stream restoration. Aquatic Conservation: Marine and Freshwater Ecosystems.18, 852-866.

Schwartz, J.S.; Herricks, E.E., Rhoads, B.L. 2001. Integrating geomorphology, hydraulics, and ecological criteria to support stream naturalization in East-Central Illinois. ASCE/EWRI World Water and Environmental Resources Congress; Orlando, Florida; May 2001.

Schwartz, J.S.; Neff, K.J. 2011. Use of River2D hydrodynamic model for stream restoration assessment and design. Proceedings of the World Water \& Environmental Resources Congress; Pages 2593-2602. ASCE Environmental and Water Resources Institute, Palm Springs CA; May 22-26, 2011. DOI. 10.1061/41173(414)269.

Schwartz, J.S.; Simon, A.; Klimetz, L. 2011. Use of fish functional traits to associate in-stream suspended sediment transport metrics with biological impairment. Environmental Monitoring and Assessment 179, 347-369.

Sear, D.A. 1996. Sediment transport processes in pool-riffle sequences. Earth Surface Processes \& Landforms 21, 241-262.

Sear, D.A.; Newson, M.D. 2004. The hydraulic impact and performance of a lowland rehabilitation scheme based on pool-riffle installation: The River Waveney, Scole, Suffolk, UK. River Research and Applications 20, 847-863.

Shamloo, H.; Rajaratnam, R.; Katopodis, C. 2002. Hydraulics of simple habitat structures. Journal of Hydraulic Research 39, 351-366. 
Shields, F.D., Copeland, R.R.; Klingeman, P.C.; Doyle, M.W. Simon, A. 2003. Design for stream restoration. ASCE Journal of Hydraulic Engineering 129, 575-584.

Simon, A. 1995. Adjustment and recovery of unstable alluvial channels: Identification and approaches for engineering management. Earth Surfaces Process \& Landforms 20, 611-628.

Simon, A.; Doyle, M.; Kondolf, M.; Shields, F.D.; Rhoads, B.; McPhillips, M. 2007. Critical evaluation of how the Rosgen classification and associated "natural channel design" methods fail to integrate and quantify fluvial processes and channel response. Journal of the American Water Resources Association 43, 1117-1131.

Simon, A.; Hupp, C.R. 1990. The recovery of alluvial systems in response to imposed channel modifications, West Tennessee, USA. Vegetation and Erosion. J.B. Thornes (ed). London, John Wiley \& Sons Ltd.: 145-160.

Simon, A.; Rinaldi, M. 2006. Disturbance, stream incision, and channel evolution: the roles of excess transport capacity and boundary materials in controlling channel response. Geomorphology 79, 361-383.

Slate, L.O.; Shields, F.D.; Schwartz, J.S.; Carpenter, D.D.; Freeman, G. 2007. Engineering design standards and liability for stream channel restoration. ASCE Journal of Hydraulic Engineering 133, 1099-1102.

Smith, S.M.; Prestegaard, K.L. 2005. Hydraulic performance of a morphology-based stream channel design. Water Resources Research 41, doi:10.1029/2004WR003926.

Steffler, P.; Blackburn, J. 2002. River2D, Two-dimensional Depth Averaged Model of River Hydrodynamics and Fish Habitat, Introduction to Depth Averaged Modeling and User's Manual, University of Alberta, Canada.

Sturm, T.W. 2010. Open Channel Hydraulics: McGraw-Hill Publ. 
Tamburrino, A.; Gulliver, J.S. 1999. Large flow structures in tubulent open channel flow. Journal of Hydraulics Research 37(3), 363-380.

TDEC. 2006. EPA Approved Final Version Year 2006 303(d) List. Tennessee Department of Environment and Conservation, Nashville, TN. http:/tn.gov/environment/water/docs/wpc/ $303 d 2006$.

TDEC. 2011. Quality System Standard Operating Procedure for Macroinvertebrate Stream Surveys. Tennessee Department of Environment and Conservation, Nashville.

Thompson, A. 1986. Secondary flows and the pool-riffle unit: a case study of the processes of meander development. Earth Surfures Processes \& Landforms 11, 631-641.

Thorp, J.H.; Thorms, M.C.; Delong, M.D. 2006. The riverine ecosystem synthesis: biocomplexity in river networks across space and time. River Research and Applications 22, 123-147.

Van Bohemen, H.D. 1998. Habitat fragmentation, infrastructure and ecological engineering. Journal of Ecological Engineering 11, 199-207.

Vannote, R.L.; Minshall, G.W.; Cummins, K.W.; Sedell, J.R.; Cushing, C.E. 1980. The river continuum concept. Can J Fish Aquat Sci. 37, 130-137.

Wade, R.J.; Rhoads, B.L.; Rodriguez, J.; Daniels, M.; Wilson, D.; Herricks, E.E.; Bombardelli, F.; Garcia, M.; Schwartz, J.S. 2002. Integrating science and technology to support stream naturalization near Chicago, Illinois. J. Am. Water Resources Association 38, 931-944.

Walsh, C.J.; Fletcher, T.D.; Ladson, A.R. 2005a. Stream restoration in urban catchments through redesigning stormwater systems: looking to the catchment to save the stream. Journal of the North American Benthological Society 24, 690-705. 
Walsh, C.J.; Roy, A.H.; Feminella, J.W.; Cottingham, P.D.; Groffman, P.M.; Morgan II, R.P. 2005b. The urban stream syndrome: current knowledge and the search for a cure. Journal of the North American Benthological Society 24, 706-723.

Wang, L.; Lyons, J.; Kanehl, P. 2001. Impacts of urbanization on stream habitat and fish across multiple spatial scales. Environmental Management 28, 255-266.

Williams, K.H. 2005. Linking channel stability and bed sediment characteristics to biological integrity in Tennessee Ridge and Valley streams. MS Thesis. University of Tennessee, Knoxville.

Wilkinson, S.N.; Keller, R.J.; Rutherfund, I.D. 2004. Phase-shifts in shear stress as an explanation for the maintenance of pool-riffle sequences. Earth Surface Processes \& Landforms 29, 737-753.

Wohl, E. 2005. Compromised rivers: Understanding historical human impacts on rivers in the context of restoration: Ecology and Society 10(2), 2 [online].

Yalin, M.S. 1992. River Mechanics: Pergamon Press Oxford Publ.

Yang, C.T. Formation of riffles and pools. Water Resources Research 7, 1567-1574.

Zale, A.D.; Parish, D.L.; Sutton, T.M. 2013. Fisheries Techniques, $3^{\text {rd }}$ Edition. American Fisheries Society, Bethesda, Maryland. 


\section{Tables}

Table 1. Habitat composite WUAs for low-and high-flow stages comparing the original channel to the design channel morphology with four riffle-pool structures. Three fish species used in the River2D model were: rock bass, greenside darter, and northern hogsucker.

\begin{tabular}{lcccc} 
Channel & Discharge & \multicolumn{3}{c}{ Weighted Usable Area $\left(\mathbf{m}^{\mathbf{2}}\right)$} \\
\cline { 3 - 5 } Morphology & $\left(\mathrm{m}^{3} / \mathrm{s}\right)$ & Rock Bass & Greenside Darter & Northern Hogsucker \\
\hline Original Channel & 0.5 & 17.7 & 34.8 & 318.6 \\
Design Channel & 4.0 & 11.7 & 164.4 & 419.6 \\
\hline Original Channel & 0.5 & 2.7 & 7.5 & 487.7 \\
Design Channel & 4.0 & 6.8 & 132.3 & 714.0 \\
\hline
\end{tabular}

Table 2. Tennessee macroinvertebrate index (TMI) biometric scores for pre- and postconstruction periods at the beaver Creek study site, and TMI reference stream scores.

\begin{tabular}{cccccccc} 
& \multicolumn{7}{c}{ TMI Biometric Scores } \\
Survey Date & TR & EPT-Tax & \%ClingP & \%EPT-Cheum & \%OC & NCBI & \% TNutol \\
\hline July 2009 & 21 & 3 & 45.1 & 16 & 38.3 & 5.68 & 64.2 \\
August 2012 & 21 & 6 & 71.43 & 27.27 & 17.75 & 5.39 & 52.38 \\
August 2013 & 27 & 6 & 51.98 & 20.79 & 57.92 & 5.18 & 45.05 \\
Integrity Trend* & + & + & + & + & $+/-$ & + & + \\
\hline Reference Stream** & $>28$ & $>9$ & $>54.3$ & $>44.7$ & $<27.3$ & $<4.87$ & $<30.1$ \\
\hline
\end{tabular}

* All trends were not statistically significant $(\mathrm{p}<0.05)$ per linear regression.

** TMI scores from TDEC (2011) for Ecoregion 67, greater than 2 square miles drainage area.

Table 3. Fish IBI sub-index scores for pre- and post-construction period site surveys.

\begin{tabular}{lcccc} 
Fish IBI Sub-indices & $\begin{array}{c}\mathbf{1 / 7 / 2 0 1 0} \\
\text { Score }\end{array}$ & $\begin{array}{c}\mathbf{9 / 1 8 / 2 0 1 3} \\
\text { Score }\end{array}$ & $\begin{array}{c}\text { Integrity } \\
\text { Trend }\end{array}$ & $\begin{array}{c}\text { Reference } \\
\text { Stream * }\end{array}$ \\
\hline Number of native fish species & 10 & 16 & + & $>42$ \\
Number of darter species & 3 & 4 & + & $>8$ \\
Number of Sunfish species (excl. Micropterus) & 1 & 3 & + & $>4$ \\
Number of sucker species & 1 & 1 & 0 & $>8$ \\
Number of intolerant species & 2 & 2 & 0 & $>5$ \\
Percent tolerant species & $1 \%$ & $6.7 \%$ & - & $<10 \%$ \\
Percent omnivores and stoneroller species & $20 \%$ & $30.8 \%$ & - & $<10 \%$ \\
Percent specialized insectivores & $54 \%$ & $46.0 \%$ & - & $>50 \%$ \\
Percent piscivores & $7 \%$ & $2.9 \%$ & - & $>4 \%$ \\
Catch Rate (per 300 sq. ft.) & $4 \%$ & na & & varies \\
Percent hybrids & $0 \%$ & $0 \%$ & 0 & $0 \%$ \\
Percent anomalies & $1 \%$ & $0 \%$ & + & $<2 \%$ \\
\hline
\end{tabular}

* IBI Sub-index scores from Tennessee Valley Authority field protocol manual. 


\section{List of Figures}

Fig. 1. Location map of Beaver Creek study site in Knox County, Tennessee. Aerial view from Google Earth ${ }^{\mathrm{TM}}$ (2009) with project site in red box and arrow showing creek flow direction.

Fig. 2. Photos of the $6.5-\mathrm{m}$ wide incised channel showing dense woody vegetation on the banks (left) and flood flow near bankfull (right).

Fig. 3. Topographic rendering of proposed conceptual design for the constructed riffle areas forming hydraulic acceleration-deceleration-acceleration patterns. Model section approximately $104 \mathrm{~m}$ in length and bed and bank topography from site survey.

Fig. 4. Topographic image with trees as vertical cylinders used for the FLOW3D® model boundary.

Fig. 5. FLOW3D modeled maximum velocity magnitude and velocity magnitude vectors illustrated in $\mathrm{y}-\mathrm{z}$ cross-sections in the channel with the bank trees present.

Fig. 6. FLOW3D modeled maximum velocity magnitude and velocity magnitude vectors illustrated in $y-z$ cross-sections in the channel with the restoration design implemented.

Fig. 7. River2D model for original channel topography showing water depth (m) and velocity $(\mathrm{m} / \mathrm{s})$ for a) low-flow $\left(0.5 \mathrm{~m}^{3} / \mathrm{s}\right)$ and b) bankfull flow $\left(4.0 \mathrm{~m}^{3} / \mathrm{s}\right)$.

Fig 8. River2D model for proposed four riffles located at expanded channel width for a) an initial condition with no bed topography modifications at the riffle entrance, and b) a final design condition with deepening of the bed topography at the riffle entrance. Model discharge was bankfull flow at $\left(4.0 \mathrm{~m}^{3} / \mathrm{s}\right)$.

Fig. 9. River2D model for proposed four riffles showing shear velocity $(\mathrm{m} / \mathrm{s})$ for low-flow $(0.5$ $\left.\mathrm{m}^{3} / \mathrm{s}\right)$ and bankfull flow $\left(4.0 \mathrm{~m}^{3} / \mathrm{s}\right)$, and bed shear stress reversal between stages. 
Fig. 10. River2D model for low-flow stage $\left(0.5 \mathrm{~m}^{3} / \mathrm{s}\right)$, habitat composite WUAs for the greenside darter comparing the original channel to the design channel morphology with four riffle-pool structures.

Fig. 11. River2D model for high-flow stage $\left(4.0 \mathrm{~m}^{3} / \mathrm{s}\right)$, habitat composite WUAs for the northern hogsucker for the design channel morphology with four riffle-pool structures.

Fig. 12. Plan view of final riffle design constructed at the study site. Topography contour intervals are $2-\mathrm{ft}$.

Fig. 13. Site photos of a) riffle under construction in October 2010, and completed riffle after one-year following construction completion in April 2012.

Fig. 14. Post-construction monitoring for channel stability at riffle cross-sections conducted in March 2011 and April 2012. 


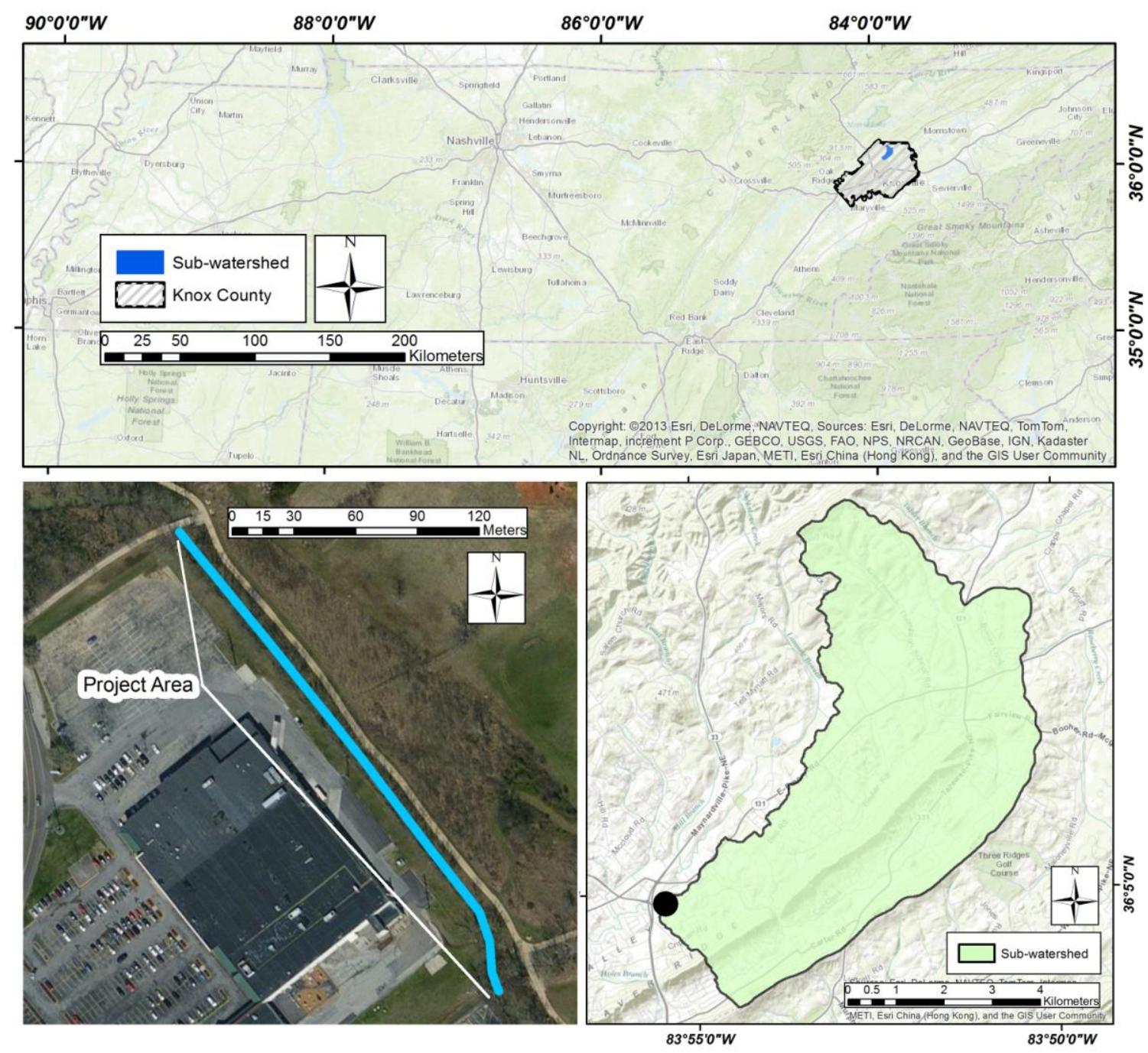

Fig. 1 

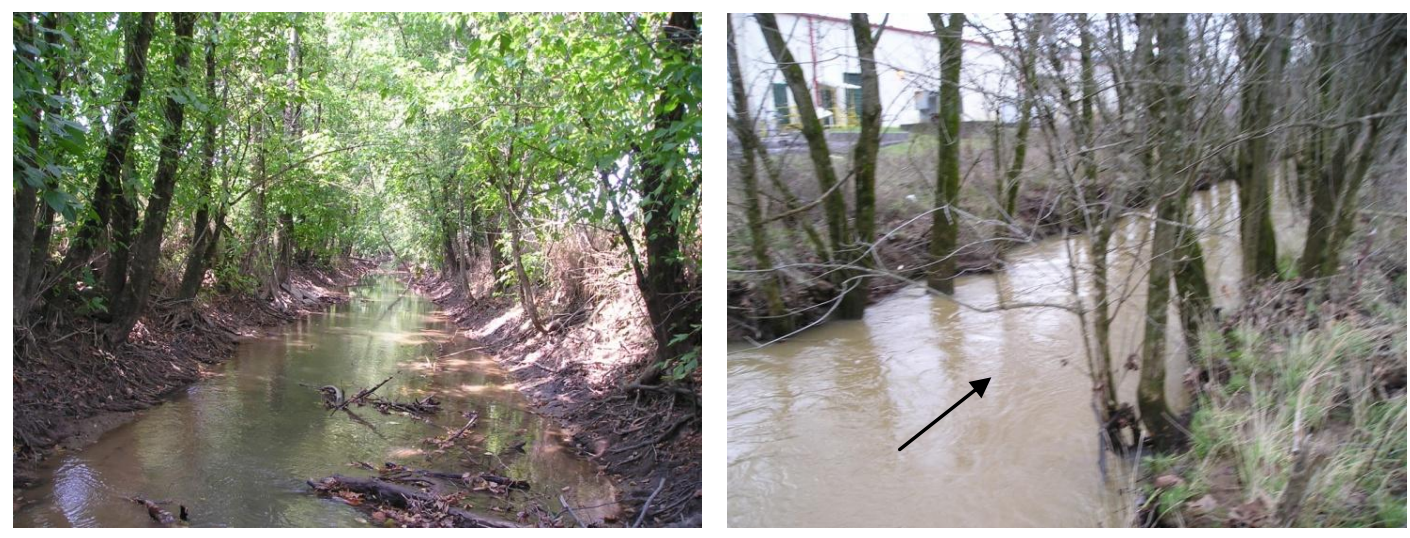

Fig. 2

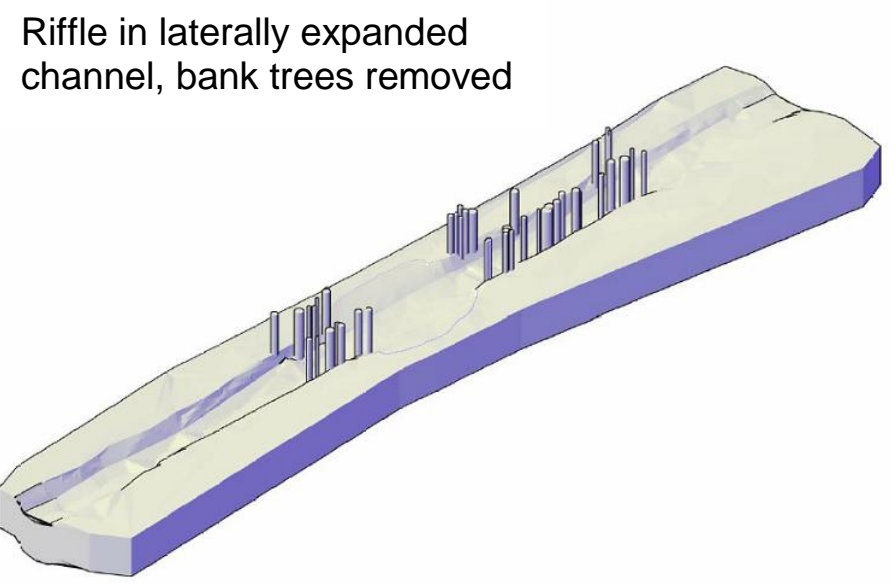

Fig. 3 


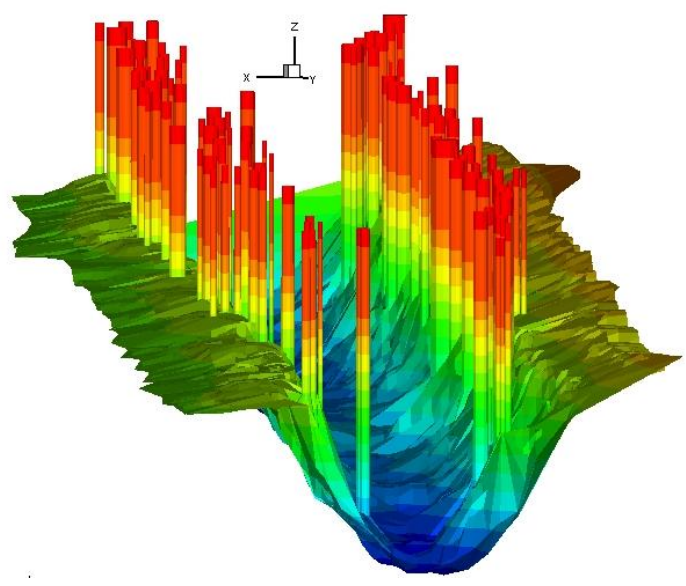

Fig. 4 

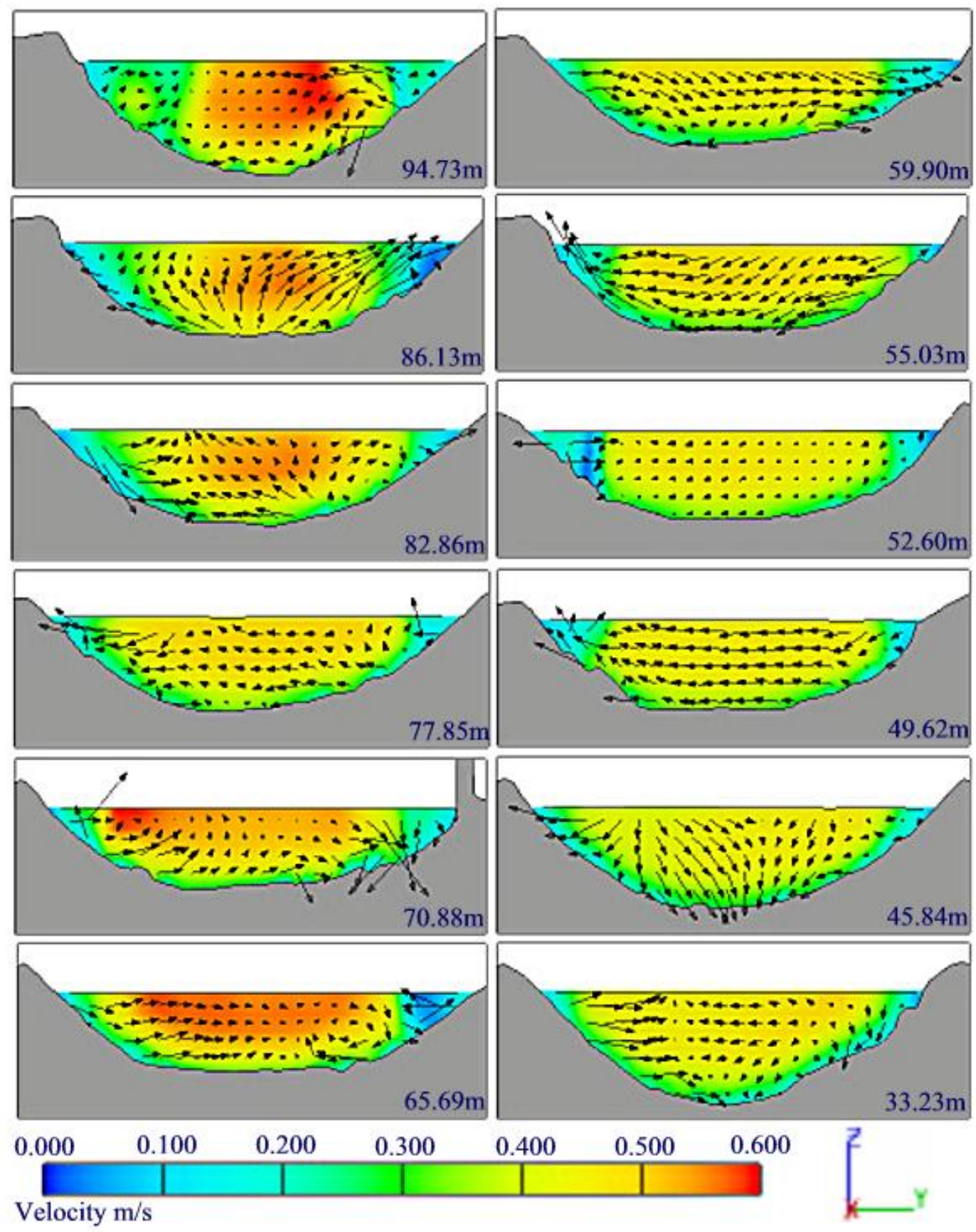

Fig. 5 

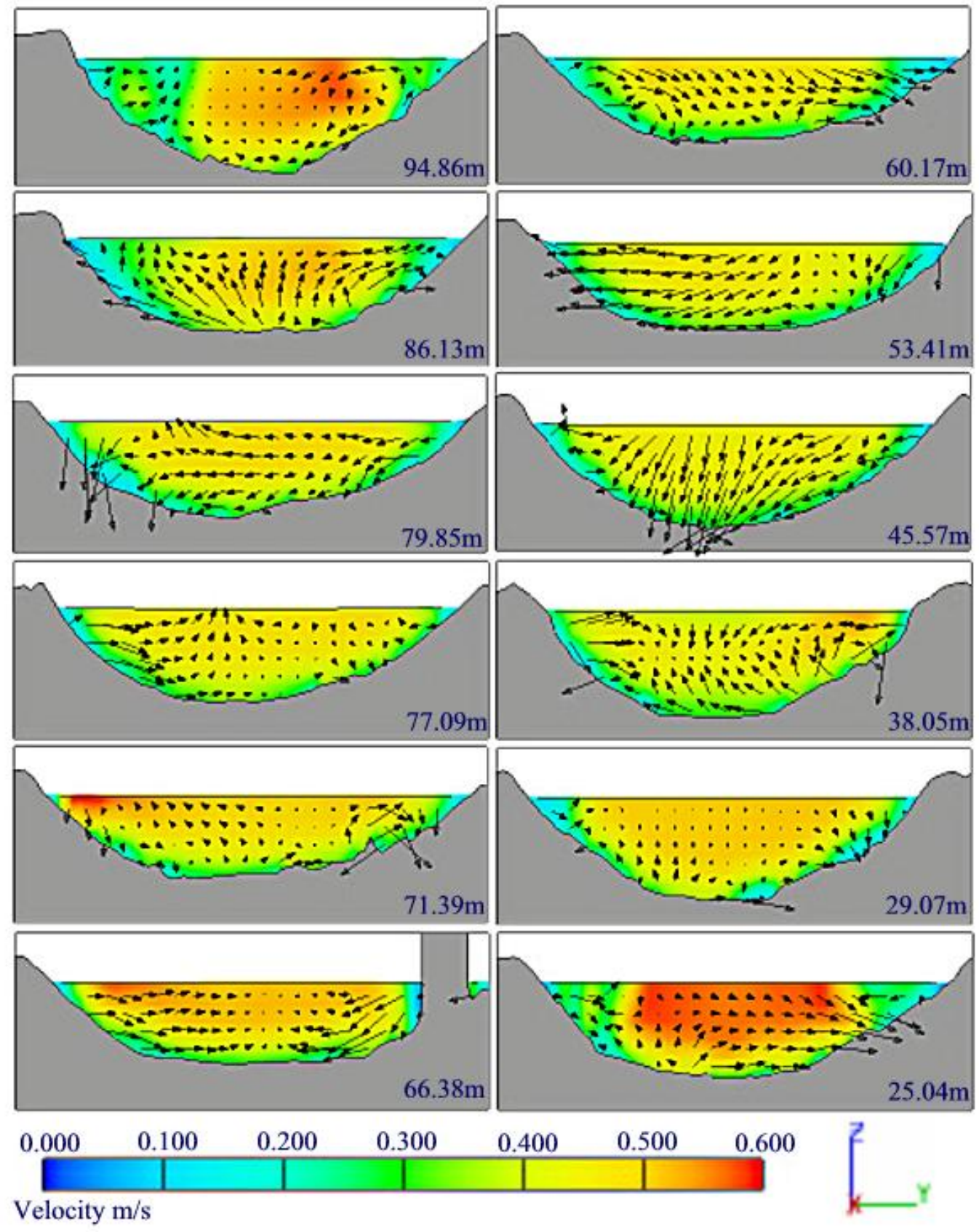

Fig. 6 
a)
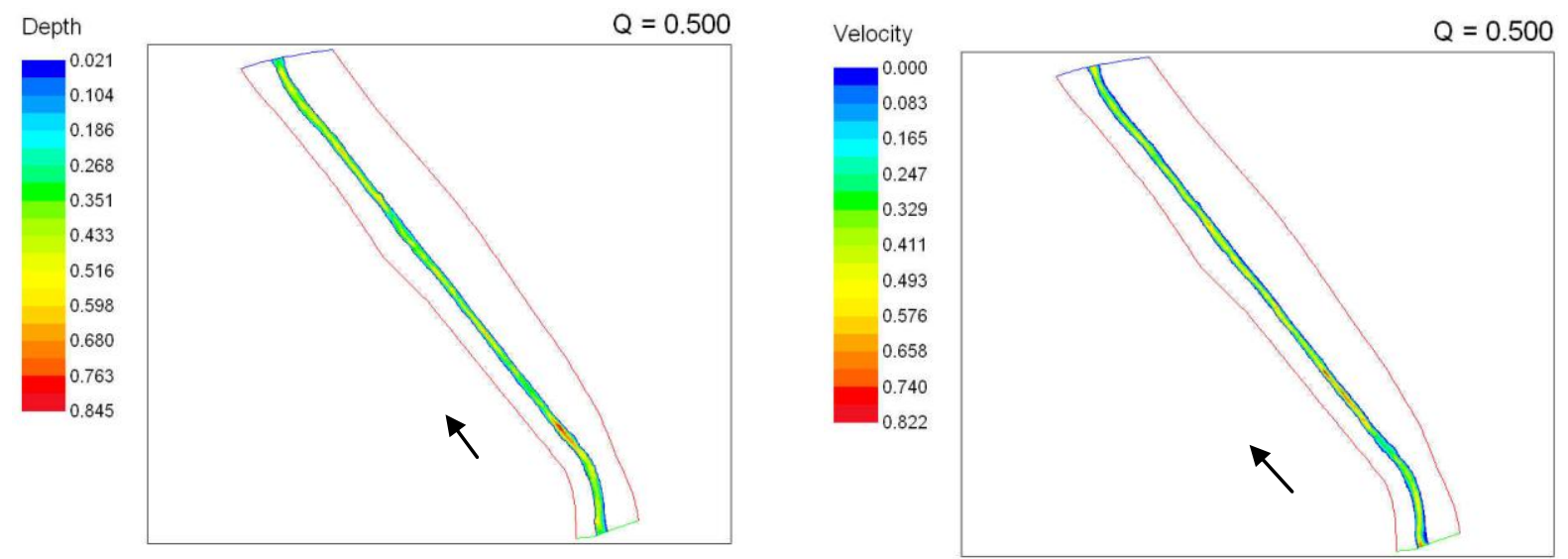

b)
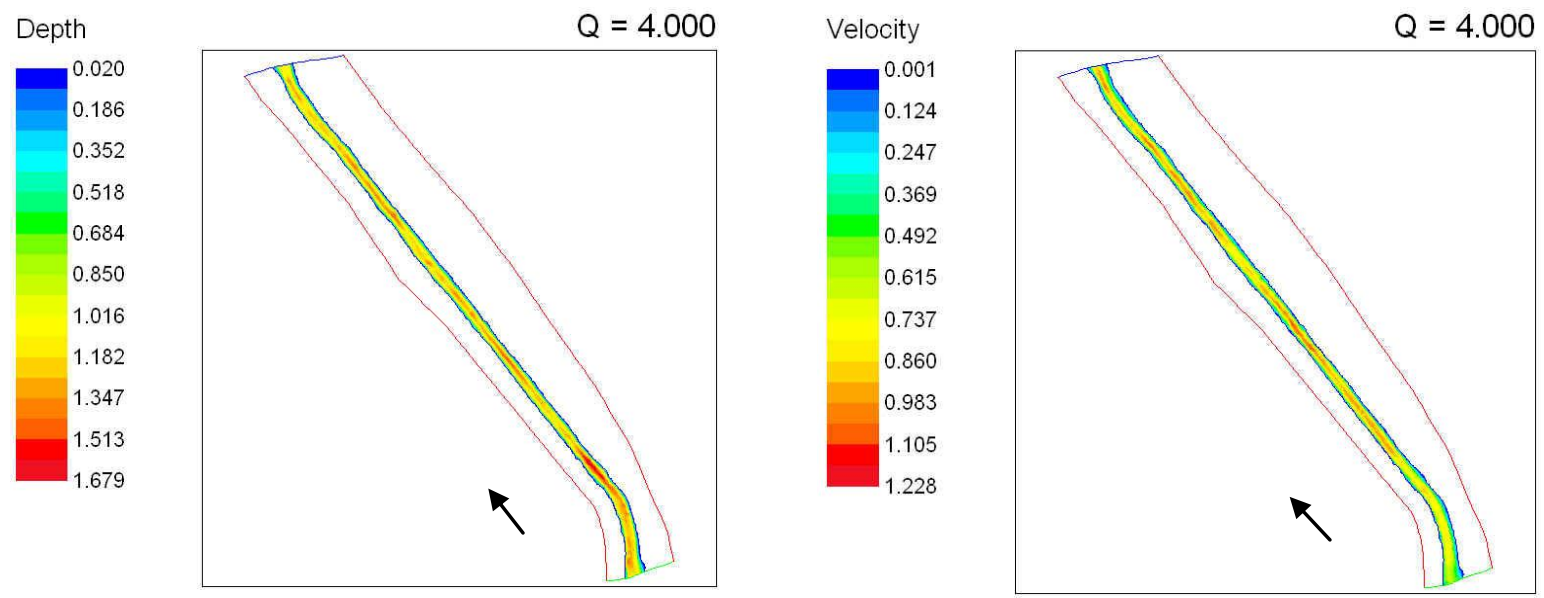

Fig. 7 
a)
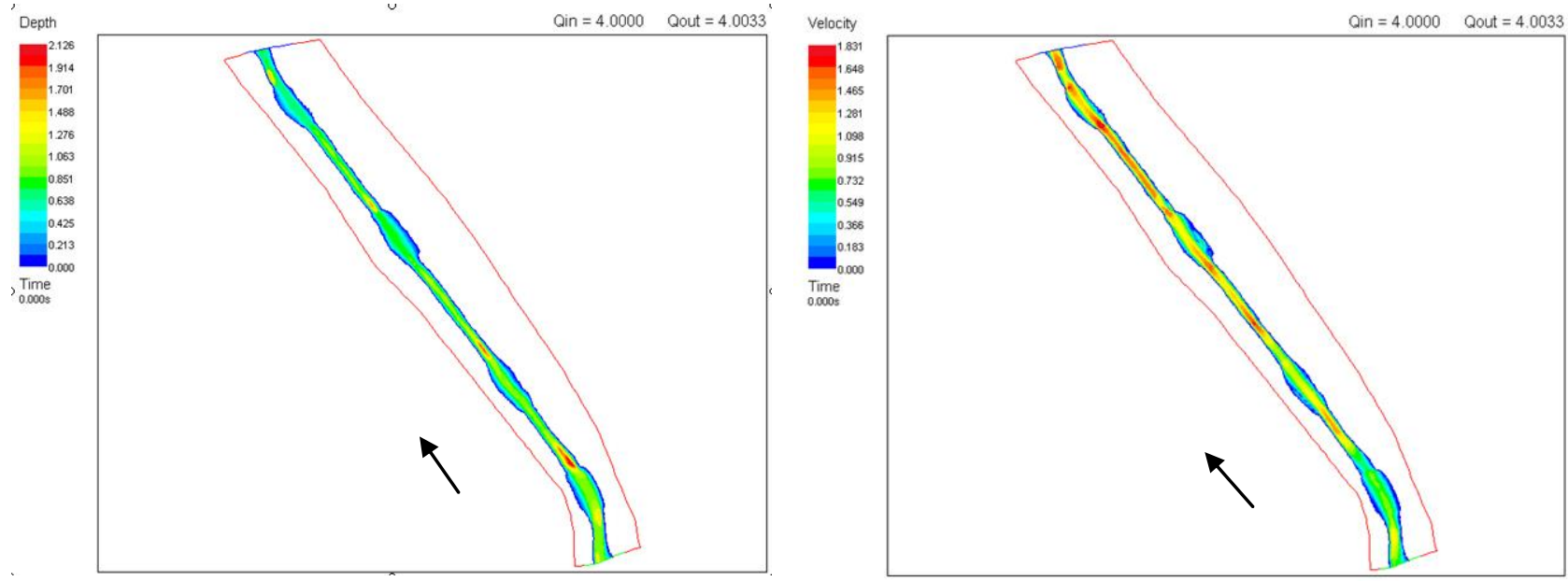

b)
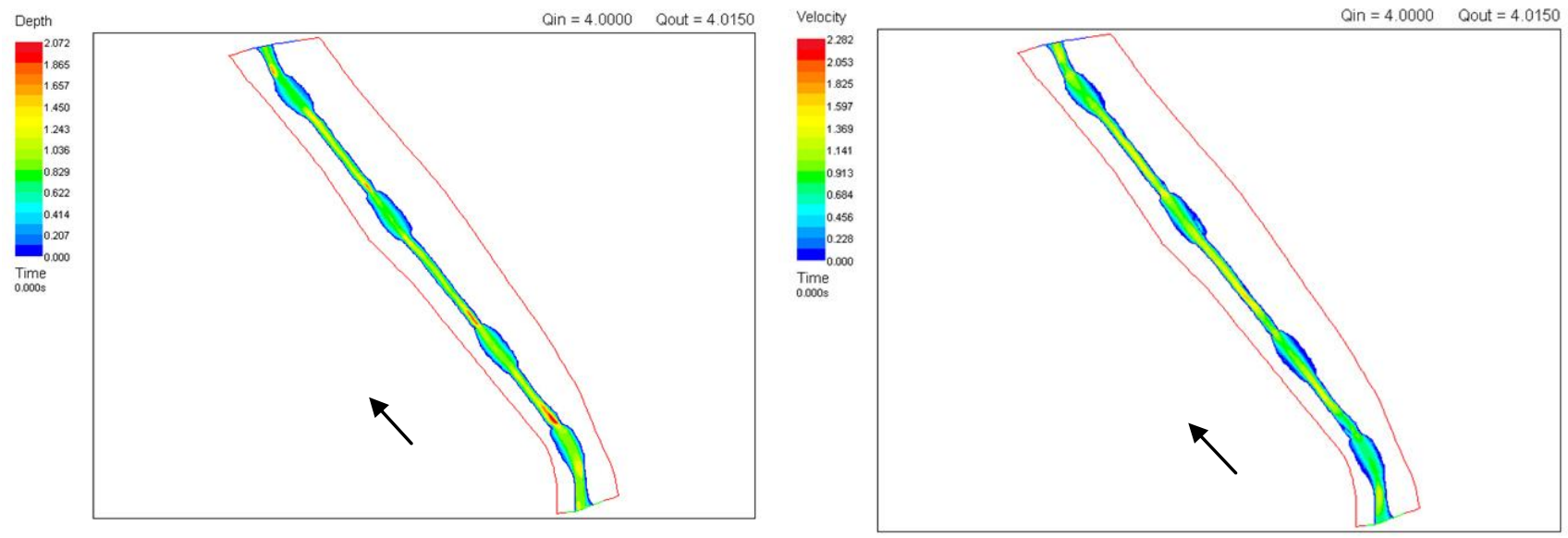

Fig. 8 

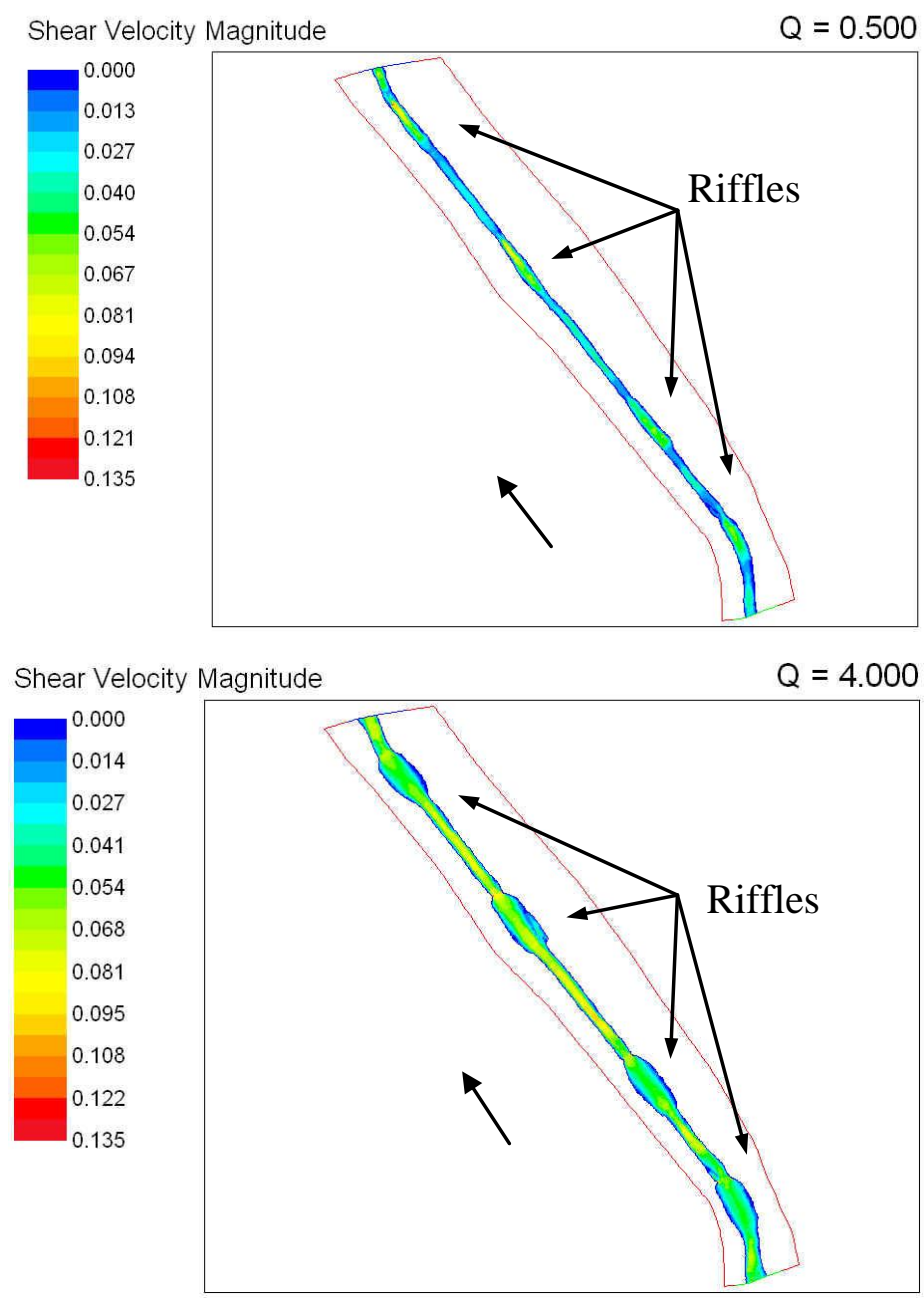

Fig. 9 


\section{a) Original Channel}

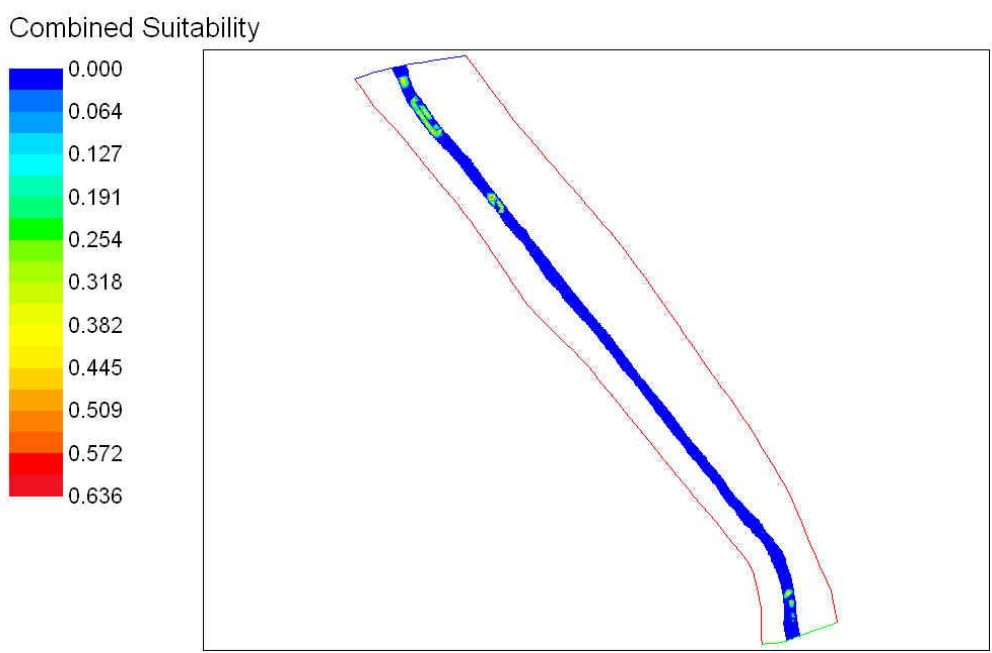

b) Design Channel

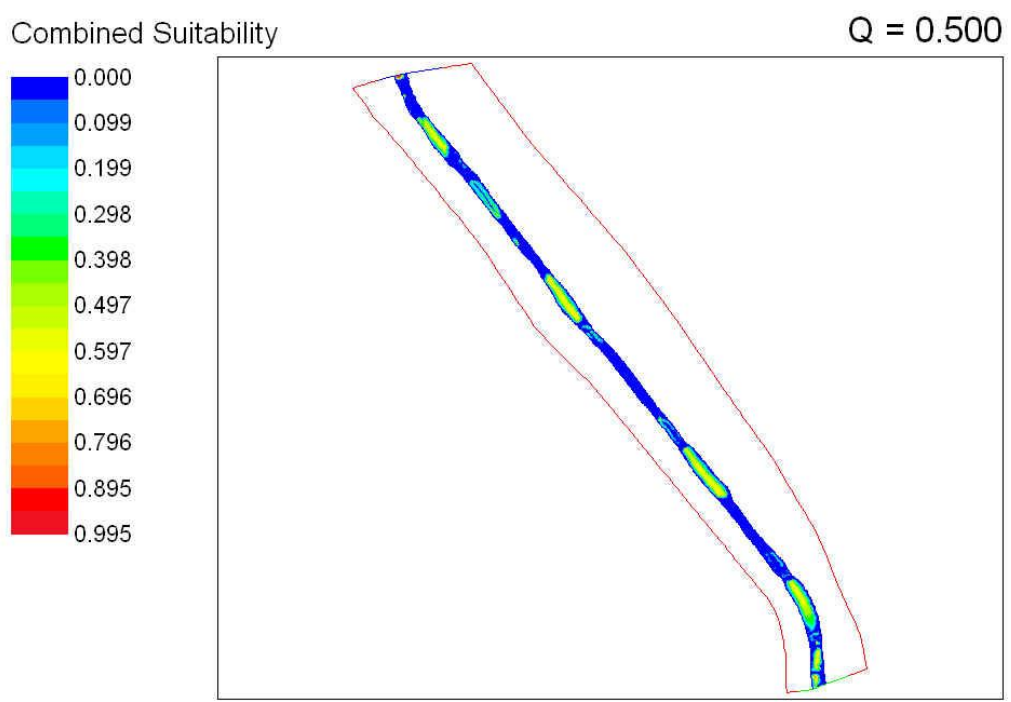

Fig. 10 


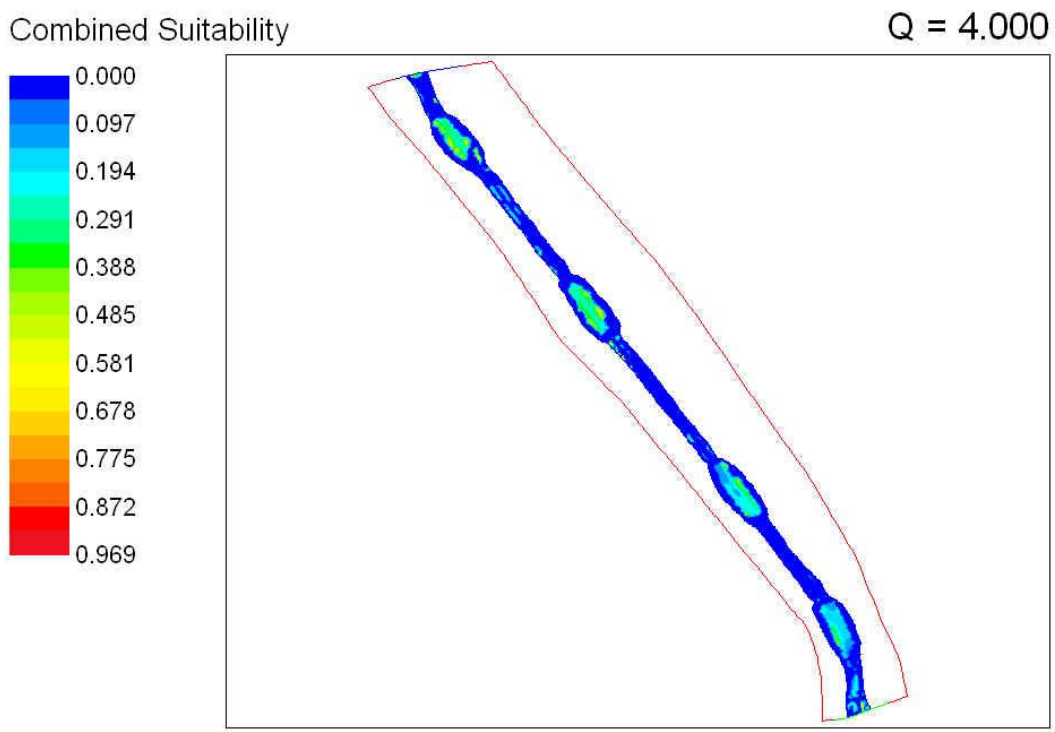

Fig. 11 


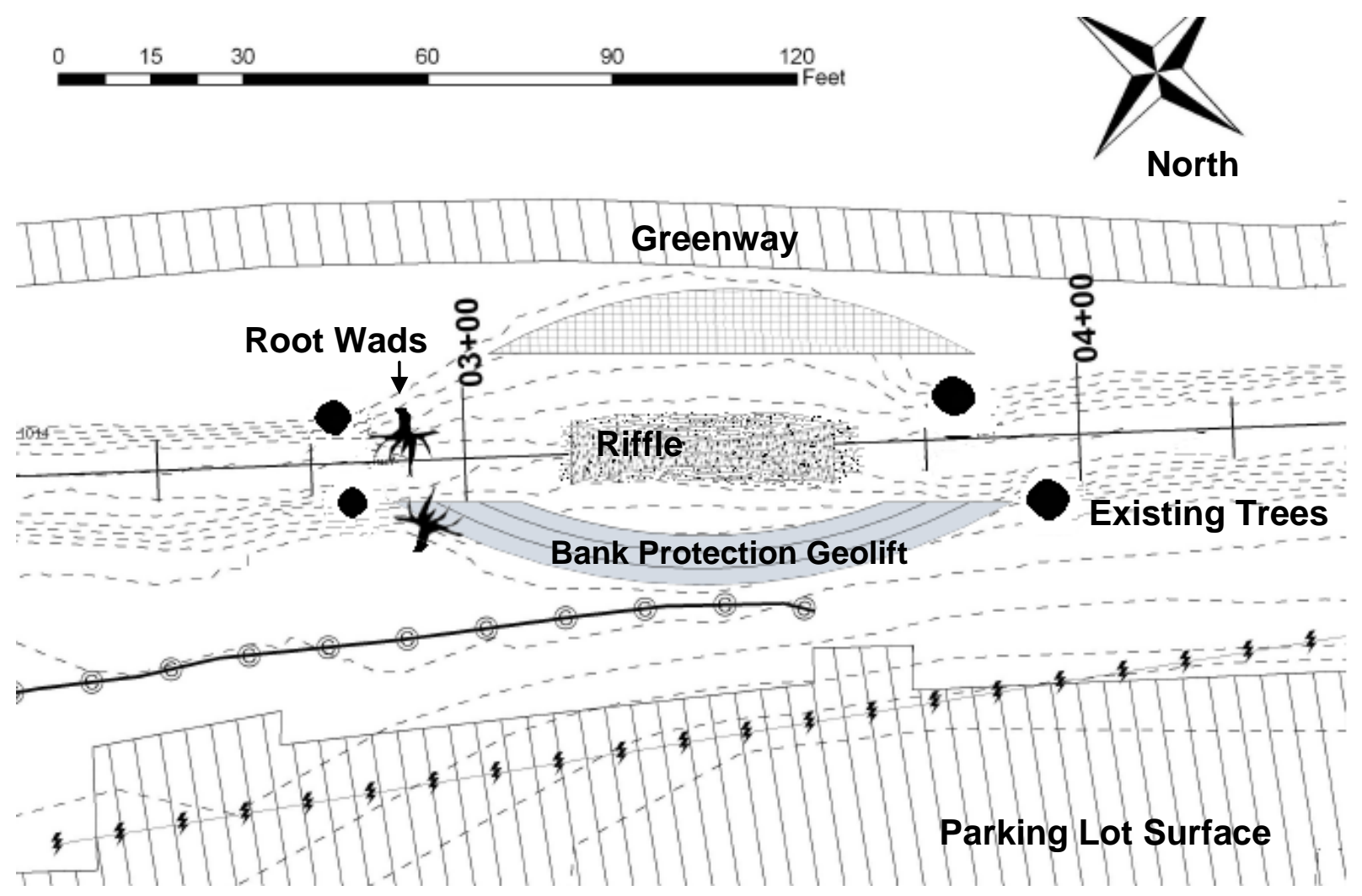

Fig. 12 


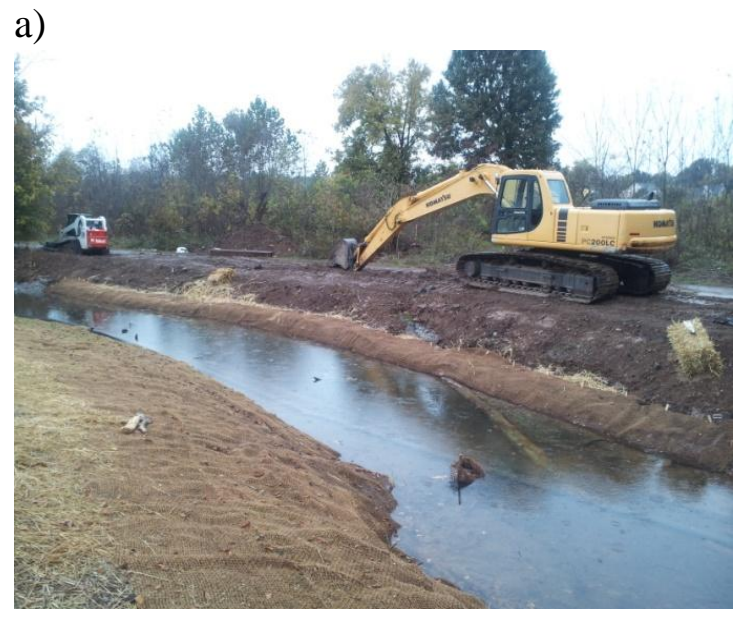

b)

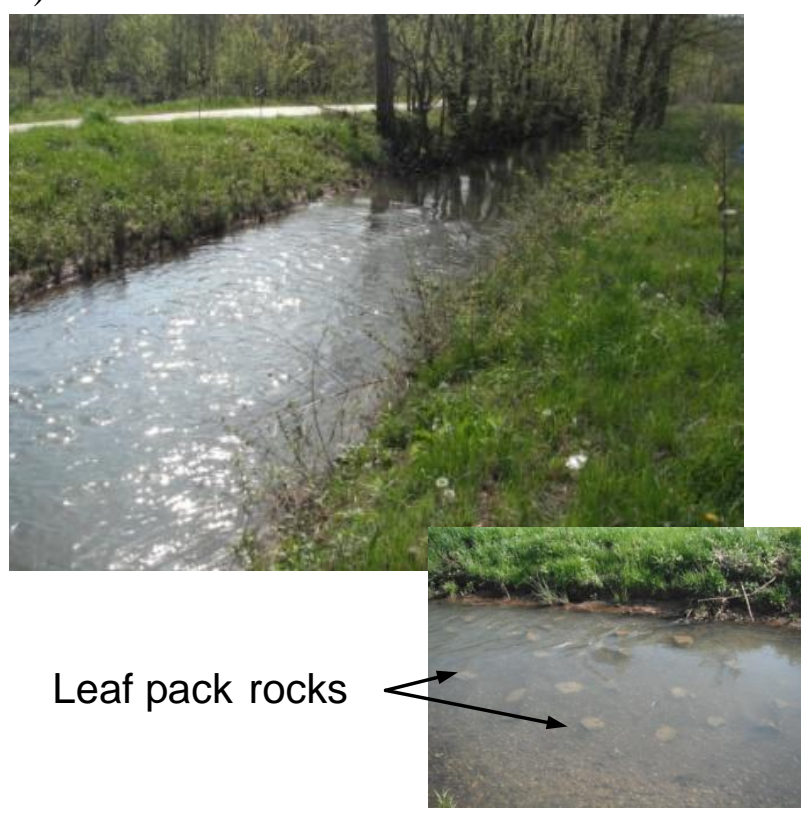

Fig. 13 

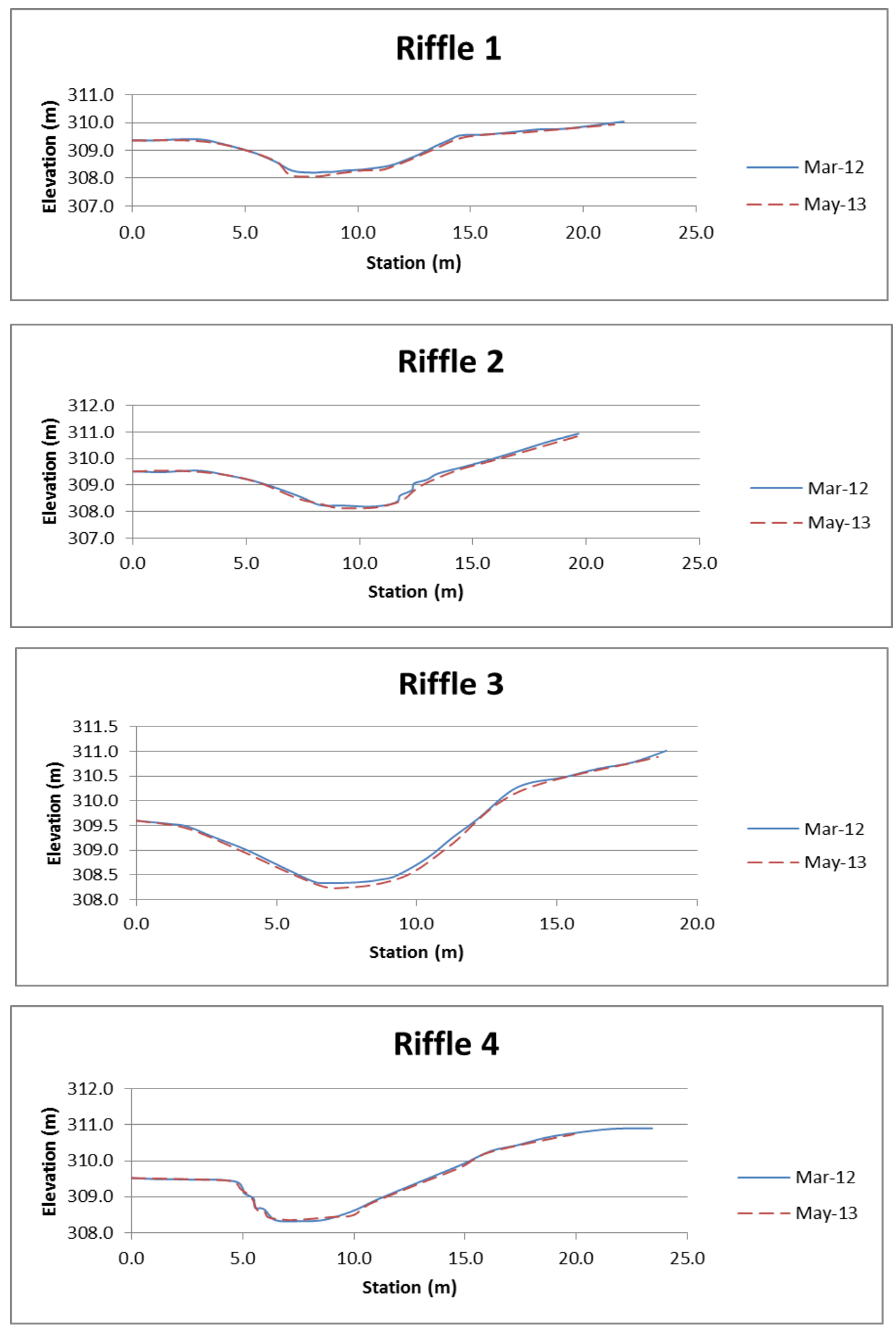

Fig. 14 

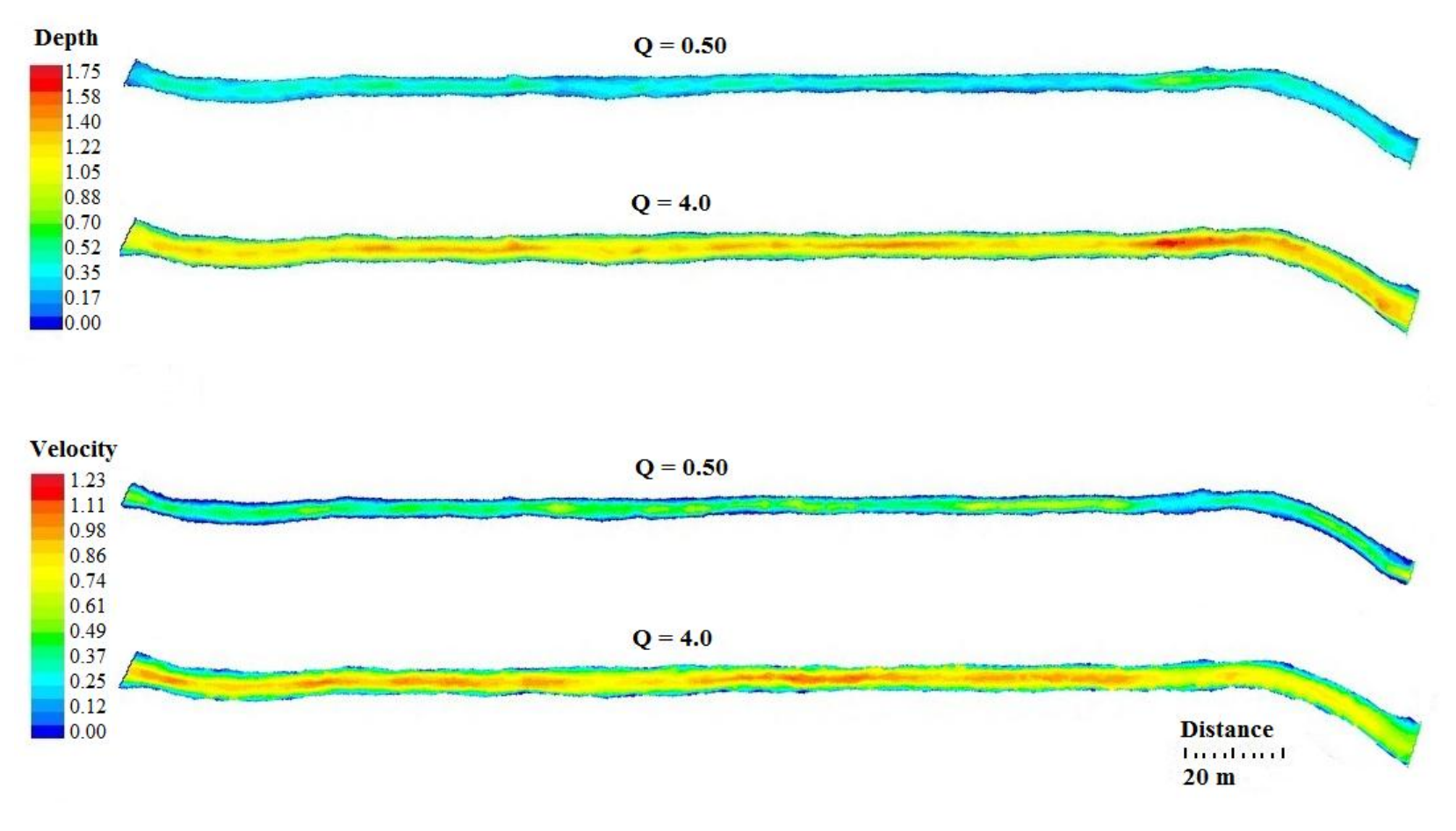

\section{Figure 7}

7

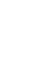
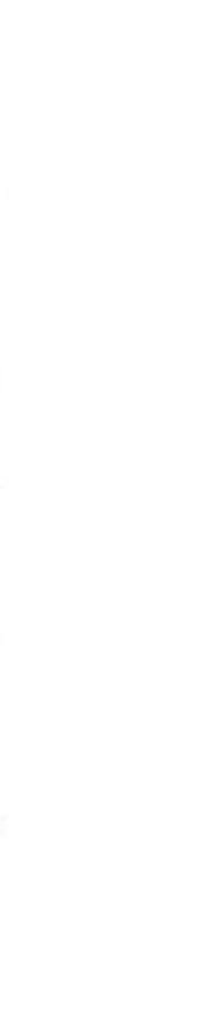


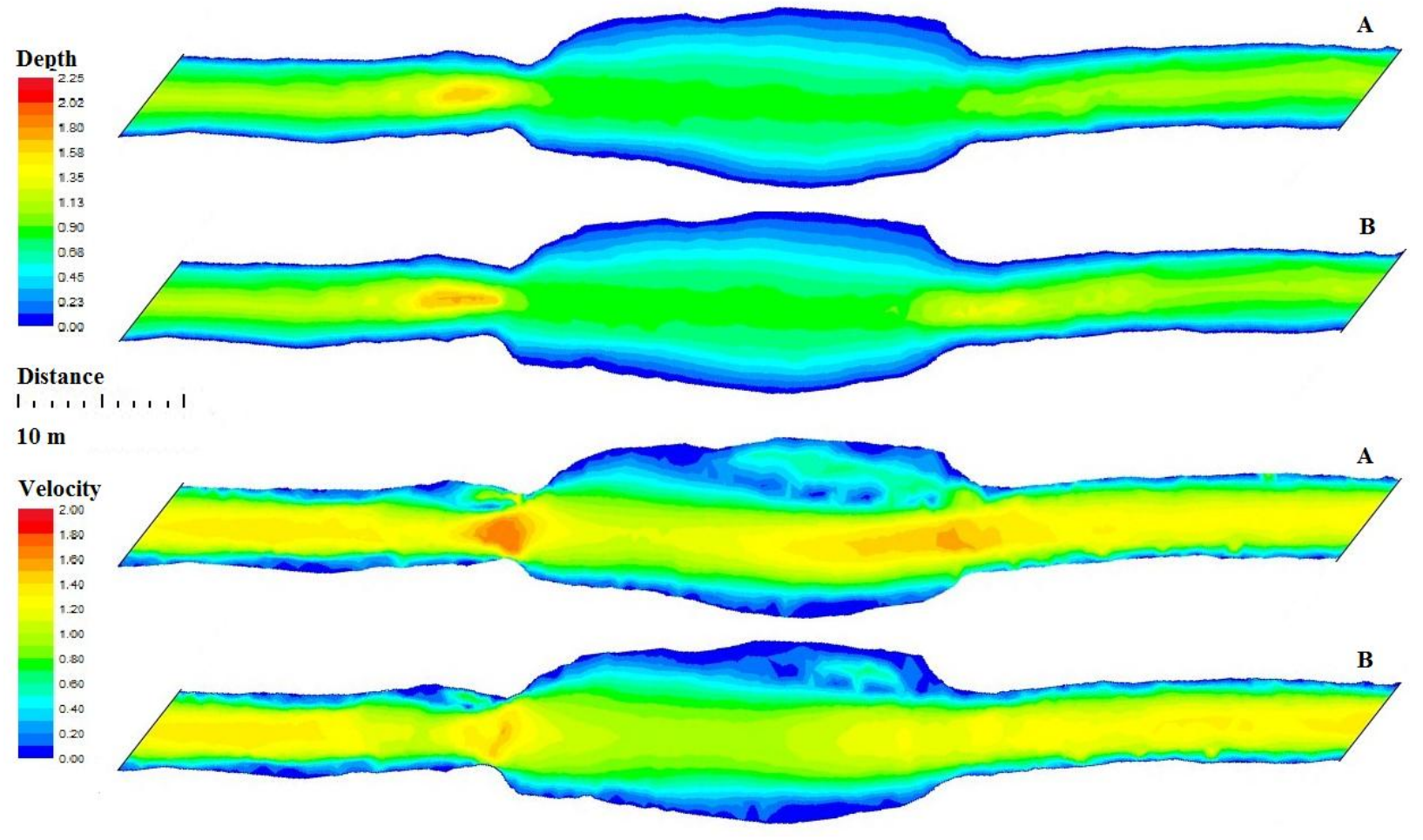




\section{List of Figures}

Fig. 1. Location map of Beaver Creek study site in Knox County, Tennessee. Aerial view from Google Earth ${ }^{\mathrm{TM}}$ (2009) with project site in red box and arrow showing creek flow direction.

Fig. 2. Photos of the 6.5-m wide incised channel showing dense woody vegetation on the banks (left) and flood flow near bankfull (right).

Fig. 3. Topographic rendering of proposed conceptual design for the constructed riffle areas forming hydraulic acceleration-deceleration-acceleration patterns. Model section approximately $104 \mathrm{~m}$ in length and bed and bank topography from site survey.

Fig. 4. Topographic image with trees as vertical cylinders used for the FLOW3D® model boundary.

Fig. 5. FLOW3D modeled maximum velocity magnitude and velocity magnitude vectors illustrated in $y-z$ cross-sections in the channel with the bank trees present.

Fig. 6. FLOW3D modeled maximum velocity magnitude and velocity magnitude vectors illustrated in $y-z$ cross-sections in the channel with the restoration design implemented.

Fig. 7. River2D model for original channel topography showing water depth (m) and velocity $(\mathrm{m} / \mathrm{s})$ for low-flow $\left(0.5 \mathrm{~m}^{3} / \mathrm{s}\right)$ and bankfull flow $\left(4.0 \mathrm{~m}^{3} / \mathrm{s}\right)$.

Fig 8. River2D model for proposed four riffles located at expanded channel width for a) an initial condition with no bed topography modifications at the riffle entrance, and b) a final design condition with deepening of the bed topography at the riffle entrance. Model discharge was bankfull flow at $\left(4.0 \mathrm{~m}^{3} / \mathrm{s}\right)$.

Fig. 9. River2D model for proposed four riffles showing shear velocity $(\mathrm{m} / \mathrm{s})$ for low-flow $(0.5$ $\left.\mathrm{m}^{3} / \mathrm{s}\right)$ and bankfull flow $\left(4.0 \mathrm{~m}^{3} / \mathrm{s}\right)$, and bed shear stress reversal between stages. 
Fig. 10. River2D model for low-flow stage $\left(0.5 \mathrm{~m}^{3} / \mathrm{s}\right)$, habitat composite WUAs for the greenside darter comparing the original channel to the design channel morphology with four riffle-pool structures.

Fig. 11. River2D model for high-flow stage $\left(4.0 \mathrm{~m}^{3} / \mathrm{s}\right)$, habitat composite WUAs for the northern hogsucker for the design channel morphology with four riffle-pool structures.

Fig. 12. Plan view of final riffle design constructed at the study site. Topography contour intervals are $2-\mathrm{ft}$.

Fig. 13. Site photos of a) riffle under construction in October 2010, and completed riffle after one-year following construction completion in April 2012.

Fig. 14. Post-construction monitoring for channel stability at riffle cross-sections conducted in March 2011 and April 2012. 


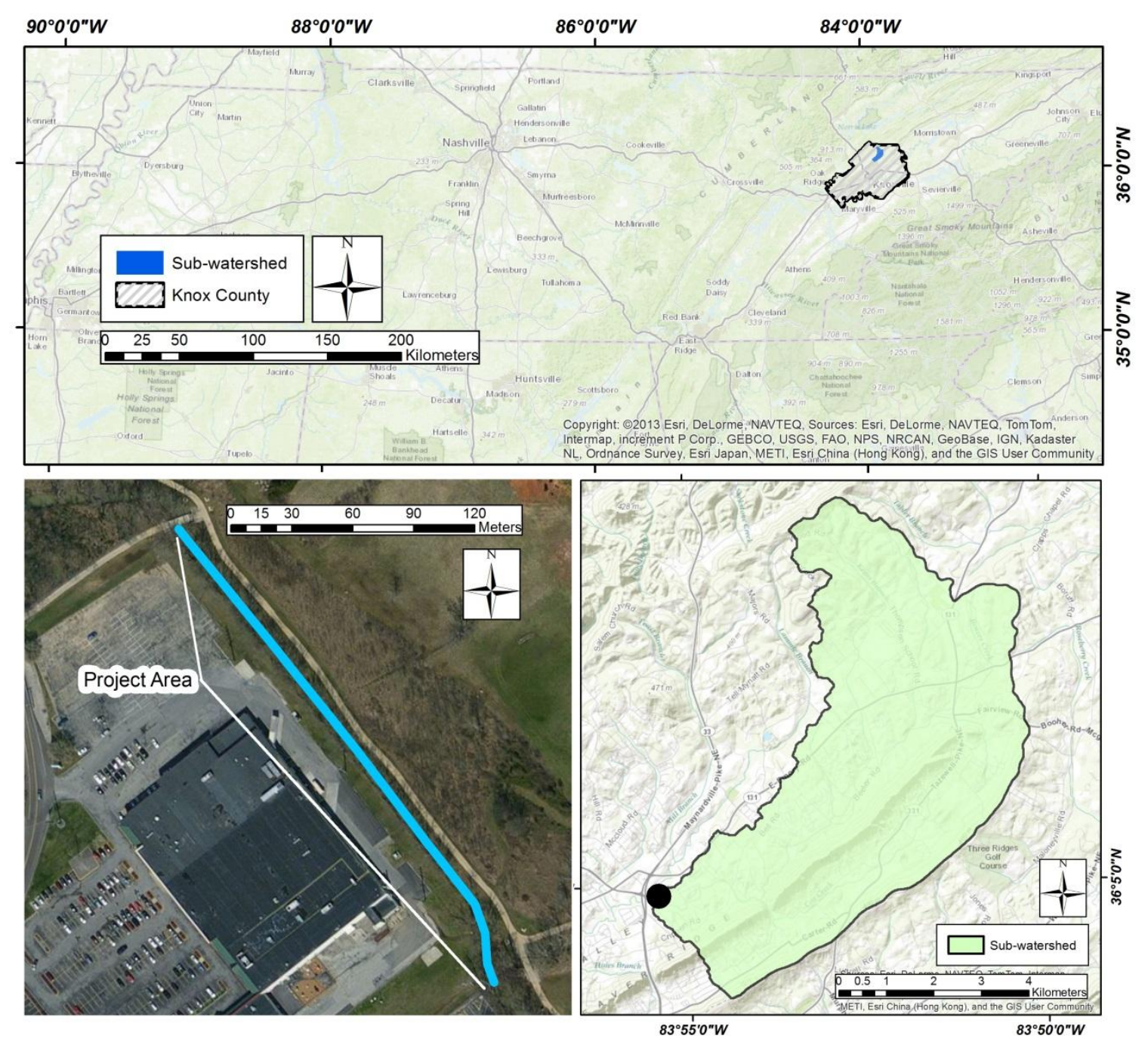

Fig. 1 

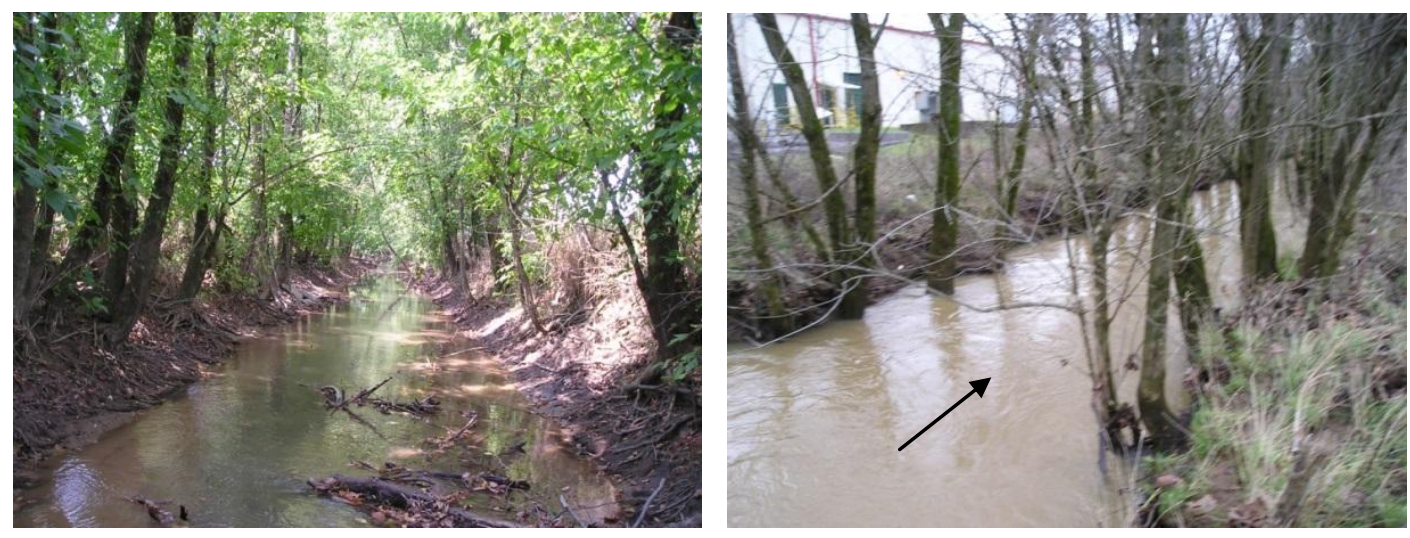

Fig. 2

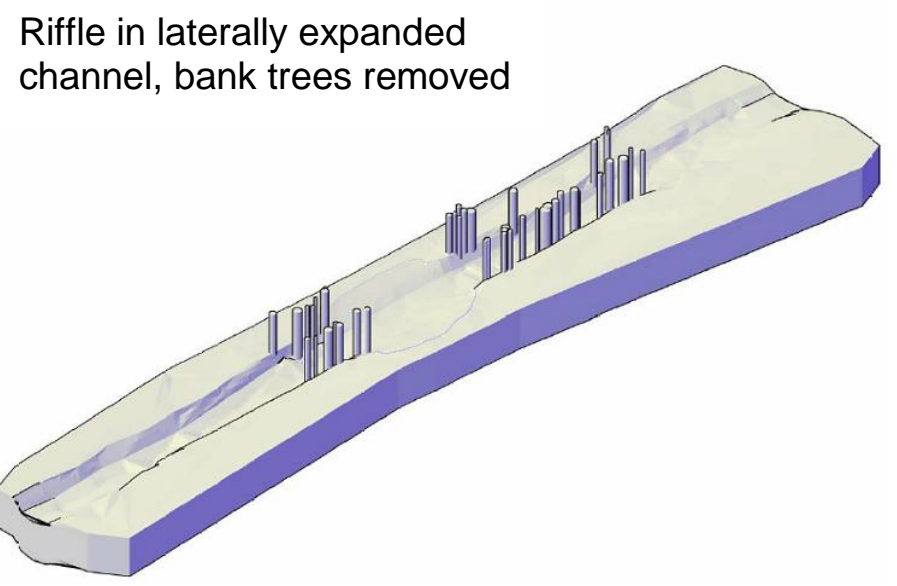

Fig. 3 


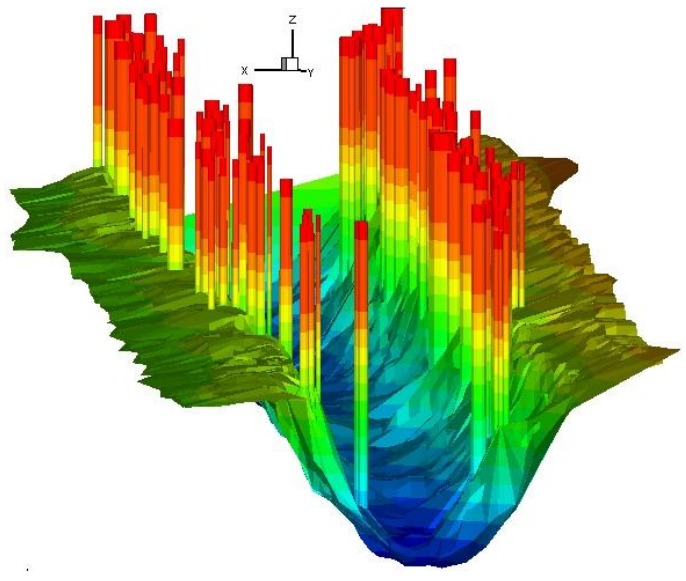

Fig. 4 

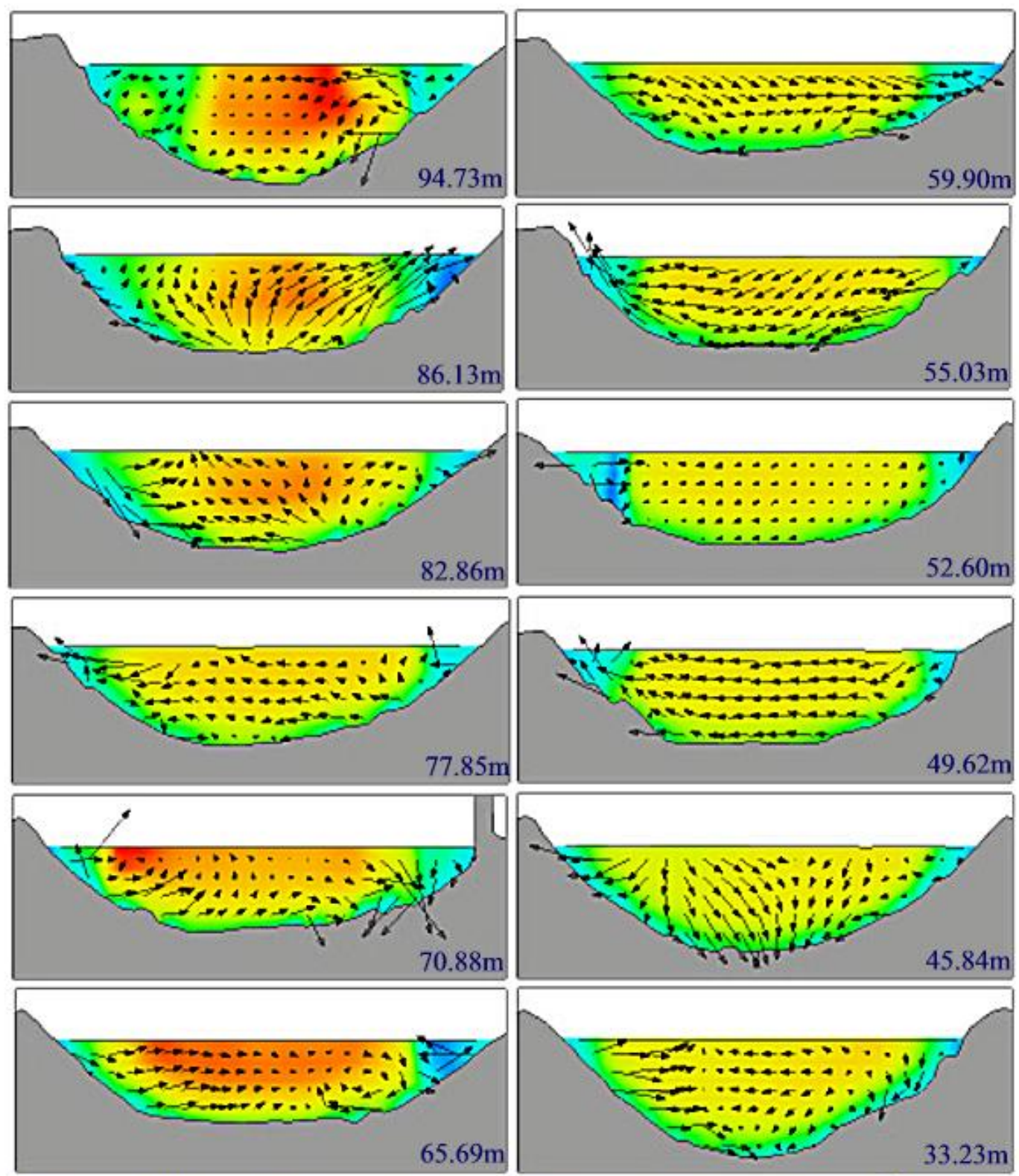

\begin{tabular}{|l|llllllll}
0.000 & 0.100 & 0.200 & 0.300 & 0.400 & 0.500 & 0.600 \\
\hline
\end{tabular}

Fig. 5 

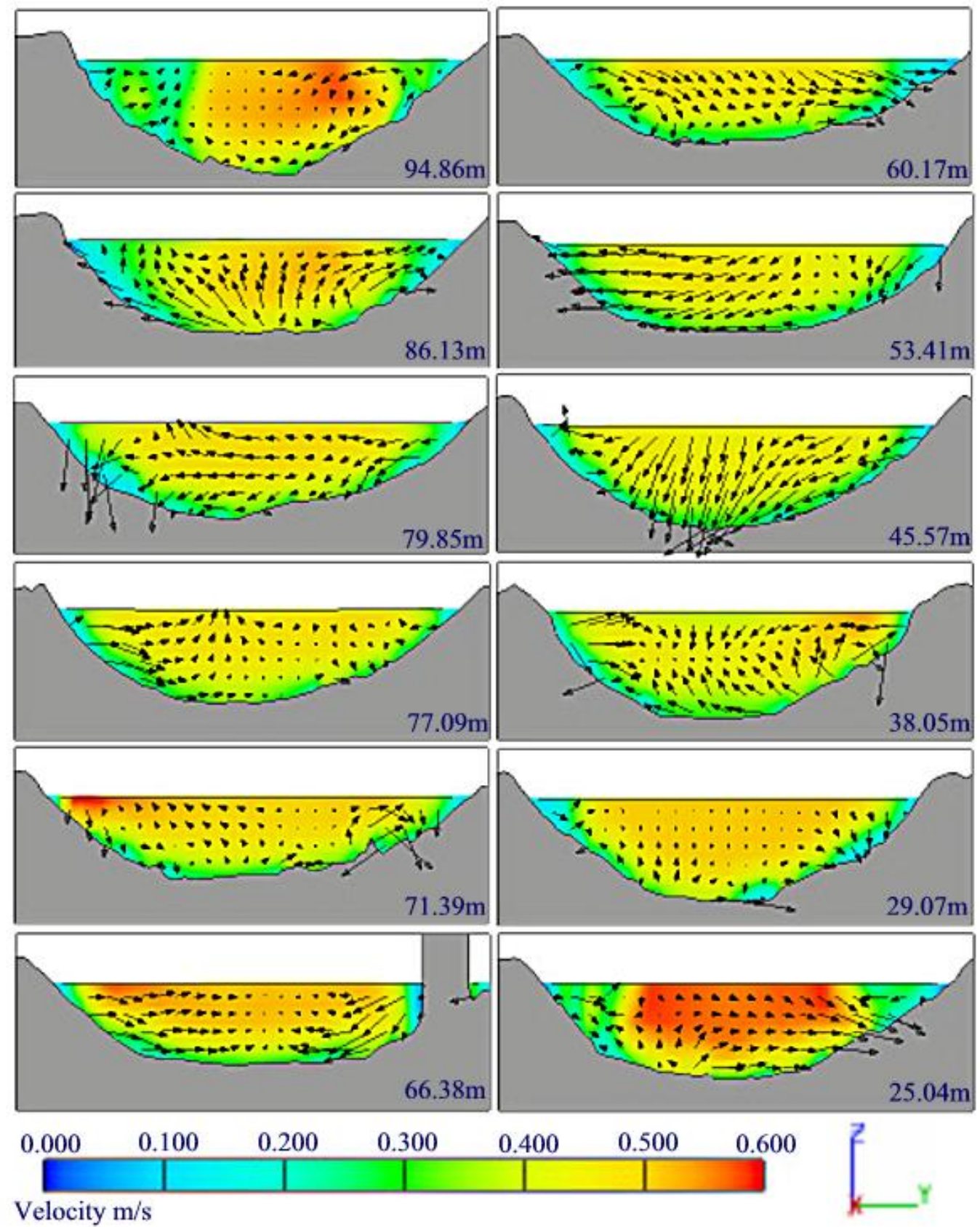

Fig. 6

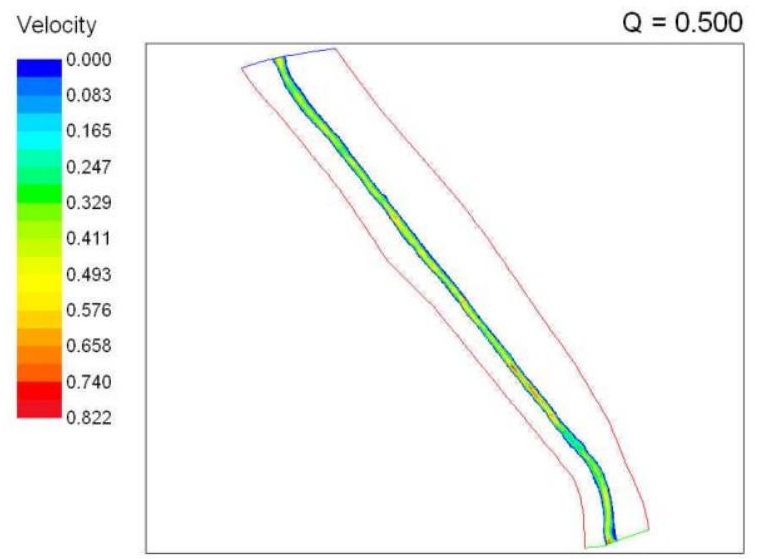




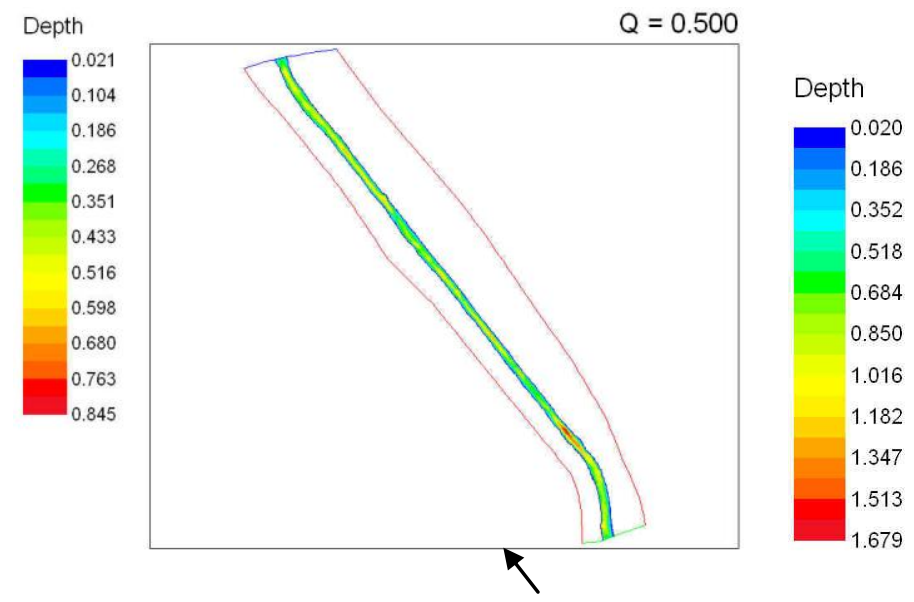

Velocity

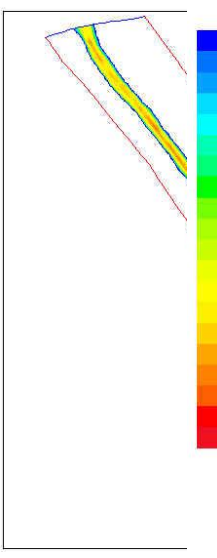

$Q=4.000$

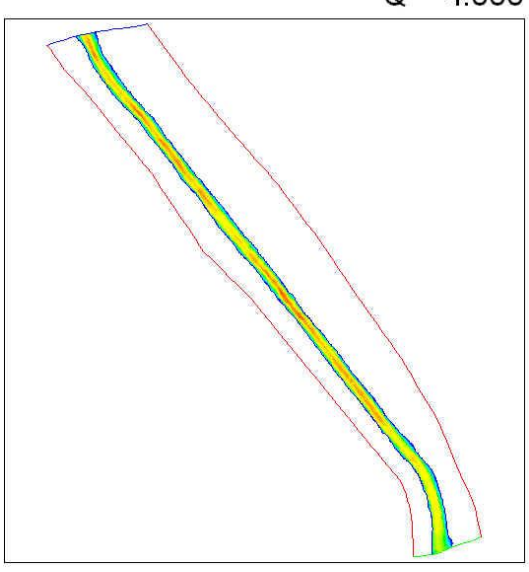

Fig. 7 
a)
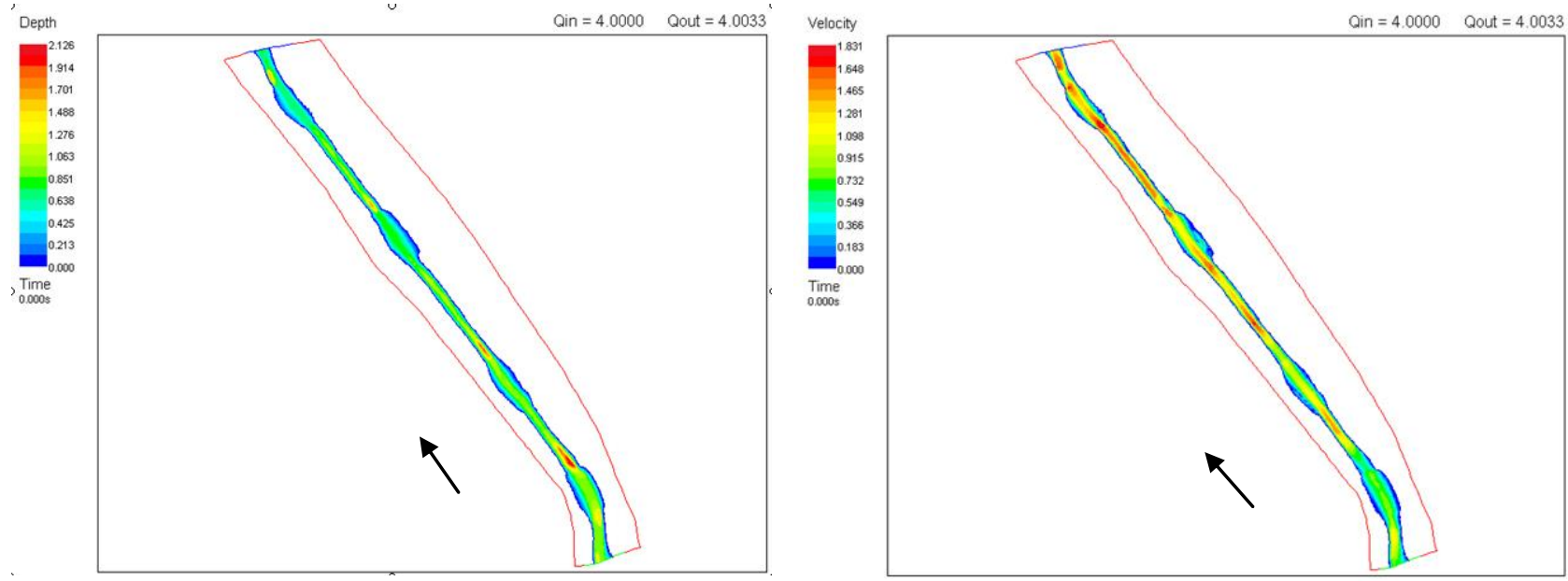

b)
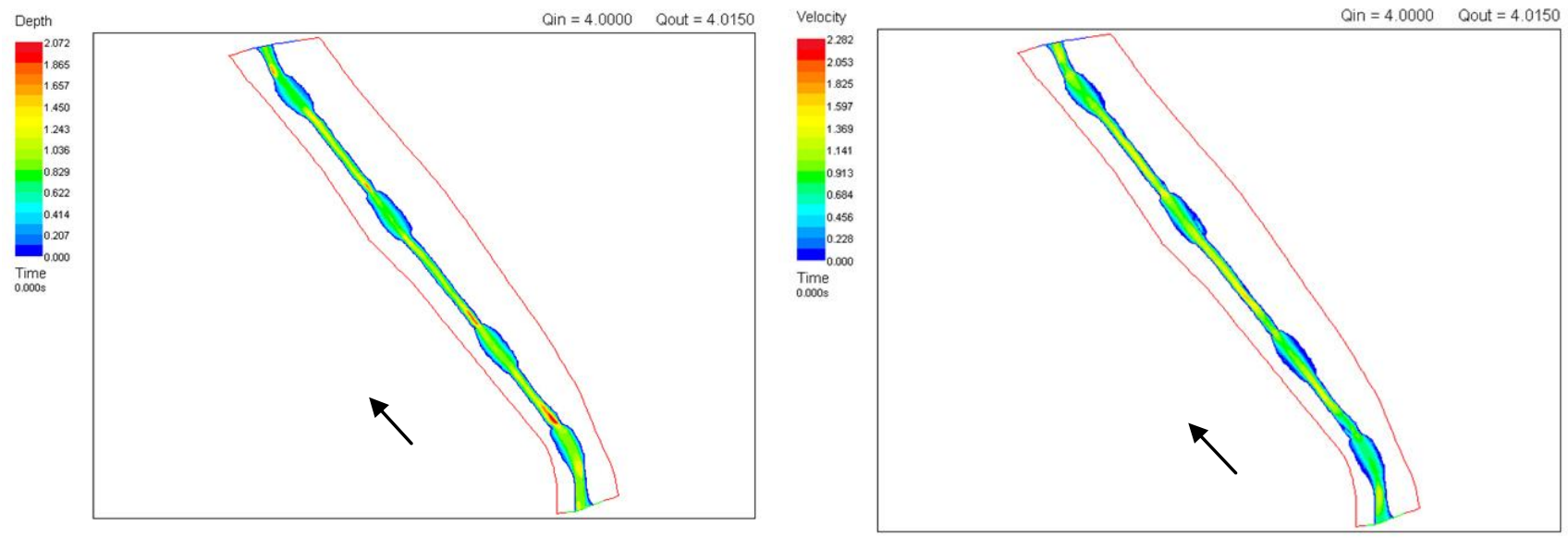

Fig. 8 

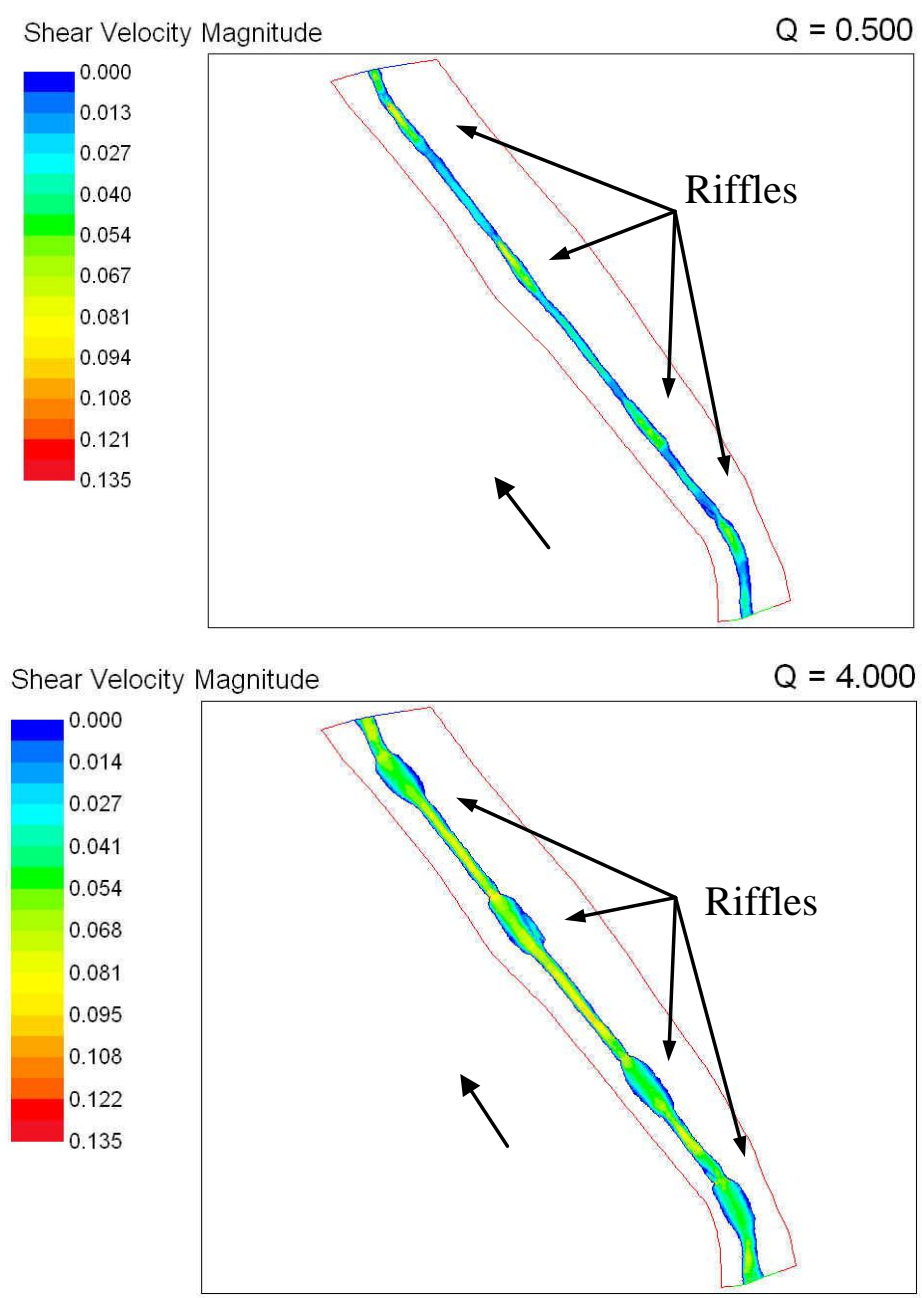

Fig. 9 


\section{a) Original Channel}

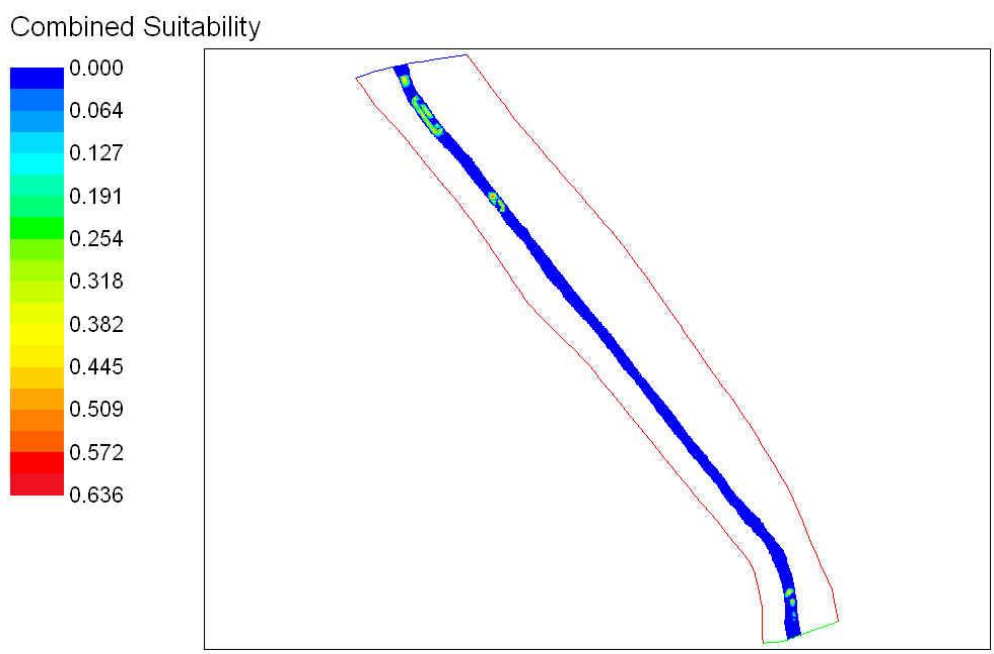

\section{b) Design Channel}

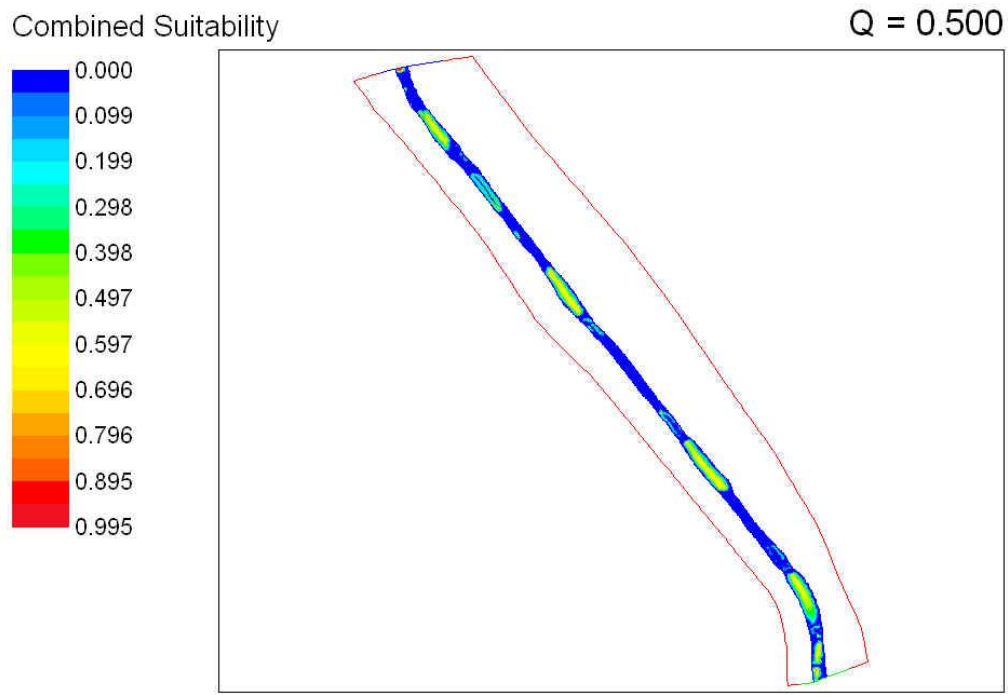

Fig. 10 


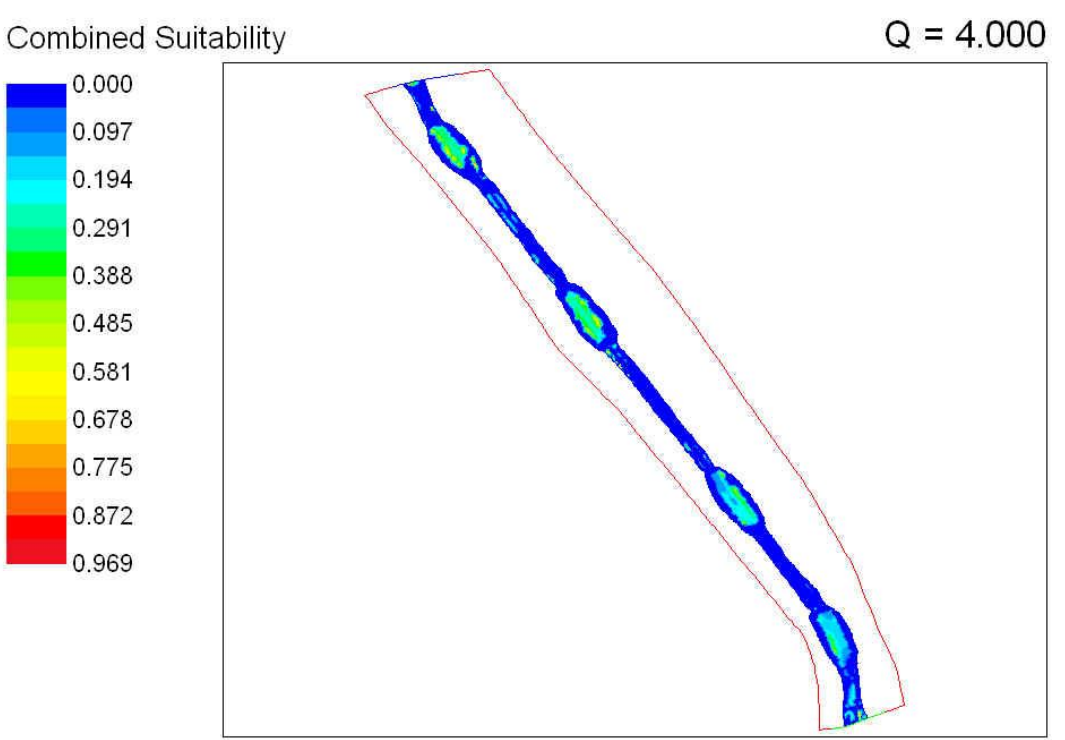

Fig. 11 

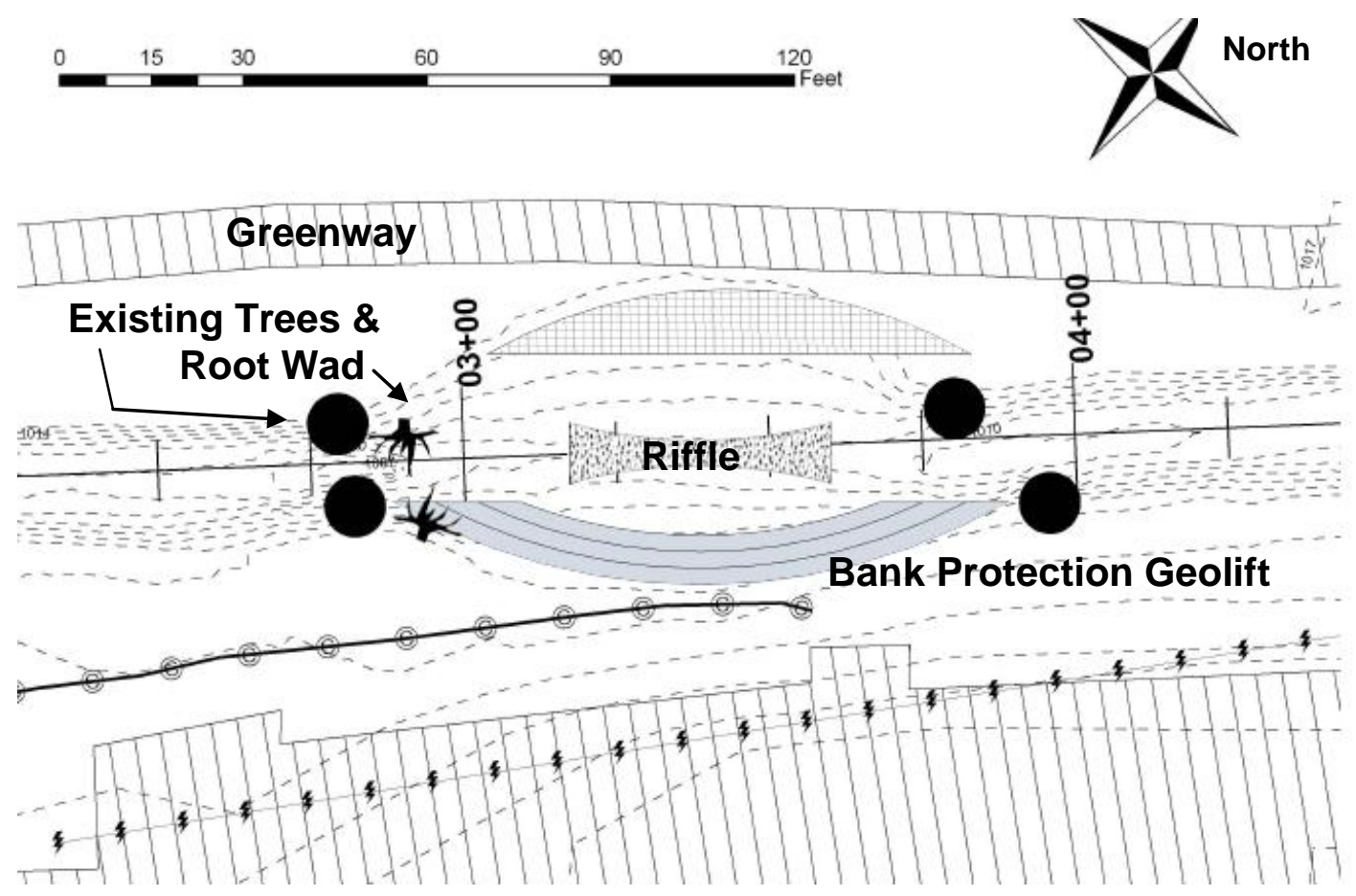

Fig. 12 
a)

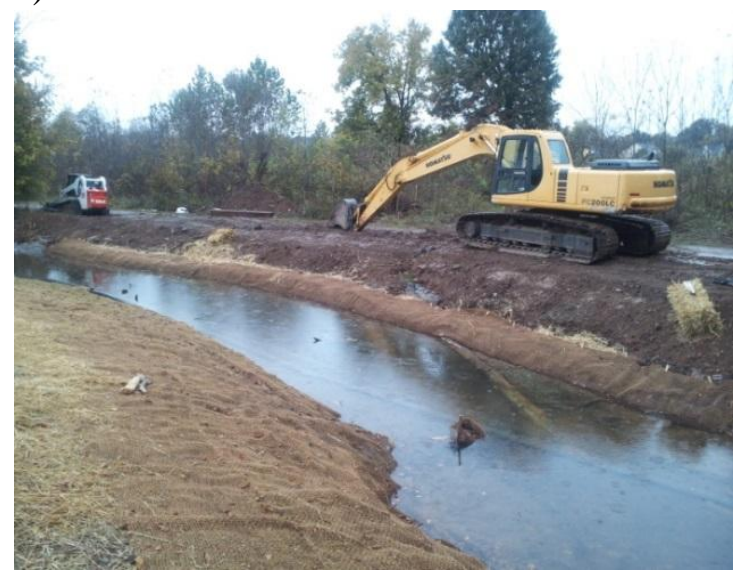

b)

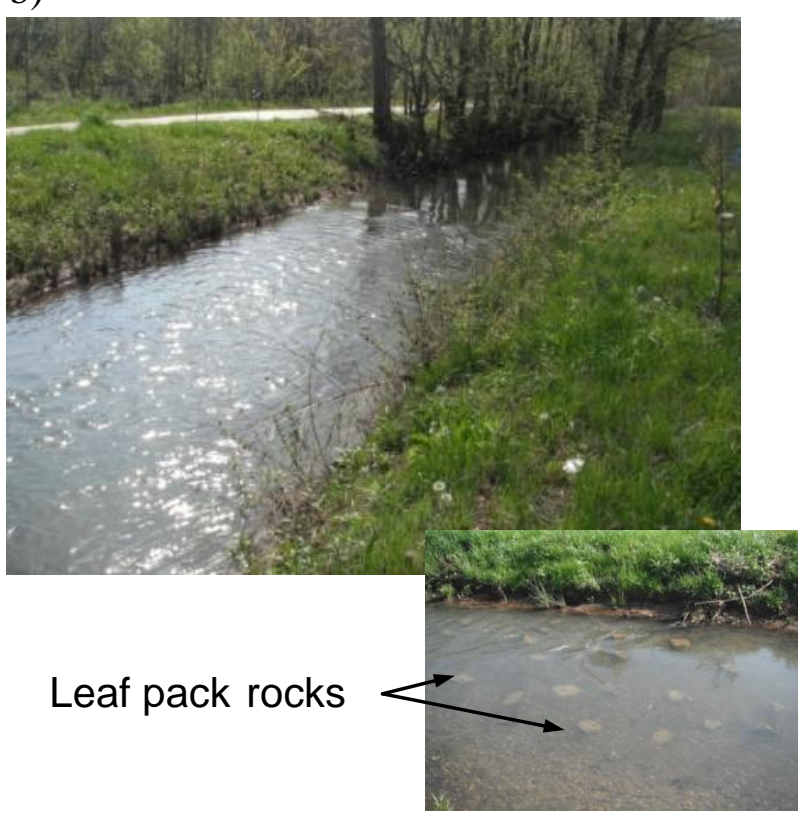

Fig. 13 

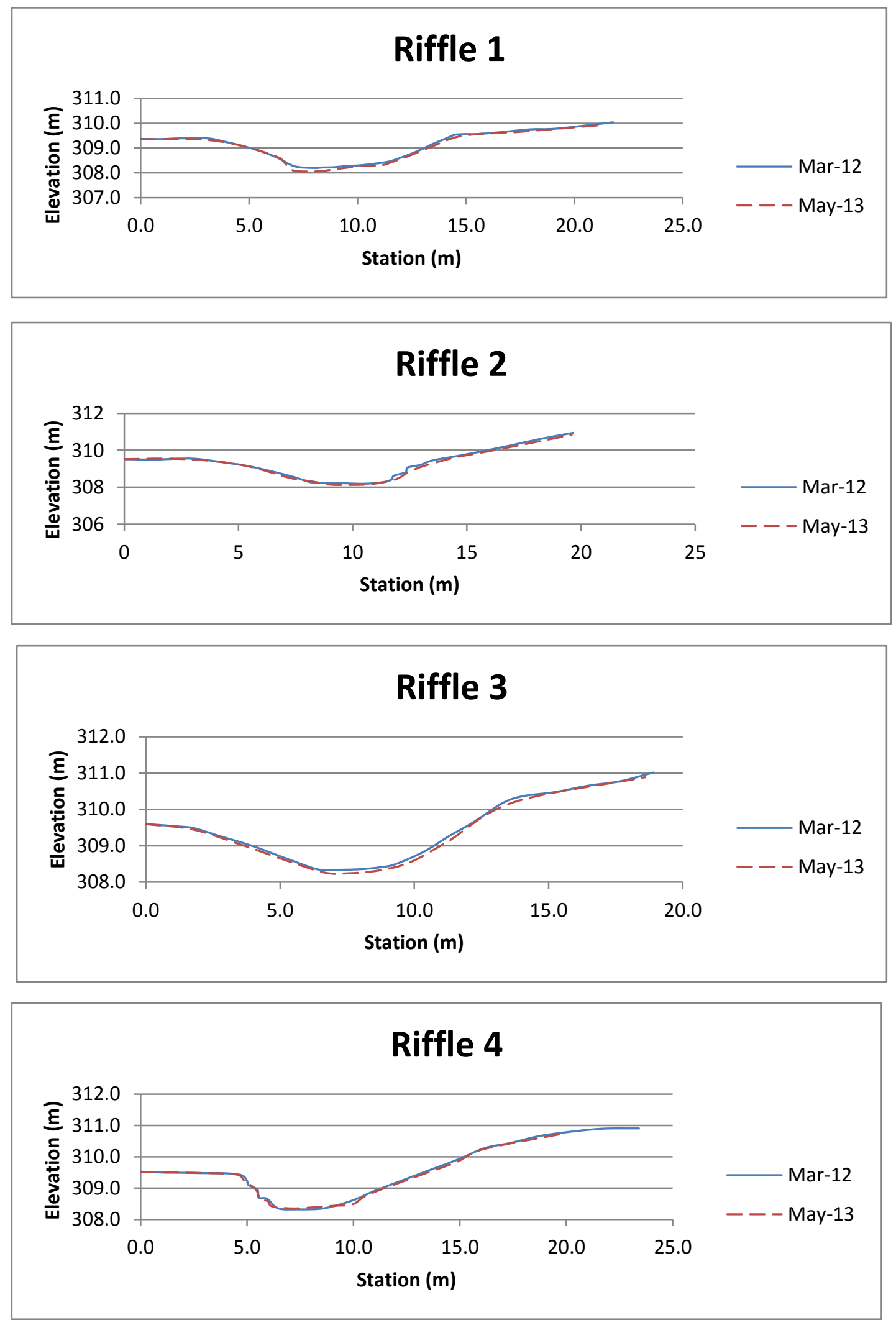

Fig. 14 
Figure
Click here to download Figure: Figure_7+8_R2.docx
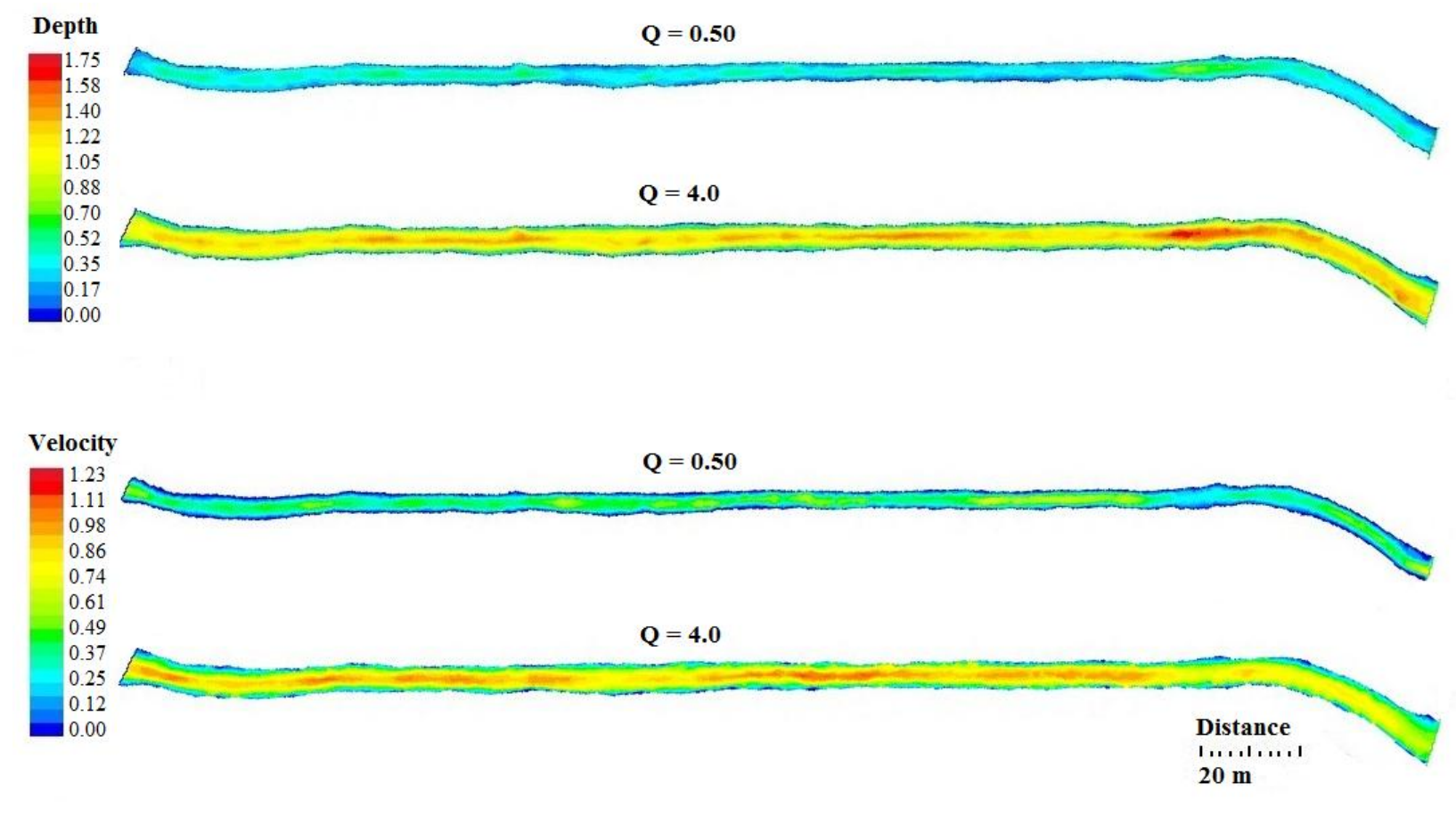

Figure 7

Revised May 2014 


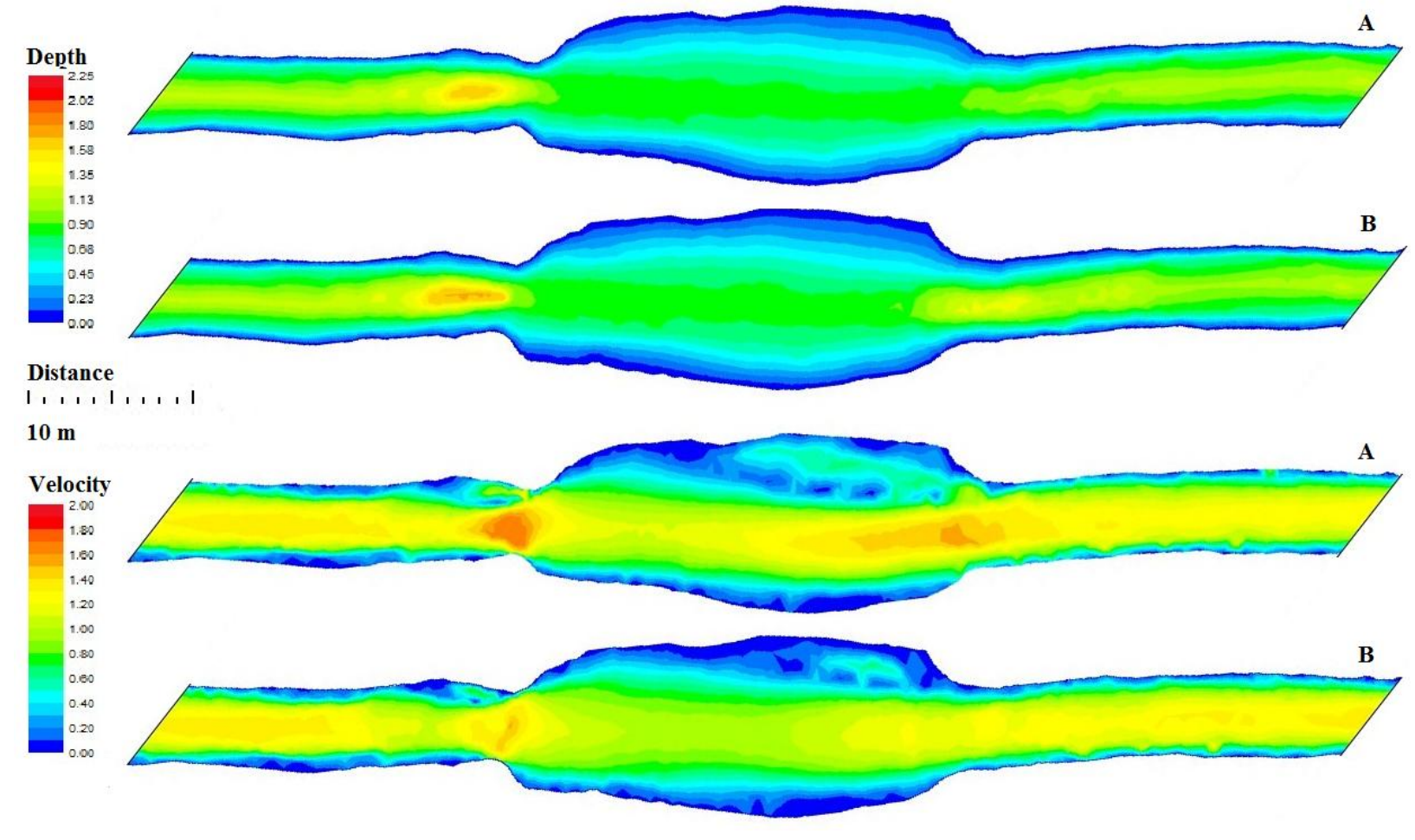

Figure 8

Revised May 2014 


\section{Tables}

Table 1. Habitat composite WUAs for low-and high-flow stages comparing the original channel to the design channel morphology with four riffle-pool structures. Three fish species used in the River2D model were: rock bass, greenside darter, and northern hogsucker.

\begin{tabular}{lcccc} 
Channel & Discharge & \multicolumn{3}{c}{ Weighted Usable Area $\left(\mathbf{m}^{2}\right)$} \\
\cline { 3 - 5 } Morphology & $\left(\mathrm{m}^{3} / \mathrm{s}\right)$ & Rock Bass & Greenside Darter & Northern Hogsucker \\
\hline Original Channel & 0.5 & 17.7 & 34.8 & 318.6 \\
Design Channel & 4.0 & 11.7 & 164.4 & 419.6 \\
\hline Original Channel & 0.5 & 2.7 & 7.5 & 487.7 \\
Design Channel & 4.0 & 6.8 & 132.3 & 714.0 \\
\hline
\end{tabular}

Table 2. Benthic macroinvertebarte sampling for pre- and post-construction periods.

\begin{tabular}{cccccccc}
\hline & $\begin{array}{c}\text { Index } \\
\text { Scores }\end{array}$ & & & & & & \\
Survey Date & TotTaxa & EPTTax & \%ClingP & \%EPT-Cheum & \%OC & NCBI & \%TNUTOL \\
\hline Jul-09 & 21 & 3 & 45.1 & 16 & 38.3 & 5.68 & 64.2 \\
Aug-12 & 21 & 6 & 71.43 & 27.27 & 17.75 & 5.39 & 52.38 \\
Aug-13 & 27 & 6 & 51.98 & 20.79 & 57.92 & 5.18 & 45.05 \\
Trend & + & + & & + & - & + & + \\
\hline
\end{tabular}

Table 3. Fish IBI sub-index site surveys for pre- and post-construction periods.

\begin{tabular}{lccc}
\hline & $1 / 7 / 2010$ & $9 / 18 / 2013$ & \\
& Score & Score & Trend \\
\hline Number of native fish species & 10 & 16 & + \\
Number of darter species & 3 & 4 & + \\
Number of Sunfish species (excl. Micropterus) & 1 & 3 & + \\
Number of sucker species & 1 & 1 & \\
Number of intolerant species & 2 & 2 & \\
Percent tolerant species & $1 \%$ & $6.7 \%$ & - \\
Percent omnivores and stoneroller species & $20 \%$ & $30.8 \%$ & - \\
Percent specialized insectivores & $54 \%$ & $46.0 \%$ & - \\
Percent piscivores & $7 \%$ & $2.9 \%$ & - \\
Catch Rate (per 300 sq. ft.) & $4 \%$ & na & \\
Percent hybrids & $0 \%$ & $0 \%$ & \\
Percent anomolies & $1 \%$ & $0 \%$ & \\
\hline
\end{tabular}

